\title{
WHAT COMES TO MIND WHEN YOU HEAR THE WORDS "NUCLEAR WASTE REPOSITORY"? \\ A STUDY OF 10,000 IMAGES
}

\author{
Prepared by: \\ Paul Slovic, Mark Layman, and James H. Flynn \\ Decision Research
}

November, 1990

Prepared for:

Nevada Agency for Nuclear Projects

Yucca Mountain Socioeconomic Project

Phase IV-B, Tasks 8.5 and 8.6 


\section{Summary}

Attempts by the federal government and the nuclear industry to develop sites for disposal of high-level and low-level radioactive wastes have been stymied by public and political opposition The record of strenuous protest against nuclear waste repositories, as well as the findings of numerous public opinion surveys, make it clear that public opposition is widespread and deeply felt. It is also clear that there is an immense gap between the perceptions of the public and the views of technical experts and nuclear-industry officials.

Given the seriousness of nuclear waste as a public issue, it is surprising that there have been only a few attempts to understand the deeper meaning of nuclear fears and opposition to nuclear waste disposal sites, and to provide some insight into the nature and pervasiveness of people's concerns. One step toward a deeper understanding would be to define the origins of these concerns, the emotions and images that underlie them, and their tractability or stability over time.

We focus, in this study, on the imagery associated with a nuclear waste repository. The idea that images and perceptions influence people's attitudes and behaviors has a long history, going back to the origins of western civilization. More recently, a number of psychologists have held that images are organized and structured in much the same ways as perceptions, beliefs and attitudes. Images are often accompanied by affect and these affectladen images have been found to have important behavioral consequences.

In earlier research, we used the "method of continued associations" to document the relationship between word-association images and important economic behaviors. The results showed that cities and states had diverse positive and negative images that persisted over time, and that these images were predictive of people's stated preferences for vacation, 
retirement and business sites. Image quality was also found to be related to past and future vacation visits. These findings have documented scientifically what manufacturers, entertainers, politicians, advertisers, and public relations specialists have presumed for a long time--images and perceptions exert powerful effects upon human behavior.

In the present study, we recorded 10,000 word-association images from more than 3,300 respondents to four surveys during the period between April, 1988 and January 1, 1990. Following the general method outlined by Szalay and Deese for collecting "continued associations" image data were collected from these respondents based upon the stimulus term "underground nuclear waste repository."1 Images were collected from a Nevada State sample, including oversamples for Nye, Lincoln and Esmeralda Counties, from the Phoenix metropolitan area, from Southern California and from a national sample. Response rates were high (72 percent to 84 percent) in each survey.

Each of the 10,000 images was assigned to one of thirteen general or superordinate categories, which expressed the dominant theme of the response. All but one superordinate categories contained subordinate categories. All in all there were 92 distinct categories. The two dominant superordinate categories, (1) Negative Consequences and (2) Negative Concepts accounted for more than 56 percent of the total number of images. Many of the smaller categories and subcategories were also quite negative in tone. The five leading subordinate categories, Dangerous/Toxic, Death/Sickness, Environmental Damage, Bad, and Scary, accounted for more than $42 \%$ of the total number of images.

1 The stimulus phrase for one study was, "underground nuclear waste storage facility." 


\section{Summary - What Comes to Mind / iii}

Positive imagery was indeed rare. Category XII, Positive, accounted for only one percent of the images ( 97 images out of 10,000 ). Other generally positive categories such as Necessary, Employment, and Money/Income combined for only 2.5 percent of the images.

Jones et al. (1984) have attempted to characterize the key dimensions of stigma, a concept that has been applied to places with adverse environmental characteristics. Two of their major defining characteristics of stigma are peril and negative aesthetic qualities (ugliness, repulsion). These qualities dominate the repository images.

The results are similar for each of the separate survey samples. Close examination of the categories by sample shows that (a) there are differences in some image frequencies from one sample to another, but (b) these differences are quite small and do not change the interpretations in any important way.

The negativity of repository images is remarkably consistent across people of different ages, incomes, education levels, and political persuasions. Women were slightly more likely to rate their images as negative than were men; people aged 65 or older were somewhat more likely to rate their images as positive, as were people who reported their political orientation as very conservative. None of these differences were large.

The information in these image data appears to go well beyond what was obvious or expected on the basis of previous research or the record of public opposition to nuclear waste facilities. These images demonstrate an aversion so remarkably strong that to call it "negative" or a "dislike" hardly does it justice. What these images reveal are pervasive qualities of dread, revulsion, and anger; the raw materials of stigmatization and political opposition. Images pertaining to potential benefits, necessity, and scientific or technical 


\section{Summary - What Comes to Mind / iv}

progress are simply overwhelmed by the negative responses. Concerns by repository proponents that a nuclear waste facility might be adversely perceived if labeled a "dump" clearly misjudge the nature of public images; dumpsite imagery would appear almost positive in comparison to the more prevalent responses.

Nuclear waste exists and must be dealt with. This analysis of 10,000 images shows that a majority of the American public is repulsed by the concept of a nuclear waste repository. The perceptions and emotions associated with a repository are psychologically, politically, socially, and economically important. In particular, the mechanisms of the human mind make it quite possible that places that become repositories for nuclear waste will also become stigmatized through associations with that dread substance. Decisions regarding the siting and management of nuclear waste must be sensitive to these perceptions and emotions and to the lack of trust that underlies them. 


\section{WHAT COMES TO MIND WHEN YOU HEAR THE WORDS "NUCLEAR WASTE REPOSITORY"? A STUDY OF 10,000 IMAGES}

"Words are the images of things."--Simonides, 500 B.C.

\subsection{Introduction}

This paper is about the images and perceptions associated with a nuclear-waste repository in the minds of the American public. It is no longer news that the public perceives radioactive wastes as exceedingly dangerous. More than a decade of strenuous public opposition to government plans to site disposal facilities for both high-level and lowlevel wastes make this clear, as do numerous public opinion surveys (Flynn, et al., 1990; Kraft \& Dunlap, in press; Kunreuther, Desvousges, \& Slovic, 1988; Nealey \& Hebert, 1983). It is also clear that there is an immense gap between the perceptions of the public and the views of technical experts and nuclear-industry officials. ${ }^{1}$

1 The following comments, from three prominent nuclear experts, appear typical of the industry and expert viewpoint on nuclear waste disposal.

"Several years ago ... I talked with Sir John Hill, ... chairman of the United Kingdom's Atomic Energy Authority. 'I've never come across any industry where the public perception of the problems is so totally different from the problems as seen by those of us in the industry ...,' Hill told me. In Hill's view, the problem of radioactive waste disposal was, in a technical sense, comparatively easy."

Luther Carter (1987, p. 9)

"Nuclear wastes can be sequestered with essentially no chance of any member of the public receiving a non-stochastic dose of radiation. ... Why then is the waste problem the Achilles' heel of nuclear energy? ... Why is the public's perception of the nuclear waste issue at such odds with the experts' perception?"

Alvin Weinberg (1989, pp. 1-2)

"The fourth major reason for public misunderstanding of nuclear power is a grossly unjustified fear of the hazards from radioactive waste.... Often called an 'unsolved problem,' many consider it to be the Achilles' heel of nuclear power. Seven states now have laws prohibiting construction of nuclear power plants until the waste disposal issue is settled. On the other hand there is general agreement among those scientists involved with waste management that radioactive waste disposal is a rather trivial technical problem. Having it as one of my principal research specialties..., I am firmly convinced that 
What Comes to Mind / 2

Despite the fact that we already know a great deal about public perceptions in this area, we have two important reasons to learn more, hence this study. First, most of our knowledge comes from rather general questions (e.g., "How great is the risk of a nuclearwaste repository compared with the risks of $\mathrm{X}, \mathrm{Y}$, and Z?"). With some notable exceptions (see, e.g., Erikson, 1990: Lifton, 1967; and Weart, 1988), there have been few attempts to penetrate the surface veneer of nuclear fear and provide insight into the nature and pervasiveness of people's concerns, the origins of these concerns, the emotions that underlie them, and their likely stability.

Second, research has documented scientifically what manufacturers, entertainers, politicians, and their advertisers and public-relations specialists have presumed for a long time--images and perceptions exert powerful effects upon human behavior. Recent surveys of residents in one geographic locale, Phoenix, Arizona, have demonstrated remarkably negative imagery associated with the concept of an "underground nuclear waste storage facility" (Mountain West, 1989; Slovic et al., 1989). The nuclear weapons test site located near Yucca Mountain was found to have caused a modest amount of nuclear imagery to be associated with the state of Nevada in the minds of Phoenix residents. People who associated nuclear imagery with Nevada also tended to express much lower preference for Nevada as a place to vacation. These and other findings have led a review panel to conclude:

"The greatest potential socioeconomic difficulty of the proposed repository [at Yucca Mountain] stems from the intense negative imagery associated by the

this radioactive waste from nuclear power operations represents less of a health hazard than the waste from any other large technological industry."

B. L. Cohen (1983, p. 119) 
What Comes to Mind / 3

vulnerability of the Nevada economy to changes in its public image. Because of the high profile nature of the whole nuclear waste disposal program, the potential exists for Nevada to become associated with this negative imagery to the detriment of its attempts to attract tourists, conventions, migrants, and new industry to the state."

(Technical Review Committee, 1990, p. 4)

In light of the potential for repository images to infiltrate the images of Las Vegas, other Nevada cities, and the State of Nevada itself, the present study was conducted to determine the precise nature of these images among people throughout the United States, including Nevada.

\subsection{Method}

\subsection{The Method of Continued Associations}

Our approach employs word associations to evoke the imagery, knowledge, attitudes, beliefs, and affective states associated with the concept of a nuclear-waste repository. The potential for word associations to reveal the mental content of a person's subjective experience was recognized by Plato and has a long history in psychology, going back to Galton (1880), Wundt (1883), and Freud (1924). More recently, Szalay and Deese (1978) have employed the method of continued associations to assess people's subjective representative systems for a wide range of concepts. This method requires the subject to make repeated associations to the same stimulus, for example,

$$
\begin{aligned}
& \text { war: soldier } \\
& \text { war: fight } \\
& \text { war: killing } \\
& \text { war: fear } \\
& \text { war: enemy } \\
& \text { war: etc. }
\end{aligned}
$$


What Comes to Mind / 4

Szalay and Deese argue that this association technique is an easy and efficient way to determine the contents and representational systems of human minds without requiring those contents to be expressed in the full discursive structure of language. In fact, we may reveal ourselves through associations in ways we might find difficult to do if we were required to spell out the full propositions behind these associations through answers to questions. Szalay and Deese further contend that responses produced by the method of continued associations are not erratic and whimsical, but are stable and relate clearly and naturally to a person's experiences. They are organized and structured in much the same way as perceptions, beliefs, and attitudes.

A related view is provided by Fiske, Pratto, and Pavelchak (1983), who describe an image as a "cognitive representation, a conception, or an idea, potentially containing both concrete and abstract impressions; ... a mental picture, but not necessarily visual" (p.42). Fiske et al. studied citizens' images of nuclear war, noting that such images could hardly be created except through experiences with the media, books, films, articles, and discussion.

Cognitive images are often accompanied by affect and such affect-laden images have been found to have important behavioral consequences. Prejudicial images give rise to discrimination (Hamilton, 1981). Images of politicians affect voting behavior (Campbell, Converse, Miller, \& Stoke, 1960). Images of nuclear war affect an individual's level of antinuclear political activity (Fiske, Pratto, \& Pavelchak, 1983).

In a series of recent studies, we have employed the method of continued associations to document the relationship between word-association images, risk, preferences, and 
economically important behaviors. Slovic et al. $(1989,1990)$ demonstrated that cities and states had diverse positive and negative images that were quite stable within an individual over a 16-18 month time period. They showed that the degree of positive and negative affective content across a person's set of images for each stimulus city or stimulus state could accurately predict a person's expressed preferences among these places for future vacation sites, places to retire, or places to locate new businesses. Image quality was also found to be related to past and future vacations in a place. Kunreuther and Easterling (1990) have observed similar relationships between people's images of a city and the likelihood that they would attend a convention in that city.

\subsection{Survey Designs and Details}

Word associations stimulated by mention of a nuclear-waste repository were elicited from more than 3300 persons in four telephone surveys conducted between April, 1988 and January, 1990. Details of these surveys are provided in Table 1. In addition to a National survey, data were collected from three other populations of special interest: residents of Nevada because of that state's selection as the site of the proposed national repository; Phoenix and Southern California because these are the two major areas from which tourists and economic development in Nevada emanate. The Nevada survey consisted of a sample representative of the entire state and additional samples from Nye County, in which the Nuclear Test Site and the proposed repository site are located, from Lincoln County, which borders Nye County and would contain a major transportation corridor through which the 
Table 1

Image Surveys

\begin{tabular}{l|c|c|c}
\hline \hline Survey and Location & Dates & $\begin{array}{c}\text { Sample } \\
\text { Size }\end{array}$ & $\begin{array}{c}\text { Response } \\
\text { Rate (\%) }\end{array}$ \\
\hline Phoenix & $4 / 13-6 / 8 / 88$ & 802 & 72 \\
National & $10 / 21-12 / 7 / 89$ & 825 & 77 \\
Southern California & $12 / 6 / 89-1 / 1 / 90$ & 801 & 77 \\
& & & \\
NEVADA & & & \\
Statewide & $9 / 25-10 / 15 / 89$ & 500 & 74 \\
Nye County & $9 / 25-10 / 15 / 89$ & 204 & 74 \\
Lincoln County & $9 / 25-10 / 15 / 89$ & 101 & 84 \\
Esmeralda County & $9 / 25-10 / 15 / 89$ & 101 & 77 \\
& & & \\
Nevada Total & $9 / 25-10 / 15 / 89$ & 906 & 77 \\
& & & \\
\hline
\end{tabular}

Note: The repository stimulus was "underground nuclear waste storage facility" for the Phoenix study and "underground nuclear waste repository" for the National, Southern California, and Nevada surveys.

wastes would travel on its final approach to Yucca Mountain, and from Esmeralda County, another transport corridor a bit farther from the site. Response rates were high (72\% $84 \%)$ in all of the surveys. 
The images were elicited using a version of the method of continued associations adapted for a telephone interview. The first task in the Phoenix, Southern California, and National surveys was always word association to either a set of four cities or four states. In the Cities survey, the elicitation interview proceeded as follows:

"My first question involves word association. For example, when I mention the word baseball, you might think of the World Series, Reggie Jackson, summertime, or even hot dogs. Today, I am interested in the first SIX thoughts or images that come to mind when you hear the name of a PLACE.

Think about for a minute. When you think about [CITY] for a minute. When you think about [CITY] , what is the first thought or image that comes to mind?

What is the next thought or image you have when I say

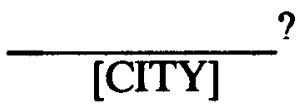

\section{[CITY]} Your next thought or image?

What is another thought or image you have about

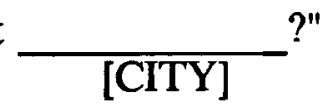

This continued until six associations were produced or the respondent drew a blank. Then the procedure was repeated for the next city.

Following the elicitation of images, respondents were asked to rate each image they had produced on a scale ranging from very positive (which was later coded by us as +2 ), somewhat positive $(+1)$, neutral $(0)$, somewhat negative $(-1)$, or very negative $(-2)$.

Respondents were then asked to rank the four cities/states according to their attractiveness as vacation sites. Additional questions assessed the extent of previous visits or living experiences in each of the cities or states. Next, up to six images were elicited to 
What Comes to Mind / 8 the stimulus "underground nuclear waste storage facility" (Phoenix survey) and "underground nuclear waste repository" (Southern California and National surveys). Following the elicitation of repository associations, respondents rated each association they gave on the same very positive to very negative scale used with the city or state associations.

Phoenix survey also asked respondents to produce images to the stimulus phrase "nuclear test site." The Southern California and National survey included a variety of other questions comparing perceptions of radioactive waste with other hazards and eliciting judgments about the impacts that a nearby repository might have on local communities. Each of these surveys concluded with a set of questions about the persons's education, income, and other demographic characteristics.

The Nevada surveys were structured slightly differently. The interview opened with a series of general questions about community satisfaction and perceptions of the seriousness of various environmental problems, including radioactive wastes. respondents were introduced to the word-association task and asked to produce associations to the word "Reno." They were then asked to associate to the words "underground nuclear waste repository" and, when they were finished, to rate the affective quality of each association on the positive to negative scale. The remainder of the survey contained specific questions about nuclear-waste repositories and questions to elicit background information about the respondent, much as in the other surveys. The present report describes only the analysis of the repository images. Analyses of the other material in these surveys is presented in Flynn, Slovic, Mertz, \& Toma (1990) and in Slovic, Layman, \& Flynn (1990). 
What Comes to Mind / 9

\subsection{Results}

\subsection{Analysis of the Combined Samples}

The 3,334 respondents in the National, Phoenix, California, and Nevada surveys produced a combined total of exactly 10,000 word-association images to the repository stimulus. We examined the content of these associations and developed a classification scheme to assign them to categories. This judgmental analysis resulted in 13 general or superordinate categories, one of which was a miscellaneous category. All but one superordinate category contained subordinate categories--in one case there were 17 subordinate categories that were judged to fit the theme of the major category. All in all, there were 92 distinct categories. Many of these contained multiple associations, judged to have similar meanings. For example, the subcategory labeled Dangerous/Toxic, within the superordinate category labeled Negative Consequences, included the terms danger, dangerous, unsafe, disaster, hazardous, poison, etc.

The 13 superordinate categories and their 92 subcategories contained 9439 wordassociation images ( $94.4 \%$ of the total). Some 561 associations were left uncategorized (5.6\% of the total).

Table 2 presents the 13 superordinate categories in order of their combined frequencies across all four samples. The one exception to this ordering is the relatively large miscellaneous category, which is presented last. The subordinate categories are also shown, ordered by frequency within their superordinate category.

Table 3 presents the same categorization as Table 1 but also includes the totals from the four separate surveys. 
What Comes to Mind / 10

Table 2

\section{NUCLEAR WASTE REPOSITORY IMAGE HIERARCHY ACROSS FOUR SAMPLES}

There are 10,000 images across the National, Phoenix, California and Nevada Samples, 9439 of which have been categorized; 561 images have not been categorized.

A superordinate structure has been created. Both the superordinate categories and the subordinate categories within them are arranged according to decreasing number of images.

The hierarchy ends with a miscellaneous set of subordinate categories that do not fit into the superordinate structure.

\begin{tabular}{|c|c|c|c|c|}
\hline $\begin{array}{l}\text { CAT } \\
\text { NO. }\end{array}$ & FRQ & $\begin{array}{l}\text { PER- } \\
\text { CENT }\end{array}$ & SUBORDINATE CATEGORY & SUPERORDINATE CATEGORY \\
\hline a & 1683 & 16.83 & Dangerous / Toxic & I. NEGATIVE CONSEQUENCES \\
\hline b & 783 & 7.83 & Death / Sickness & I. NEGATIVE CONSEQUENCES \\
\hline c & 692 & 6.92 & Environmental Damage & I. NEGATIVE CONSEQUENCES \\
\hline d & 216 & 2.16 & Leakage & I. NEGATIVE CONSEQUENCES \\
\hline e & 133 & 1.33 & Destruction & I. NEGATIVE CONSEQUENCES \\
\hline f & 18 & 0.18 & Pain and Suffering & I. NEGATIVE CONSEQUENCES \\
\hline g & 7 & 0.07 & Uninhabitable & I. NEGATIVE CONSEQUENCES \\
\hline h & 6 & 0.06 & Local Repository Area Consequences & I. NEGATIVE CONSEQUENCES \\
\hline$:$ & 8 & 0.08 & Negative - Other & I. NEGATIVE CONSEQUENCES \\
\hline TOTAL & 3546 & 35.46 & & \\
\hline a & 681 & 6.81 & Bad / Negative & II. NEGATIVE CONCEPTS \\
\hline b & 401 & 4.01 & Scary & II. NEGATIVE CONCEPTS \\
\hline c & 296 & 2.96 & Unnecessary / Opposed & II. NEGATIVE CONCEPTS \\
\hline d & 273 & 2.73 & Not Near Me & II. NEGATIVE CONCEPTS \\
\hline e & 126 & 1.26 & War / Annihilation & II. NEGATIVE CONCEPTS \\
\hline f & 41 & 0.41 & Societally Unpopular & II. NEGATIVE CONCEPTS \\
\hline g & 40 & 0.40 & Crime and Corruption & II. NEGATIVE CONCEPTS \\
\hline h & 39 & 0.39 & Decay / Slime / Smell & II. NEGATIVE CONCEPTS \\
\hline $\mathbf{i}$ & 37 & 0.37 & Darkness / Emptyness & II. NEGATIVE CONCEPTS \\
\hline j & 32 & 0.32 & Negative Toward Decision Makers and Process & II. NEGATIVE CONCEPTS \\
\hline $\mathbf{k}$ & 24 & 0.24 & Commands to Not Build or to Eliminate Them & II. NEGATIVE CONCEPTS \\
\hline 1 & 19 & 0.19 & Wrong or Bad Solution & II. NEGATIVE CONCEPTS \\
\hline $\mathbf{m}$ & 15 & 0.15 & No Nuclear, Stop Producing & II. NEGATIVE CONCEPTS \\
\hline $\mathbf{n}$ & 14 & 0.14 & Unjust & II. NEGATIVE CONCEPTS \\
\hline o & 10 & 0.10 & Violence & II. NEGATIVE CONCEPTS \\
\hline p & 5 & 0.05 & Prohibited & II. NEGATIVE CONCEPTS \\
\hline$q$ & 15 & 0.15 & Negative - Other & II. NEGATIVE CONCEPTS \\
\hline TOTAL & 2068 & 20.68 & & \\
\hline $\mathbf{a}$ & 245 & 2.45 & Non-Nevada Locations & III. LOCATIONS \\
\hline b & 243 & 2.43 & Storage Location / Containers & III. LOCATIONS \\
\hline c & 237 & 2.37 & Desert / Barren & III. LOCATIONS \\
\hline
\end{tabular}


What Comes to Mind / 11

Table 2, continued

\begin{tabular}{|c|c|c|c|c|}
\hline $\begin{array}{l}\text { CAT } \\
\text { NO. }\end{array}$ & FRQ & $\begin{array}{l}\text { PER- } \\
\text { CENT }\end{array}$ & SUBORDINATE CATEGORY & SUPERORDINATE CATEGORY \\
\hline d & 227 & 2.27 & Nevada / Las Vegas & III. LOCATIONS \\
\hline e & 215 & 2.15 & Waste / Garbage / Dumps & III. LOCATIONS \\
\hline f & 107 & 1.07 & Isolated & III. LOCATIONS \\
\hline g & 66 & 0.66 & Facilities and Their Construction & III. LOCATIONS \\
\hline h & 30 & 0.30 & Bury It & III. LOCATIONS \\
\hline $\mathbf{i}$ & 20 & 0.20 & Locations - Other & III. LOCATIONS \\
\hline TOTAL & 1390 & 13.90 & & \\
\hline a & 336 & 3.36 & Radiation / Nuclear & IV. RADIATION, PHYSICAL STATES \\
\hline $\mathbf{b}$ & 55 & 0.55 & Chemicals \& Physical States (Liquids, Gases) & IV. RADIATION, PHYSICAL STATES \\
\hline c & 33 & 0.33 & Fire / Hot & IV. RADIATION, PHYSICAL STATES \\
\hline TOTAL & 424 & 4.24 & & \\
\hline $\mathbf{a}$ & 228 & 2.28 & Safe and Secure & V. SAFETY, SECURITY \\
\hline $\mathbf{b}$ & 44 & 0.44 & Facilities Security & V. SAFETY, SECURITY \\
\hline c & 32 & 0.32 & Control, Containment and Cleanup & V. SAFETY, SECURITY \\
\hline d & 27 & 0.27 & Caution & V. SAFETY, SECURITY \\
\hline TOTAL & 331 & 3.31 & & \\
\hline a & 119 & 1.19 & Problems & VI. CONCERNS \\
\hline \multirow[t]{2}{*}{ b } & 58 & 0.58 & Questions & VI. CONCERNS \\
\hline & 25 & 0.25 & Health & VI. CONCERNS \\
\hline d & 19 & 0.19 & Unsolvable & VI. CONCERNS \\
\hline e & 18 & 0.18 & Family & VI. CONCERNS \\
\hline f & 14 & 0.14 & Uncontrolled & VI. CONCERNS \\
\hline g & 13 & 0.13 & Controversy & VI. CONCERNS \\
\hline h & 11 & 0.11 & Unpredictable & VI. CONCERNS \\
\hline \multirow[t]{2}{*}{$\mathbf{i}$} & 8 & 0.08 & Mistakes & VI. CONCERNS \\
\hline & 7 & 0.07 & Serious & VI. CONCERNS \\
\hline k & 5 & 0.05 & Skeptical & VI. CONCERNS \\
\hline 1 & 14 & 0.14 & Concerns - Other & VI. CONCERNS \\
\hline TOTAL & 311 & 3.11 & & \\
\hline a & 125 & 1.25 & Government / Industry & VII. SOCIETAL INSTITUTIONS \\
\hline \multirow[t]{2}{*}{ b } & 106 & 1.06 & Military / Weapons & VII. SOCIETAL INSTITUTIONS \\
\hline & 42 & 0.42 & Science, Technology, Research and Progress & VII. SOCIETAL INSTITUTIONS \\
\hline d & 31 & 0.31 & Political Process & VII. SOCIETAL INSTITUTIONS \\
\hline TOTAL & 304 & 3.04 & & \\
\hline $\mathbf{a}$ & 124 & 1.24 & Natural Environment & VIII. ECOLOGY \\
\hline b & 25 & 0.25 & Food and Water Supply & VIII. ECOLOGY \\
\hline c & 9 & 0.09 & Climate & VIII. ECOLOGY \\
\hline TOTAL & 158 & 1.58 & & \\
\hline a & 156 & 1.56 & Necessary & IX. NECESSARY \\
\hline TOTAL & 156 & 1.56 & & \\
\hline
\end{tabular}

(Table continues) 
What Comes to Mind / 12

Table 2, continued

\begin{tabular}{|c|c|c|c|c|}
\hline $\begin{array}{l}\text { CAT } \\
\text { NO. }\end{array}$ & FRQ & $\begin{array}{l}\text { PER- } \\
\text { CENT }\end{array}$ & SUBORDINATE CATEGORY & SUPERORDINATE CATEGORY \\
\hline $\mathbf{a}$ & 58 & 0.58 & Cost & X. ECONOMICS \\
\hline \multirow[t]{2}{*}{ b } & 57 & 0.57 & Employment & X. ECONOMICS \\
\hline & 29 & 0.29 & Money / Income & X. ECONOMICS \\
\hline d & 5 & 0.05 & Economics - Other & X. ECONOMICS \\
\hline TOTAL & 149 & 1.49 & & \\
\hline $\mathbf{a}$ & 57 & 0.57 & Uninformed & XI. INFORMATION, KNOWLEDGE \\
\hline \multirow[t]{2}{*}{ b } & 39 & 0.39 & Unsure / Unknown & XI. INFORMATION, KNOWLEDGE \\
\hline & 24 & 0.24 & Curiosity, and Knowledge & XI. INFORMATION, KNOWLEDGE \\
\hline d & 9 & 0.09 & Media & XI. INFORMATION, KNOWLEDGE \\
\hline e & 2 & 0.02 & Information, Knowledge - Other & XI. INFORMATION, KNOWLEDGE \\
\hline TOTAL & 131 & 1.31 & & \\
\hline $\mathbf{a}$ & 59 & 0.59 & Positive, Unconcerned & XII. POSITIVE \\
\hline \multirow[t]{2}{*}{ b } & 25 & 0.25 & Effective & XII. POSITIVE \\
\hline & 9 & 0.09 & Improved Environment & XII. POSITIVE \\
\hline d & 3 & 0.03 & Feasible & XII. POSITIVE \\
\hline e & 1 & 0.01 & Positive - Other & XII. POSITIVE \\
\hline TOTAL & 97 & 0.97 & & \\
\hline a & 85 & 0.85 & Future / Long Lasting & XIII. MISCELLANEOUS \\
\hline \multirow[t]{2}{*}{ b } & 65 & 0.65 & Energy / Power & XIII. MISCELLANEOUS \\
\hline & 38 & 0.38 & Transportation & XIII. MISCELLANEOUS \\
\hline d & 31 & 0.31 & Find Alternatives & XIII. MISCELLANEOUS \\
\hline \multirow[t]{2}{*}{ e } & 29 & 0.29 & Natural Disasters (Potential or Actual) & XIII. MISCELLANEOUS \\
\hline & 22 & 0.22 & Population & XIII. MISCELLANEOUS \\
\hline $\mathbf{g}$ & 21 & 0.21 & Degree of Distance & XIII. MISCELLANEOUS \\
\hline h & 20 & 0.20 & Neutral / Apathetic / Mixed Feelings & XIII. MISCELLANEOUS \\
\hline i & 14 & 0.14 & Supervision / Responsibility & XIII. MISCELLANEOUS \\
\hline $\mathbf{j}$ & 12 & 0.12 & Public Figures & XIII. MISCELLANEOUS \\
\hline \multirow[t]{2}{*}{$\mathbf{k}$} & 11 & 0.11 & Fiction & XIII. MISCELLANEOUS \\
\hline & 9 & 0.09 & Problem Avoidance & XIII. MISCELLANEOUS \\
\hline $\mathbf{m}$ & 8 & 0.08 & Inevitability & XIII. MISCELLANEOUS \\
\hline$\overline{\mathbf{n}}$ & 5 & 0.05 & Faith & XIII. MISCELLANEOUS \\
\hline o & 4 & 0.04 & O.K. If... & XIII. MISCELLANEOUS \\
\hline TOTAL & 374 & 3.74 & & \\
\hline
\end{tabular}


What Comes to Mind / 13

Table 3

NUCLEAR WASTE IMAGE HIERARCHY -- TOTALS

FOR FOUR SURVEYS

\begin{tabular}{|c|c|c|c|c|c|c|c|c|c|c|}
\hline & \multicolumn{5}{|c|}{ NUMBER OF IMAGES } & \multicolumn{5}{|c|}{ PERCENT } \\
\hline & COMB & NEV & NAT & CAL & PHX & COMB & NEV & NAT & CAL & PHX \\
\hline \multicolumn{11}{|l|}{ I. NEGATIVE CONSEQUENCES } \\
\hline a Dangerous / Toxic & 1683 & 499 & 393 & 403 & 388 & 16.83 & 20.38 & 16.21 & 16.15 & 14.74 \\
\hline b Death / Sickness & 783 & 205 & 183 & 190 & 205 & 7.83 & 8.37 & 7.55 & 7.61 & 7.79 \\
\hline c Environmental Damage & 692 & 166 & 199 & 187 & 140 & 6.92 & 6.78 & 8.21 & 7.49 & 5.32 \\
\hline d Leakage & 216 & 90 & 44 & 41 & 41 & 2.16 & 3.68 & 1.82 & 1.64 & 1.56 \\
\hline e Destruction & 133 & 30 & 46 & 25 & 32 & 1.33 & 1.23 & 1.90 & 1.00 & 1.22 \\
\hline f Pain and Suffering & 18 & 4 & 6 & 4 & 4 & 0.18 & 0.16 & 0.25 & 0.16 & 0.15 \\
\hline g Uninhabitable & 7 & 1 & 2 & 3 & 1 & 0.07 & 0.04 & 0.08 & 0.12 & 0.04 \\
\hline h Local Repository Area Consequences & 6 & 0 & 4 & 2 & $\mathbf{0}$ & 0.06 & 0.00 & 0.17 & 0.08 & 0.00 \\
\hline i Negative Consequences - Other & 8 & 0 & 4 & 4 & 0 & 0.08 & 0.00 & 0.17 & 0.16 & 0.00 \\
\hline TOTAL & 3546 & 995 & 881 & 859 & 811 & 35.46 & 40.65 & 36.34 & 34.42 & 30.81 \\
\hline \multicolumn{11}{|l|}{ II. NEGATIVE CONCEPTS } \\
\hline a Bad / Negative & 681 & 126 & 159 & 200 & 196 & 6.81 & 5.15 & 6.56 & 8.01 & 7.45 \\
\hline b Scary & 401 & 93 & 107 & 100 & 102 & 4.01 & 3.80 & 4.41 & 4.01 & 3.88 \\
\hline c Unnecessary / Opposed & 296 & 74 & 66 & 68 & 88 & 2.96 & 3.02 & 2.72 & 2.72 & 3.34 \\
\hline d Not Near Me & 273 & 33 & 79 & 90 & 71 & 2.73 & 1.35 & 3.26 & 3.61 & 2.70 \\
\hline e War / Annihilation & 126 & 11 & 27 & 28 & 59 & 1.26 & 0.45 & 1.11 & 1.12 & 2.24 \\
\hline f Societally Unpopular & 41 & 8 & 17 & 6 & 10 & 0.41 & 0.33 & 0.70 & 0.24 & 0.38 \\
\hline g Crime and Corruption & 40 & 8 & 8 & 14 & 10 & 0.40 & 0.33 & 0.33 & 0.56 & 0.38 \\
\hline h Decay / Slime / Smell & 39 & 13 & 6 & 6 & 14 & 0.39 & 0.53 & 0.25 & 0.24 & 0.53 \\
\hline i Darkness / Emptyness & 37 & 4 & 9 & 12 & 12 & 0.37 & 0.16 & 0.37 & 0.48 & 0.46 \\
\hline j Negative Toward Decision Makers and Process & 32 & 8 & 10 & 10 & 4 & 0.32 & 0.33 & 0.41 & 0.40 & 0.15 \\
\hline k Commands to Not Build or to Eliminate Them & 24 & 5 & 8 & 7 & 4 & 0.24 & 0.20 & 0.33 & 0.28 & 0.15 \\
\hline 1 Wrong or Bad Solution & 19 & 6 & 5 & 3 & 5 & 0.19 & 0.25 & 0.21 & 0.12 & 0.19 \\
\hline m No Nuclear, Stop Producing & 15 & 1 & 6 & 6 & 2 & 0.15 & 0.04 & 0.25 & 0.24 & 0.08 \\
\hline n Unjust & 14 & 3 & 5 & 4 & 2 & 0.14 & 0.12 & 0.21 & 0.16 & 0.08 \\
\hline o Violence & 10 & 5 & 1 & 2 & 2 & 0.10 & 0.20 & 0.04 & 0.08 & 0.08 \\
\hline p Prohibited & 5 & 3 & 0 & 2 & $\mathbf{0}$ & 0.05 & 0.12 & 0.00 & 0.08 & 0.00 \\
\hline q Negative - Other & 15 & 1 & 5 & 5 & 4 & 0.15 & 0.04 & 0.21 & 0.20 & 0.15 \\
\hline TOTAL & 2068 & 402 & 518 & 563 & 585 & 20.68 & 16.42 & 21.37 & 22.56 & 22.23 \\
\hline \multicolumn{11}{|l|}{ III. LOCATIONS } \\
\hline a Non-Nevada Locations & 245 & 6 & 60 & 78 & 100 & 2.45 & 0.25 & 2.48 & 3.13 & 3.80 \\
\hline b Storage Location / Containers & 243 & 71 & 66 & 57 & 49 & 2.43 & 2.90 & 2.72 & 2.28 & 1.86 \\
\hline c Desert / Barren & 237 & 31 & 67 & 64 & 75 & 2.37 & 1.27 & 2.76 & 2.56 & 2.85 \\
\hline d Nevada / Las Vegas & 227 & 44 & 39 & 45 & 99 & 2.27 & 1.80 & 1.61 & 1.80 & 3.76 \\
\hline e Waste / Garbage / Dumps & 215 & 50 & 38 & 50 & 77 & 2.15 & 2.04 & 1.57 & 2.00 & 2.93 \\
\hline f Isolated & 107 & 13 & 32 & 32 & 30 & 1.07 & 0.53 & 1.32 & 1.28 & 1.14 \\
\hline g Facilities and Their Construction & 66 & 24 & 15 & 19 & 8 & 0.66 & 0.98 & 0.62 & 0.76 & 0.30 \\
\hline h Bury It & 30 & 13 & 6 & 11 & 0 & 0.30 & 0.53 & 0.25 & 0.44 & 0.00 \\
\hline i Locations - Other & 20 & 0 & 9 & 7 & 4 & 0.20 & 0.00 & 0.37 & 0.28 & 0.15 \\
\hline TOTAL & 1390 & 252 & 332 & 363 & 442 & 13.90 & 10.29 & 13.70 & 14.54 & 16.79 \\
\hline
\end{tabular}

(Table continues) 


\begin{tabular}{|c|c|c|c|c|c|c|c|c|c|c|}
\hline & \multicolumn{5}{|c|}{ NUMBER OF IMAGES } & \multicolumn{5}{|c|}{ PERCENT } \\
\hline & COMB & NEV & NAT & CAI & PHX & $\mathrm{OMB}$ & NEV & NAT & CAL & PHX \\
\hline \multicolumn{11}{|l|}{ IV. RADIATION, PHYSICAL STATES } \\
\hline a Radiation / Nuclear & 336 & 74 & 51 & 63 & 148 & 3.36 & 3.02 & 2.10 & 2.52 & 5.62 \\
\hline b Chemicals \& Physical States (Liquids, Gases) & 55 & 18 & 15 & 13 & 9 & 0.55 & 0.74 & 0.62 & 0.52 & 0.34 \\
\hline \multirow[t]{2}{*}{ c Fire / Hot } & 33 & 3 & 8 & 9 & 13 & 0.33 & 0.12 & 0.33 & 0.36 & 0.49 \\
\hline & 424 & 95 & 74 & 85 & 170 & 4.24 & 3.88 & 3.05 & 3.41 & 6.46 \\
\hline \multicolumn{11}{|l|}{ V. SAFETY, SECURTTY } \\
\hline a Safe and Secure & 228 & 102 & 48 & 47 & 31 & 2.28 & 4.17 & 1.98 & 1.88 & 1.18 \\
\hline b Facilities Security & 44 & 2 & 10 & 25 & 7 & 0.44 & 0.08 & 0.41 & 1.00 & 0.27 \\
\hline c Control, Containment and Cleanup & 32 & 11 & 10 & 8 & 3 & 0.32 & 0.45 & 0.41 & 0.32 & 0.11 \\
\hline d Caution & 27 & 13 & 7 & 2 & 5 & 0.27 & 0.53 & 0.29 & 0.08 & 0.19 \\
\hline TOTAL & 331 & 128 & 75 & 82 & 46 & 3.31 & 5.23 & 3.09 & 3.29 & 1.75 \\
\hline \multicolumn{11}{|l|}{ VI. CONCERNS } \\
\hline a Problems & 119 & 22 & 32 & 26 & 39 & 1.19 & 0.90 & 1.32 & 1.04 & 1.48 \\
\hline b Questions & 58 & 1 & 23 & 18 & 16 & 0.58 & 0.04 & 0.95 & 0.72 & 0.61 \\
\hline c Health & 25 & 14 & 5 & 4 & 2 & 0.25 & 0.57 & 0.21 & 0.16 & 0.08 \\
\hline d Unsolvable & 19 & 1 & 5 & 12 & 1 & 0.19 & 0.04 & 0.21 & 0.48 & 0.04 \\
\hline e Family & 18 & 6 & 3 & 5 & 4 & 0.18 & 0.25 & 0.12 & 0.20 & 0.15 \\
\hline f Uncontrolled & 14 & 5 & 2 & 3 & 4 & 0.14 & 0.20 & 0.08 & 0.12 & 0.15 \\
\hline$g$ Controversy & 13 & 5 & 3 & 4 & 1 & 0.13 & 0.20 & 0.12 & 0.16 & 0.04 \\
\hline h Unpredictable & 11 & 2 & 3 & 3 & 3 & 0.11 & 0.08 & 0.12 & 0.12 & 0.11 \\
\hline i Mistakes & 8 & 1 & 3 & 3 & 1 & 0.08 & 0.04 & 0.12 & 0.12 & 0.04 \\
\hline j Serious & 7 & 2 & $\mathbf{0}$ & 2 & 3 & 0.07 & 0.08 & 0.00 & 0.08 & 0.11 \\
\hline k Skeptical & 5 & 2 & 1 & 2 & $\mathbf{0}$ & 0.05 & 0.08 & 0.04 & 0.08 & 0.00 \\
\hline 1 Concerns - Other & 14 & 8 & 2 & 3 & 1 & 0.14 & 0.33 & 0.08 & 0.12 & 0.04 \\
\hline TOTAL & 311 & 69 & 82 & 85 & 75 & 3.11 & 2.82 & 3.38 & 3.41 & 2.85 \\
\hline \multicolumn{11}{|l|}{ VII. SOCIETAL INSTITUTIONS } \\
\hline a Government / Industry & 125 & 27 & 25 & 26 & 47 & 1.25 & 1.10 & 1.03 & 1.04 & 1.79 \\
\hline b Military / Weapons & 106 & 16 & 23 & 10 & 57 & 1.06 & 0.65 & 0.95 & 0.40 & 2.17 \\
\hline c Science, Technology, Research and Progress & 42 & 8 & 8 & 17 & 9 & 0.42 & 0.33 & 0.33 & 0.68 & 0.34 \\
\hline d Political Process & 31 & 12 & 8 & 3 & 8 & 0.31 & 0.49 & 0.33 & 0.12 & 0.30 \\
\hline TOTAL & 304 & 63 & 64 & 56 & 121 & 3.04 & 2.57 & 2.64 & 2.24 & 4.60 \\
\hline \multicolumn{11}{|l|}{ VIII. ECOLOGY } \\
\hline a Natural Environment & 124 & 46 & 28 & 22 & 28 & 1.24 & 1.88 & 1.16 & 0.88 & 1.06 \\
\hline b Food and Water Supply & 25 & 5 & 9 & 7 & 4 & 0.25 & 0.20 & 0.37 & 0.28 & 0.15 \\
\hline c Climate & 9 & 3 & 2 & 2 & 2 & 0.09 & 0.12 & 0.08 & 0.08 & 0.08 \\
\hline TOTAL & 158 & 54 & 39 & 31 & 34 & 1.58 & 2.21 & 1.61 & 1.24 & 1.29 \\
\hline \multicolumn{11}{|l|}{ IX. NECESSARY } \\
\hline a Necessary & 156 & 40 & 36 & 46 & 34 & 1.56 & 1.63 & 1.49 & 1.84 & 1.29 \\
\hline & 156 & 40 & 36 & 46 & 34 & 1.56 & 1.63 & 1.49 & 1.84 & 1.29 \\
\hline \multicolumn{11}{|l|}{ X. ECONOMICS } \\
\hline a Cost & 58 & 11 & 20 & 8 & 19 & 0.58 & 0.45 & 0.83 & 0.32 & 0.72 \\
\hline b Employment & 57 & 44 & 4 & 5 & 4 & 0.57 & 1.80 & 0.17 & 0.20 & 0.15 \\
\hline c Money / Income & 29 & 14 & 2 & 6 & 7 & 0.29 & 0.57 & 0.08 & 0.24 & 0.27 \\
\hline d Economics - Other & 5 & 5 & 0 & 0 & 0 & 0.05 & 0.20 & 0.00 & 0.00 & 0.00 \\
\hline TOTAL & 149 & 74 & 26 & 19 & 30 & 1.49 & 3.02 & 1.07 & 0.76 & 1.14 \\
\hline
\end{tabular}

(Table continues) 
Table 3, continued

COMB NEV NAT CAL PHX COMB NEV NAT CAL PHX

XI. INFORMATION, KNOWLEDGE
a Uninformed
b Unsure / Unknown
c Curiosity, Interest and Knowledge
d Media e Information, Knowledge - Other
TOTAL

\section{POSITIVE}

a Positive, Unconcerned

b Effective

c Improved Environment

d Feasible

e Positive - Other TOTAL
XIII. MISCELLANEOUS

a Future / Long Lasting

b Energy / Power

c Transportation

d Find Alternatives

e Natural Disasters (Potential or Actual)

f Population

g Degree of Distance

h Neutral / Apathetic / Mixed Feelings

i Supervision / Responsibility

j Public Figures

k Fiction

1 Problem Avoidance

m Inevitability

n Faith

o O.K. If...

$\begin{array}{rrrrrrrrrr}57 & 7 & 11 & 15 & 24 & 0.57 & 0.29 & 0.45 & 0.60 & 0.91 \\ 39 & 15 & 5 & 7 & 12 & 0.39 & 0.61 & 0.21 & 0.28 & 0.46 \\ 24 & 8 & 2 & 7 & 7 & 0.24 & 0.33 & 0.08 & 0.28 & 0.27 \\ 9 & 1 & 1 & 3 & 4 & 0.09 & 0.04 & 0.04 & 0.12 & 0.15 \\ 2 & 2 & 0 & 0 & 0 & 0.02 & 0.08 & 0.00 & 0.00 & 0.00 \\ 131 & 33 & 19 & 32 & 47 & 1.31 & 1.35 & 0.78 & 1.28 & 1.79\end{array}$

$\begin{array}{rrrrrrrrrr}59 & 18 & 11 & 15 & 15 & 0.59 & 0.74 & 0.45 & 0.60 & 0.57 \\ 25 & 5 & 9 & 10 & 1 & 0.25 & 0.20 & 0.37 & 0.40 & 0.04 \\ 9 & 4 & 2 & 2 & 1 & 0.09 & 0.16 & 0.08 & 0.08 & 0.04 \\ 3 & 1 & 2 & 0 & 0 & 0.03 & 0.04 & 0.08 & 0.00 & 0.00 \\ 1 & 0 & 1 & 0 & 0 & 0.01 & 0.00 & 0.04 & 0.00 & 0.00 \\ 97 & 28 & 25 & 27 & 17 & 0.97 & 1.14 & 1.03 & 1.08 & 0.65\end{array}$

$\begin{array}{rrrrrrrrrr}85 & 17 & 24 & 32 & 11 & 0.85 & 0.69 & 0.99 & 1.28 & 0.42 \\ 65 & 2 & 11 & 16 & 36 & 0.65 & 0.08 & 0.45 & 0.64 & 1.37 \\ 38 & 29 & 4 & 2 & 3 & 0.38 & 1.18 & 0.17 & 0.08 & 0.11 \\ 31 & 3 & 11 & 11 & 6 & 0.31 & 0.12 & 0.45 & 0.44 & 0.23 \\ 29 & 16 & 6 & 6 & 1 & 0.29 & 0.65 & 0.25 & 0.24 & 0.04 \\ 22 & 6 & 7 & 7 & 2 & 0.22 & 0.25 & 0.29 & 0.28 & 0.08 \\ 21 & 17 & 2 & 2 & 1 & 0.21 & 0.69 & 0.08 & 0.08 & 0.04 \\ 20 & 1 & 3 & 5 & 11 & 0.20 & 0.04 & 0.12 & 0.20 & 0.42 \\ 14 & 5 & 7 & 1 & 1 & 0.14 & 0.20 & 0.29 & 0.04 & 0.04 \\ 12 & 0 & 3 & 3 & 6 & 0.12 & 0.00 & 0.12 & 0.12 & 0.23 \\ 11 & 0 & 2 & 6 & 3 & 0.11 & 0.00 & 0.08 & 0.24 & 0.11 \\ 9 & 0 & 2 & 3 & 4 & 0.09 & 0.00 & 0.08 & 0.12 & 0.15 \\ 8 & 3 & 3 & 1 & 1 & 0.08 & 0.12 & 0.12 & 0.04 & 0.04 \\ 5 & 1 & 3 & 0 & 1 & 0.05 & 0.04 & 0.12 & 0.00 & 0.04 \\ 4 & 0 & 1 & 3 & 0 & 0.04 & 0.00 & 0.04 & 0.12 & 0.00 \\ 374 & 100 & 89 & 98 & 87 & 3.74 & 4.08 & 3.67 & 3.93 & 3.31\end{array}$

$\begin{array}{lrrrrr}\text { TOTAL NUMBER OF ITEMS CATEGORIZED } & 9439 & 2333 & 2260 & 2346 & 2499 \\ \text { NUMBER OF UNCATEGORIZED ITEMS } & 561 & 115 & 164 & 150 & 133 \\ \text { TOTAL NUMBER OF ITEMS } & 10000 & 2448 & 2424 & 2496 & 2632\end{array}$

PERCENT OF ITEMS CATEGORIZED 
What Comes to Mind / 16

Table 4 presents the combined and individual survey results for the 92 subordinate categories, unconstrained by their superordinate categories, ordered by overall frequency in the combined total. A complete listing of all 10,000 images, including those that were not categorized, is presented in the Appendix.

These various tables contain a great amount of information about the nature of people's images of a nuclear-waste repository. The most obvious and most important finding is the extreme negative quality of these images. The three most frequent single associations were dangerous $(n=539)$, danger $(n=378)$, and death $(n=306)$. The dominant subordinate category, Dangerous/Toxic, contained almost $17 \%$ of the total number of images. The five leading subordinate categories

Dangerous/Toxic $16.83 \%$
Death/Sickness
Environmental Damage
Bad/Negative
Scary

were thoroughly negative in affective quality and accounted for more than $42 \%$ of the total number of images. The two dominant superordinate categories, Negative Consequences and Negative Concepts accounted for more than $56 \%$ of the total number of images. Many of the smaller categories and subcategories were also quite negative in tone.

Positive imagery was indeed rare. Category XII, Positive, accounted for only $1 \%$ of the images. Other generally positive concepts, Necessary (Category IX), employment 
What Comes to Mind / 17

Table 4

\section{SUBORDINATE CATEGORIES ORDERED BY DECREASING FREQUENCY}

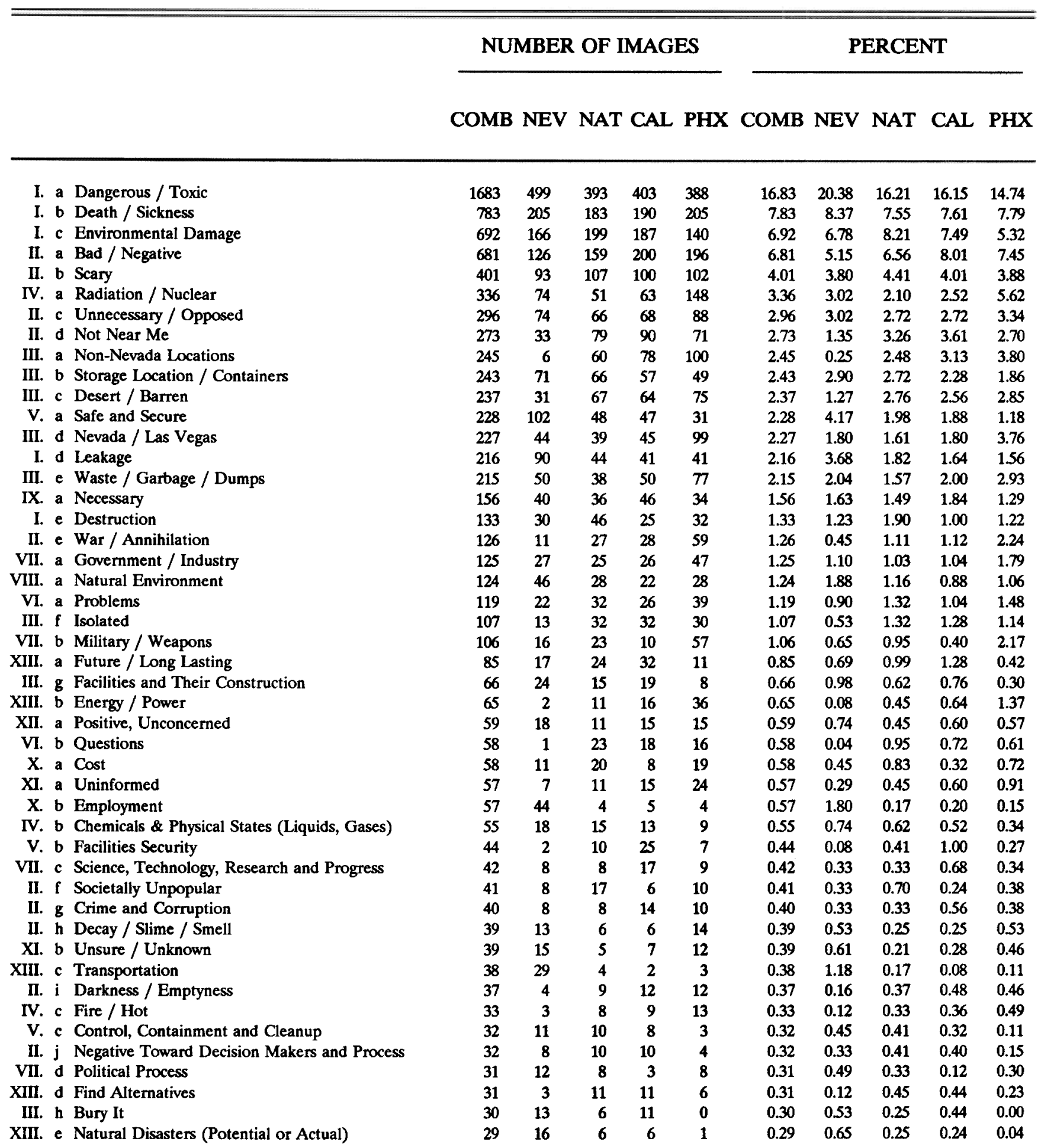

(Table continues) 
What Comes to Mind / 18

Table 4, continued

COMB NEV NAT CAL PHX COMB NEV NAT CAL PHX

\begin{tabular}{|c|c|c|c|c|c|c|c|c|c|c|c|}
\hline $\mathbf{X}$ & c Money / Income & 29 & 14 & 2 & 6 & 7 & 0.29 & 0.57 & 0.08 & 0.24 & 0.27 \\
\hline V. & d Caution & 27 & 13 & 7 & 2 & 5 & 0.27 & 0.53 & 0.29 & 0.08 & 0.19 \\
\hline VI. & c Health & 25 & 14 & 5 & 4 & 2 & 0.25 & 0.57 & 0.21 & 0.16 & 0.08 \\
\hline VIII. & b Food and Water Supply & 25 & 5 & 9 & 7 & 4 & 0.25 & 0.20 & 0.37 & 0.28 & 0.15 \\
\hline XII. & b Effective & 25 & 5 & 9 & 10 & 1 & 0.25 & 0.20 & 0.37 & 0.40 & 0.04 \\
\hline II. & k Commands to Not Build or to Eliminate Them & 24 & 5 & 8 & 7 & 4 & 0.24 & 0.20 & 0.33 & 0.28 & 0.15 \\
\hline XI. & c Curiosity, Interest and Knowledge & 24 & 8 & 2 & 7 & 7 & 0.24 & 0.33 & 0.08 & 0.28 & 0.27 \\
\hline XIII. & f Population & 22 & 6 & 7 & 7 & 2 & 0.22 & 0.25 & 0.29 & 0.28 & 0.08 \\
\hline XIII. & g Degree of Distance & 21 & 17 & 2 & 2 & 1 & 0.21 & 0.69 & 0.08 & 0.08 & 0.04 \\
\hline III. & i Locations - Other & 20 & $\mathbf{0}$ & 9 & 7 & 4 & 0.20 & 0.00 & 0.37 & 0.28 & 0.15 \\
\hline XIII. & h Neutral / Apathetic / Mixed Feelings & 20 & 1 & 3 & 5 & 11 & 0.20 & 0.04 & 0.12 & 0.20 & 0.42 \\
\hline VI. & d Unsolvable & 19 & 1 & 5 & 12 & 1 & 0.19 & 0.04 & 0.21 & 0.48 & 0.04 \\
\hline II. & 1 Wrong or Bad Solution & 19 & 6 & 5 & 3 & 5 & 0.19 & 0.25 & 0.21 & 0.12 & 0.19 \\
\hline VI. & e Family & 18 & 6 & 3 & 5 & 4 & 0.18 & 0.25 & 0.12 & 0.20 & 0.15 \\
\hline I. & f Pain and Suffering & 18 & 4 & 6 & 4 & 4 & 0.18 & 0.16 & 0.25 & 0.16 & 0.15 \\
\hline II. & q Negative - Other & 15 & 1 & 5 & 5 & 4 & 0.15 & 0.04 & 0.21 & 0.20 & 0.15 \\
\hline II. & m Nuclear, Stop Producing & 15 & 1 & 6 & 6 & 2 & 0.15 & 0.04 & 0.25 & 0.24 & 0.08 \\
\hline VI. & f Uncontrolled & 14 & 5 & 2 & 3 & 4 & 0.14 & 0.20 & 0.08 & 0.12 & 0.15 \\
\hline II. & n Unjust & 14 & 3 & 5 & 4 & 2 & 0.14 & 0.12 & 0.21 & 0.16 & 0.08 \\
\hline XIII. & i Supervision/ Responsibility & 14 & 5 & 7 & 1 & 1 & 0.14 & 0.20 & 0.29 & 0.04 & 0.04 \\
\hline VI. & 1 Concerns - Other & 14 & 8 & 2 & 3 & 1 & 0.14 & 0.33 & 0.08 & 0.12 & 0.04 \\
\hline VI. & g Controversy & 13 & 5 & 3 & 4 & 1 & 0.13 & 0.20 & 0.12 & 0.16 & 0.04 \\
\hline XIII. & j Public Figures & 12 & 0 & 3 & 3 & 6 & 0.12 & 0.00 & 0.12 & 0.12 & 0.23 \\
\hline XIII. & k Fiction & 11 & 0 & 2 & 6 & 3 & 0.11 & 0.00 & 0.08 & 0.24 & 0.11 \\
\hline VI. & h Unpredictable & 11 & 2 & 3 & 3 & 3 & 0.11 & 0.08 & 0.12 & 0.12 & 0.11 \\
\hline II. & o Violence & 10 & 5 & 1 & 2 & 2 & 0.10 & 0.20 & 0.04 & 0.08 & 0.08 \\
\hline XII. & c Improved Environment & 9 & 4 & 2 & 2 & 1 & 0.09 & 0.16 & 0.08 & 0.08 & 0.04 \\
\hline XI. & d Media & 9 & 1 & 1 & 3 & 4 & 0.09 & 0.04 & 0.04 & 0.12 & 0.15 \\
\hline VIII. & c Climate & 9 & 3 & 2 & 2 & 2 & 0.09 & 0.12 & 0.08 & 0.08 & 0.08 \\
\hline XIII. & 1 Problem Avoidance & 9 & 0 & 2 & 3 & 4 & 0.09 & 0.00 & 0.08 & 0.12 & 0.15 \\
\hline I. & i Negative Consequences - Other & 8 & 0 & 4 & 4 & 0 & 0.08 & 0.00 & 0.17 & 0.16 & 0.00 \\
\hline XIII. & m Inevitability & 8 & 3 & 3 & 1 & 1 & 0.08 & 0.12 & 0.12 & 0.04 & 0.04 \\
\hline VI. & i Mistakes & 8 & 1 & 3 & 3 & 1 & 0.08 & 0.04 & 0.12 & 0.12 & 0.04 \\
\hline VI. & j Serious & 7 & 2 & 0 & 2 & 3 & 0.07 & 0.08 & 0.00 & 0.08 & 0.11 \\
\hline I. & g Uninhabitable & 7 & 1 & 2 & 3 & 1 & 0.07 & 0.04 & 0.08 & 0.12 & 0.04 \\
\hline I. & h Local Repository Area Consequences & 6 & 0 & 4 & 2 & $\mathbf{0}$ & 0.06 & 0.00 & 0.17 & 0.08 & 0.00 \\
\hline $\mathbf{X}$. & d Economics - Other & 5 & 5 & 0 & 0 & $\mathbf{0}$ & 0.05 & 0.20 & 0.00 & 0.00 & 0.00 \\
\hline II. & p Prohibited & 5 & 3 & $\mathbf{0}$ & 2 & 0 & 0.05 & 0.12 & 0.00 & 0.08 & 0.00 \\
\hline XIII. & n Faith & 5 & 1 & 3 & 0 & 1 & 0.05 & 0.04 & 0.12 & 0.00 & 0.04 \\
\hline VI. & k Skeptical & 5 & 2 & 1 & 2 & $\mathbf{0}$ & 0.05 & 0.08 & 0.04 & 0.08 & 0.00 \\
\hline XIII. & o o.K. If... & 4 & 0 & 1 & 3 & $\mathbf{0}$ & 0.04 & 0.00 & 0.04 & 0.12 & 0.00 \\
\hline XII. & d Feasible & 3 & 1 & 2 & 0 & 0 & 0.03 & 0.04 & 0.08 & 0.00 & 0.00 \\
\hline XI. & e Information, Knowledge - Other & 2 & 2 & 0 & $\mathbf{0}$ & $\mathbf{0}$ & 0.02 & 0.08 & 0.00 & 0.00 & 0.00 \\
\hline XII. & e Positive - Other & 1 & 0 & 1 & $\mathbf{0}$ & 0 & 0.01 & 0.00 & 0.04 & 0.00 & 0.00 \\
\hline
\end{tabular}


What Comes to Mind / 19

(Category $\mathrm{Xb}$ ), and money/income (Category $\mathrm{Xc}$ ) combined to total only $2.5 \%$ of the images.

Other noteworthy features of the combined data are:

- There were 227 associations to Nevada or places in Nevada (Category IIIc). Of these 155 were Nevada, 21 were Las Vegas, 29 were Yucca Mountain, and the rest were other cities or place names. There were also 36 mentions of New Mexico, the state in which the WIPP storage facility is located.

There were 232 associations pertaining to war, annihilation, weapons, and things military (Categories IIe and VIIb).

There were surprisingly few (85) associations relating to the long duration of storage necessary for nuclear wastes or the transfer of risk and responsibilities to future generations (XIIIa).

There were surprisingly few (38) transportation images (XIIIc).

The famous NIMBY position (not in my backyard) was expressed in 273 images (Category IId).

- Nuclear-waste repositories are sometimes referred to derisively as "dumps." Although dump imagery was definitely present, it was infrequent (40 associations).

Studies of risk perception have found that people perceive the risks of nuclear reactors and nuclear wastes as highly unknown, uncontrollable, inequitable, and of a dread quality. There were definite signs of these qualities in the images. For example, although the word "dread" was never mentioned specifically, many of the responses categorized as scary (IIb) reflect this quality (e.g., fear, horror, 
What Comes to Mind / 20

apprehension, terror). There were 39 associations in the category labeled unsure/unknown, and only 14 labeled uncontrolled. Inequity or unfairness was mentioned only a few times.

Lack of trust in DOE or other governmental agents is a common finding in studies of public perceptions of nuclear-waste management. Given the obvious importance of distrust, it appears surprisingly infrequently in the image set (mostly in Category IIj, Negative Toward Decision Makers and Process, and Categories IIl and Vli, dealing with mistakes). A number of images in the Bad/Negative category also seem to reflect lack of trust.

Jones et al. (1984) have attempted to characterize the key dimensions of stigma. Two of their major defining characteristics of stigma are peril and negative aesthetic qualities (ugliness, repulsion). These qualities dominate the repository images. Peril is pervasive throughout Categories I and II and elsewhere and negative aesthetics form the bulk of the subordinate categories bad/negative (IIa) and Decay, Slime, Smell (IIh).

\subsection{Analyses of Individual Surveys}

Is the picture derived from all 10,000 images similar for each of the separate survey samples? Close examination of Tables 2 and 3 shows that a) there are differences in some image frequencies from one sample to another but $b$ ) these differences are quite small and do not change the interpretations in any important ways.

The basic similarity across samples is evident from the totals for the two most dominant and most negative categories, I and II. Although the Nevada respondents had the 
What Comes to Mind / 21

highest percentage of images in Category I, they were lowest on Category II. Combining totals for the two categories gives a very uniform picture, ranging from a high of $61.9 \%$ in the National survey to a low of $55.9 \%$ in the Phoenix survey.

To the extent that there were sample differences, Nevada seemed to stand apart from the other three samples. Nevadans expressed relatively more imagery with regard to leakage (Category Id), safety and security (Va), economics (Category $\mathrm{X}$ as a whole and employment and money/income images in particular), transportation (XIIIc), and degree of distance (XIIIg). Nevadans had relatively less imagery regarding bad/negative things (IIa), not near me (IId), war and annihilation (IIe), non-Nevada locations (IIIa), desert, and barrenness (IIIc), isolation (IIIf), questions (VIb), and energy and power (XIIIb).

Phoenix residents also had a number of small imagery idiosyncrasies. They had relatively more images about Nevada and Las Vegas (IIId), waste, garbage, and dumps (IIIe), radiation and nuclear (IVa), Government and industry (VIIa), military and weapons (VIIb), and energy and power (XIIIg). They were lower with regard to dangerous and toxic (Ia), environmental damage (Ic), and safety and security (Va).

The National sample stood out only with regard to having more imagery about destruction (Ie) and less about waste, garbage, and dumps. The California sample stood out with regard to having more imagery about facilities' security $(\mathrm{Vb})$.

Part of the small deviance exhibited by the Nevada sample may be attributable to the fact that we have included data for the Nye, Lincoln, and Esmeralda County samples in the statewide total. These counties often differed from the statewide sample, hence their inclusion biases the statewide total somewhat. This can be seen from Table 4, which lists 
What Comes to Mind / 22

specific images that are disproportionately higher in the state sample (above the line) and disproportionately higher in the counties (below the line). The state sample tends to be higher on the negative images for Categories I and II. The counties have relatively more imagery dealing with transportation, location (i.e., the word "location"), management, ugliness, economy, and necessity.

Note that the counties are not always similar either. Lincoln County residents expressed considerably more imagery related to transportation than did residents of Esmeralda County. Nye County had relatively more imagery regarding management, economy, and necessity and less imagery regarding death.

\section{$\underline{3.3 \text { Demographic Variables }}$}

We have not yet completed a full analysis of the relationship between demographic variables and imagery. However, we have examined the relationships between demographic variables and a person's self-rating of the positive or negative affective value of his or her repository images. Table 6 presents these data for the first image given by the respondent in the California and National surveys. ${ }^{2}$ Examination of these data shows that demographic effects were present but were rarely large. The negativity of repository images is remarkably consistent across people of different ages, incomes, education levels, and political persuasions. There was a slight tendency for more women than men to rate their images as negative and for more men to rate their images as positive. People aged 65 years or

2 Each of these surveys had two subsamples depending on whether respondents provided images for cities or states. Each subsample had 400 or more respondents. Data in Table 6 are partitioned by subsamples. 
What Comes to Mind / 23

older were a bit more likely to rate their images as positive, as were people who reported their political orientation as very conservative.

\subsection{Discussion}

\subsection{What Have We Learned?}

What have we learned by asking more than 3500 people to perform the rather odd task of free-associating to the concept of a nuclear waste repository? Some would answer: the obvious--that people don't like nuclear waste. "What did you expect?"

We believe these images demonstrate an aversion so remarkably strong that to call it "negative" or a "dislike" hardly does it justice. What these images reveal are pervasive qualities of dread, revulsion, and anger; the raw materials of stigmatization and political opposition.

To us, these findings were not so obvious, prior to the studies. Nuclear waste is a by-product of an impressive technology capable of producing massive amounts of energy. Should there not be some representation of energy and its benefits--electricity, light, heat, employment, health, progress, the good life--scattered among the images? We observed almost none.

Second, we did not ask people to reflect on nuclear waste. We asked them about a storage facility (Phoenix survey) and a repository (other surveys). One might expect, following the predominant view of experts in this field, to find a substantial number of repository images reflecting the qualities "necessary" and "safe" (see footnote 1). We observed almost none. 
Table 5

Repository Images in Four Nevada Samples

\begin{tabular}{|c|c|c|c|c|c|}
\hline Word/Image & Total Number & Statewide & Nye County & Lincoln County & $\begin{array}{c}\text { Esmeralda } \\
\text { County }\end{array}$ \\
\hline Base Rate & 2476 & 60.0 & 19.7 & 10. & 10.2 \\
\hline Cancer & 34 & 82.4 & 11.8 & 2.9 & 2.9 \\
\hline Tragedy & 17 & 82.4 & 5.9 & 11.8 & 0.0 \\
\hline Future Generations & 30 & 76.7 & 10.0 & 3.3 & 10.0 \\
\hline Health & 64 & 75.0 & 10.9 & 6.3 & 7.8 \\
\hline Chemicals & 43 & 74.4 & 18.6 & 0.0 & 7.0 \\
\hline Death & 118 & 72.9 & 7.6 & 6.8 & 12.7 \\
\hline Contamination & 58 & 70.7 & 15.5 & 3.4 & 10.3 \\
\hline Negative & 80 & 70.0 & 13.8 & 8.8 & 7.5 \\
\hline Water & 49 & 67.3 & 14.3 & 10.2 & 8.2 \\
\hline Radioactivity & 70 & 65.7 & 22.9 & 10.0 & 1.4 \\
\hline Danger & 321 & 65.4 & 15.6 & 9.7 & 9.3 \\
\hline Contaminant & 106 & 65.1 & 22.6 & 5.7 & 6.6 \\
\hline Pollution & 96 & 64.6 & 17.7 & 8.3 & 9.4 \\
\hline Controversial & 67 & 53.7 & 19.4 & 16.4 & 10.4 \\
\hline Transportation & 29 & 51.7 & 17.2 & 24.1 & 6.9 \\
\hline Safety & 149 & 49.0 & 26.8 & 10.1 & 14.1 \\
\hline Location & 55 & 47.3 & 16.4 & 18.2 & 18.2 \\
\hline Management & 32 & 43.8 & 37.5 & 9.4 & 9.4 \\
\hline Ugly & 54 & 38.9 & 25.9 & 18.5 & 16.7 \\
\hline Economy & 77 & 36.4 & 35.1 & 11.7 & 16.9 \\
\hline Necessary & 70 & 28.6 & 34.3 & 18.6 & 18.6 \\
\hline
\end{tabular}

Note: Cell entries are percentages, which sum to 100 in each row. Entries above the line reflect specific images for which the state proportion is higher than its overall baseline $(60 \%)$. Entries below the line reflect images for which the state proportion is lower than its baseline (and the county proportions are generally higher than their overall baseline). 
Table 6

Repository Evaluations in Four Surveys: Demographic Effects

\begin{tabular}{|c|c|c|c|c|c|c|c|c|c|c|c|c|c|c|c|}
\hline \multicolumn{8}{|c|}{ California - Cities Survey } & \multicolumn{8}{|c|}{ California - States Survey } \\
\hline \multicolumn{8}{|c|}{$\begin{array}{l}\text { FEELINGS ABOUT THE FRST THOUGHT OR IMAGE THAT COMES TO MIND } \\
\text { ABOUT AN UNDERGROUND NUCLEAR WASTE REPOSTTORY } \\
\end{array}$} & \multicolumn{8}{|c|}{$\begin{array}{l}\text { FEEUNGS ABOUT THE FRST THOUGHT OR IMAGE THAT COMES TO MIND } \\
\text { ABOUT AN UNDERGROUND NUCLEAR WASTE REPOSTIORY } \\
\end{array}$} \\
\hline $\begin{array}{l}\text { Tabult- } \\
\text { ted(N) }\end{array}$ & $\begin{array}{l}\operatorname{CoL}-122 \\
\text { Kgy Groupe }\end{array}$ & $\begin{array}{l}\text { VERY } \\
\text { POSTIV } \\
\end{array}$ & $\begin{array}{l}\text { SMWHT } \\
\text { POSTIV }\end{array}$ & NEUL- & $\begin{array}{l}\text { SMWHT } \\
\text { NEGTIV }\end{array}$ & $\begin{array}{l}\text { VERY } \\
\text { NEGTIV } \\
\end{array}$ & $\begin{array}{l}\text { DONT } \\
\text { KNOW }\end{array}$ & $\begin{array}{ll}\text { Tabulat } \\
\text { ied(N) }\end{array}$ & 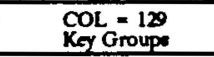 & $\begin{array}{l}\text { VERY } \\
\text { POSTIV }\end{array}$ & $\begin{array}{l}\text { SMWHT } \\
\text { POSTIV }\end{array}$ & NEUL: & $\begin{array}{l}\text { SMWHT } \\
\text { NEGTIV } \\
\text { NET }\end{array}$ & $\begin{array}{l}\text { VERY } \\
\text { NEGTIV }\end{array}$ & $\begin{array}{l}\text { DONT } \\
\text { KNOW }\end{array}$ \\
\hline 372 & ENTIRE SAMPLE & $13 \%$ & $9 \%$ & $8 \%$ & $13 \%$ & $55 \%$ & $2 \%$ & 379 & ENTRE SAMPLE & $11 \%$ & $6 \%$ & $11 \%$ & $12 \%$ & $99 \%$ & $1 \%$ \\
\hline $\begin{array}{r}182 \\
2 \\
106 \\
43 \\
8 \\
29\end{array}$ & $\begin{array}{l}\text { Married } \\
\text { Living a Married } \\
\text { Never Been Married } \\
\text { Divoroed } \\
\text { Separted } \\
\text { Widowed }\end{array}$ & $\begin{array}{l}12 \\
0 \\
13 \\
16 \\
0 \\
14\end{array}$ & $\begin{array}{l}7 \\
50 \\
7 \\
19 \\
13 \\
10\end{array}$ & $\begin{array}{c}7 \\
0 \\
6 \\
14 \\
13 \\
17\end{array}$ & $\begin{array}{l}13 \\
50 \\
14 \\
16 \\
13 \\
10\end{array}$ & $\begin{array}{l}60 \\
0 \\
58 \\
33 \\
33 \\
48\end{array}$ & $\begin{array}{l}2 \\
0 \\
3 \\
2 \\
0 \\
0\end{array}$ & $\begin{array}{r}185 \\
6 \\
112 \\
38 \\
7 \\
23\end{array}$ & $\begin{array}{l}\text { Married } \\
\text { Living a Married } \\
\text { Never Been Married } \\
\text { Divoroed } \\
\text { Separated } \\
\text { Widowed }\end{array}$ & $\begin{array}{l}12 \\
17 \\
8 \\
11 \\
14 \\
13\end{array}$ & $\begin{array}{r}7 \\
17 \\
4 \\
8 \\
0 \\
4\end{array}$ & $\begin{array}{c}11 \\
0 \\
13 \\
13 \\
0 \\
9\end{array}$ & $\begin{array}{l}11 \\
33 \\
13 \\
5 \\
29 \\
4\end{array}$ & $\begin{array}{l}58 \\
53 \\
61 \\
63 \\
57 \\
61\end{array}$ & ${ }_{0}^{1}$ \\
\hline $\begin{array}{r}0 \\
5 \\
22 \\
93 \\
131 \\
86 \\
35\end{array}$ & 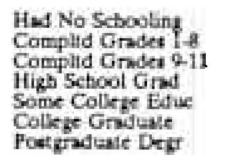 & $\begin{array}{l}0 \\
20 \\
14 \\
15 \\
11 \\
13 \\
9\end{array}$ & $\begin{array}{c}0 \\
0 \\
5 \\
13 \\
10 \\
6 \\
3\end{array}$ & $\begin{array}{l}0 \\
400 \\
5 \\
9 \\
8 \\
6 \\
9\end{array}$ & $\begin{array}{l}0 \\
20 \\
14 \\
11 \\
15 \\
14 \\
14\end{array}$ & $\begin{array}{l}00 \\
20 \\
55 \\
52 \\
53 \\
99 \\
63\end{array}$ & $\begin{array}{l}0 \\
0 \\
9 \\
1 \\
2 \\
2 \\
3\end{array}$ & $\begin{array}{r}0 \\
3 \\
25 \\
75 \\
145 \\
74 \\
50\end{array}$ & 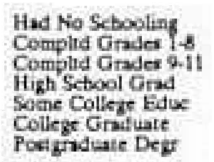 & $\begin{array}{l}0 \\
0 \\
12 \\
16 \\
10 \\
7 \\
10\end{array}$ & $\begin{array}{l}0 \\
0 \\
8 \\
7 \\
7 \\
7 \\
0\end{array}$ & $\begin{array}{l}0 \\
0 \\
12 \\
9 \\
12 \\
11 \\
12\end{array}$ & $\begin{array}{l}0 \\
97 \\
12 \\
9 \\
12 \\
11 \\
10\end{array}$ & $\begin{array}{l}0 \\
33 \\
48 \\
57 \\
57 \\
65 \\
68\end{array}$ & $\begin{array}{l}1 \\
0 \\
0\end{array}$ \\
\hline $\begin{array}{r}286 \\
21 \\
16 \\
3 \\
40\end{array}$ & $\begin{array}{l}\text { White } \\
\text { Blact } \\
\text { Asian } \\
\text { American Indian } \\
\text { Hirpenic }\end{array}$ & $\begin{array}{l}12 \\
14 \\
6 \\
33 \\
20\end{array}$ & $\begin{array}{l}9 \\
5 \\
6 \\
33 \\
10\end{array}$ & $\begin{array}{c}9 \\
5 \\
0 \\
33 \\
5\end{array}$ & $\begin{array}{l}13 \\
14 \\
19 \\
0 \\
15\end{array}$ & $\begin{array}{l}56 \\
62 \\
69 \\
0 \\
0\end{array}$ & $\begin{array}{l}2 \\
0 \\
0 \\
0 \\
5\end{array}$ & $\begin{array}{r}282 \\
36 \\
15 \\
7 \\
32\end{array}$ & $\begin{array}{l}\text { White } \\
\text { Black } \\
\text { Asian } \\
\text { American Indien } \\
\text { Hirpanic }\end{array}$ & $\begin{array}{r}11 \\
8 \\
13 \\
28 \\
3\end{array}$ & $\begin{array}{r}5 \\
11 \\
7 \\
0 \\
6\end{array}$ & $\begin{array}{r}11 \\
14 \\
7 \\
0 \\
9\end{array}$ & $\begin{array}{l}10 \\
19 \\
20 \\
0 \\
9\end{array}$ & $\begin{array}{l}60 \\
47 \\
73 \\
77 \\
72\end{array}$ & $\begin{array}{r}1 \\
0 \\
0 \\
14 \\
0\end{array}$ \\
\hline $\begin{array}{l}57 \\
97 \\
83 \\
38 \\
38 \\
57\end{array}$ & 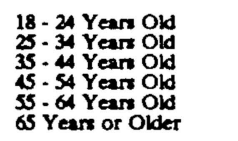 & $\begin{array}{l}9 \\
12 \\
11 \\
16 \\
18 \\
14\end{array}$ & $\begin{array}{c}7 \\
7 \\
11 \\
8 \\
3 \\
14\end{array}$ & $\begin{array}{c}2 \\
9 \\
7 \\
8 \\
13 \\
11\end{array}$ & $\begin{array}{l}16 \\
12 \\
14 \\
13 \\
11 \\
12\end{array}$ & $\begin{array}{l}61 \\
58 \\
55 \\
55 \\
53 \\
46\end{array}$ & $\begin{array}{l}5 \\
1 \\
1 \\
0 \\
3 \\
4\end{array}$ & $\begin{array}{l}96 \\
97 \\
94 \\
43 \\
27 \\
15\end{array}$ & 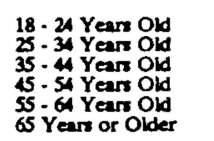 & $\begin{array}{l}11 \\
5 \\
11 \\
14 \\
11 \\
20\end{array}$ & $\begin{array}{r}2 \\
5 \\
7 \\
12 \\
0 \\
9\end{array}$ & $\begin{array}{l}15 \\
6 \\
11 \\
14 \\
19 \\
11\end{array}$ & $\begin{array}{r}14 \\
22 \\
3 \\
2 \\
15 \\
9\end{array}$ & $\begin{array}{l}56 \\
62 \\
68 \\
58 \\
56 \\
44\end{array}$ & $\begin{array}{l}3 \\
0 \\
0 \\
0 \\
0 \\
7\end{array}$ \\
\hline $\begin{array}{l}5 \\
30 \\
60 \\
67 \\
69 \\
39 \\
20 \\
34\end{array}$ & 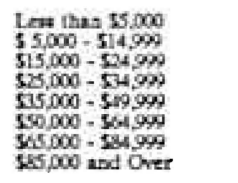 & $\begin{array}{l}0 \\
13 \\
17 \\
16 \\
13 \\
15 \\
4 \\
6\end{array}$ & $\begin{array}{l}20 \\
17 \\
12 \\
7 \\
1 \\
8 \\
4 \\
9\end{array}$ & $\begin{array}{c}20 \\
10 \\
8 \\
6 \\
9 \\
10 \\
0 \\
15\end{array}$ & $\begin{array}{l}0 \\
7 \\
13 \\
15 \\
10 \\
15 \\
27 \\
15\end{array}$ & $\begin{array}{l}60 \\
50 \\
47 \\
53 \\
54 \\
51 \\
62 \\
50\end{array}$ & $\begin{array}{l}0 \\
3 \\
3 \\
0 \\
3 \\
0 \\
1 \\
6\end{array}$ & $\begin{array}{l}8 \\
31 \\
53 \\
57 \\
74 \\
51 \\
29 \\
38\end{array}$ & 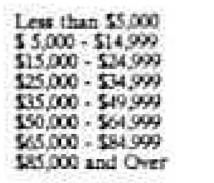 & $\begin{array}{l}13 \\
6 \\
17 \\
99 \\
14 \\
10 \\
14 \\
5\end{array}$ & $\begin{array}{l}0 \\
0 \\
8 \\
7 \\
9 \\
2 \\
0 \\
11\end{array}$ & $\begin{array}{r}0 \\
3 \\
13 \\
9 \\
8 \\
8 \\
12 \\
17 \\
11\end{array}$ & $\begin{array}{c}0 \\
19 \\
16 \\
16 \\
9 \\
18 \\
7 \\
8\end{array}$ & $\begin{array}{l}63 \\
68 \\
57 \\
58 \\
\$ 9 \\
99 \\
\$ 9 \\
98\end{array}$ & $\begin{array}{r}25 \\
\mathbf{3} \\
0 \\
0 \\
0 \\
0 \\
\mathbf{3} \\
\mathbf{3}\end{array}$ \\
\hline$\underset{201}{171}$ & $\underset{\text { Femalk }}{\text { Male }}$ & ${ }_{11}^{14}$ & $\stackrel{8}{9}$ & ${ }_{5}^{11}$ & ${ }_{11}^{16}$ & $\begin{array}{l}47 \\
62\end{array}$ & $i$ & 275 & $\begin{array}{l}\text { Male } \\
\text { Femak }\end{array}$ & ${ }_{8}^{13}$ & 9 & 15 & ${ }_{13}^{11}$ & $\stackrel{50}{\rightarrow}$ & 1 \\
\hline $\begin{array}{r}150 \\
117 \\
42\end{array}$ & $\begin{array}{l}\text { Republican } \\
\text { Democrat } \\
\text { Iodependent }\end{array}$ & $\prod_{11}^{11}$ & $\begin{array}{l}11 \\
6 \\
12\end{array}$ & $\begin{array}{r}13 \\
6 \\
7\end{array}$ & $\begin{array}{l}12 \\
16 \\
21\end{array}$ & $\begin{array}{l}53 \\
58 \\
48\end{array}$ & $\begin{array}{l}0 \\
3 \\
2\end{array}$ & $\begin{array}{c}160 \\
131 \\
22\end{array}$ & $\begin{array}{l}\text { Republican } \\
\text { Democeat } \\
\text { Independent }\end{array}$ & $\begin{array}{l}10 \\
8 \\
27\end{array}$ & $\begin{array}{l}6 \\
5 \\
5\end{array}$ & $\stackrel{99}{14}$ & $\begin{array}{c}11 \\
114 \\
0\end{array}$ & 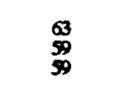 & $\begin{array}{l}1 \\
2 \\
0\end{array}$ \\
\hline $\begin{array}{l}26 \\
91 \\
115 \\
100 \\
28\end{array}$ & 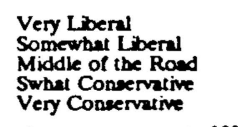 & $\begin{array}{l}12 \\
8 \\
14 \\
16 \\
11\end{array}$ & $\begin{array}{l}0 \\
2 \\
13 \\
12 \\
12 \\
4\end{array}$ & $\begin{array}{c}12 \\
8 \\
8 \\
9 \\
7\end{array}$ & $\begin{array}{l}15 \\
21 \\
10 \\
10 \\
32\end{array}$ & $\begin{array}{l}54 \\
99 \\
58 \\
51 \\
43\end{array}$ & $\begin{array}{l}8 \\
2 \\
1 \\
2 \\
4\end{array}$ & $\begin{array}{r}23 \\
85 \\
133 \\
102 \\
22\end{array}$ & 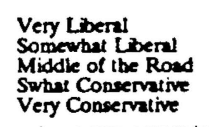 & $\begin{array}{r}4 \\
7 \\
11 \\
12 \\
23\end{array}$ & $\begin{array}{c}4 \\
4 \\
5 \\
10 \\
5\end{array}$ & $\begin{array}{c}17 \\
13 \\
11 \\
10 \\
5\end{array}$ & $\begin{array}{r}4 \\
8 \\
12 \\
10 \\
36\end{array}$ & $\begin{array}{l}65 \\
67 \\
99 \\
58 \\
27\end{array}$ & 1 \\
\hline ow per & centages sum scroes to 100 & \%. & & & & & & Row per & recateges sum ecroes to & 100\%. & & & & & \\
\hline \multicolumn{8}{|c|}{ National - Cities Survey } & \multicolumn{8}{|c|}{ National - States Survey } \\
\hline \multicolumn{8}{|c|}{$\begin{array}{l}\text { FEEUNGS ABOUT THE FRST THOUGHT OR IMAGE THAT COMES TO MIND } \\
\text { ABOUT AN UNDERGROUND NUCLAR WASTE REPOSTTORY }\end{array}$} & \multicolumn{8}{|c|}{$\begin{array}{l}\text { FEELINGS ABOUT THA FFRST THOUGHT OR IMAGE THAT COMES TO MIND } \\
\text { ABOUT AN UNDERGROUND NUCLEAR WASTE REPOSTIORY }\end{array}$} \\
\hline $\begin{array}{l}\text { Tabula- } \\
\text { ted(N) }\end{array}$ & $\begin{array}{l}\mathrm{COL}=120 \\
\text { Key Groupe }\end{array}$ & $\begin{array}{l}\text { VERY } \\
\text { POSTIV } \\
\end{array}$ & $\begin{array}{l}\text { SMWHT } \\
\text { POSTIV }\end{array}$ & $\begin{array}{l}\text { NEU- } \\
\text { TRAL }\end{array}$ & $\begin{array}{l}\text { SMWHT } \\
\text { NEGTIV }\end{array}$ & $\begin{array}{l}\text { VERY } \\
\text { NEGTIV }\end{array}$ & $\begin{array}{l}\text { DONT } \\
\text { KNOW } \\
\end{array}$ & $\begin{array}{l}\text { Tabula- } \\
\text { ted(N) }\end{array}$ & $\begin{array}{l}\operatorname{col}=18 \\
\text { Key Groups }\end{array}$ & $\begin{array}{l}\text { VERY } \\
\text { POSTIV } \\
\end{array}$ & $\begin{array}{l}\text { SMWHTT } \\
\text { POSTIV }\end{array}$ & NEU: & $\begin{array}{l}\text { SMWHT } \\
\text { NEGTIV }\end{array}$ & NERY & $\begin{array}{l}\text { DONT } \\
\text { KNOW }\end{array}$ \\
\hline 395 & ENTIRE SAMPLE & $20 \%$ & $9 \%$ & $9 *$ & $8 \%$ & $50 \%$ & $4 \%$ & 370 & ENTTRE SAMPLE & $14 \%$ & $6 x^{2}$ & $10 \pi$ & $9 \%$ & $59 \%$ & 26 \\
\hline $\begin{array}{r}229 \\
4 \\
96 \\
30 \\
6 \\
30\end{array}$ & $\begin{array}{l}\text { Married } \\
\text { Living as Maried } \\
\text { Never Been Married } \\
\text { Divorced } \\
\text { Separated } \\
\text { Widowed }\end{array}$ & $\begin{array}{l}19 \\
50 \\
22 \\
13 \\
17 \\
27\end{array}$ & $\begin{array}{l}7 \\
0 \\
7 \\
20 \\
33 \\
17\end{array}$ & $\begin{array}{r}10 \\
0 \\
5 \\
3 \\
0 \\
17\end{array}$ & $\begin{array}{r}10 \\
0 \\
7 \\
10 \\
0 \\
3\end{array}$ & $\begin{array}{l}50 \\
50 \\
56 \\
50 \\
50 \\
30\end{array}$ & $\begin{array}{l}4 \\
0 \\
2 \\
3 \\
0 \\
7\end{array}$ & $\begin{array}{r}217 \\
3 \\
86 \\
35 \\
5 \\
22\end{array}$ & $\begin{array}{l}\text { Married } \\
\text { Living as Married } \\
\text { Never Beeta Martied } \\
\text { Divorod } \\
\text { Separaled } \\
\text { Widowed }\end{array}$ & $\begin{array}{l}13 \\
0 \\
12 \\
14 \\
20 \\
23\end{array}$ & $\begin{array}{l}8 \\
0 \\
5 \\
0 \\
0 \\
9\end{array}$ & $\begin{array}{l}9 \\
0 \\
12 \\
3 \\
20 \\
14\end{array}$ & $\begin{array}{c}11 \\
0 \\
10 \\
3 \\
0 \\
5\end{array}$ & $\begin{array}{l}30 \\
100 \\
62 \\
60 \\
50\end{array}$ & $: 0$ \\
\hline $\begin{array}{r}1 \\
13 \\
38 \\
120 \\
103 \\
82 \\
38\end{array}$ & 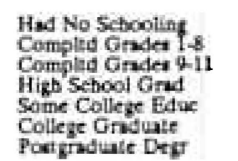 & $\begin{array}{l}0 \\
23 \\
2 \\
21 \\
18 \\
17 \\
18\end{array}$ & $\begin{array}{c}0 \\
15 \\
8 \\
13 \\
11 \\
2 \\
11\end{array}$ & $\begin{array}{c}0 \\
0 \\
11 \\
8 \\
10 \\
13 \\
3\end{array}$ & $\begin{array}{c}0 \\
0 \\
8 \\
5 \\
9 \\
12 \\
13\end{array}$ & $\begin{array}{l}100 \\
46 \\
42 \\
49 \\
48 \\
55 \\
53\end{array}$ & $\begin{array}{c}0 \\
15 \\
3 \\
5 \\
5 \\
0 \\
0\end{array}$ & $\begin{array}{l}0 \\
8 \\
31 \\
99 \\
97 \\
91 \\
42\end{array}$ & 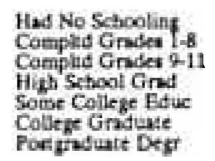 & $\begin{array}{l}0 \\
25 \\
10 \\
15 \\
15 \\
11 \\
12\end{array}$ & $\begin{array}{c}0 \\
0 \\
3 \\
8 \\
1 \\
12 \\
12\end{array}$ & $\begin{array}{r}0 \\
0 \\
10 \\
8 \\
5 \\
15 \\
14\end{array}$ & $\begin{array}{l}0 \\
0 \\
6 \\
9 \\
10 \\
9 \\
14\end{array}$ & $\begin{array}{l}0 \\
63 \\
71 \\
58 \\
66 \\
52 \\
52\end{array}$ & $\begin{array}{c}0 \\
13 \\
0 \\
2 \\
2\end{array}$ \\
\hline $\begin{array}{r}347 \\
28 \\
8 \\
4 \\
7\end{array}$ & $\begin{array}{l}\text { White } \\
\text { Blact } \\
\text { Asinn } \\
\text { American Indian } \\
\text { Hirpenic }\end{array}$ & $\begin{array}{l}19 \\
\underset{2}{19} \\
20 \\
\mathbf{2 0} \\
\mathbb{2}\end{array}$ & $\begin{array}{r}10 \\
7 \\
13 \\
0 \\
0\end{array}$ & $\begin{array}{c}9 \\
7 \\
13 \\
0 \\
0\end{array}$ & $\begin{array}{r}8 \\
7 \\
13 \\
25 \\
0\end{array}$ & $\begin{array}{l}50 \\
50 \\
38 \\
25 \\
5\end{array}$ & $\begin{array}{l}4 \\
0 \\
0 \\
14\end{array}$ & $\begin{array}{r}328 \\
17 \\
4 \\
2 \\
15\end{array}$ & $\begin{array}{l}\text { Whice } \\
\text { Blace } \\
\text { Asiva } \\
\text { Amerian Indien } \\
\text { Hispenic }\end{array}$ & $\begin{array}{l}14 \\
0 \\
25 \\
0 \\
7\end{array}$ & $\begin{array}{l}0 \\
0 \\
0 \\
0 \\
13\end{array}$ & $\begin{array}{l}10 \\
6 \\
25 \\
13 \\
13\end{array}$ & $\begin{aligned} 10 \\
0 \\
0 \\
0 \\
13\end{aligned}$ & $\begin{array}{r}58 \\
88 \\
50 \\
100 \\
53\end{array}$ & $\begin{array}{c}1 \\
12 \\
0 \\
0 \\
0\end{array}$ \\
\hline $\begin{array}{r}48 \\
114 \\
88 \\
35 \\
38 \\
52\end{array}$ & 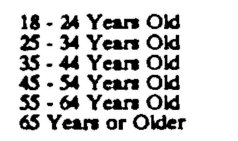 & $\begin{array}{l}21 \\
13 \\
11 \\
31 \\
24 \\
35\end{array}$ & $\begin{array}{c}2 \\
5 \\
16 \\
16 \\
5 \\
13 \\
15\end{array}$ & $\begin{array}{c}10 \\
11 \\
7 \\
99 \\
11 \\
6\end{array}$ & $\begin{array}{c}8 \\
9 \\
11 \\
11 \\
3 \\
4\end{array}$ & $\begin{array}{l}54 \\
61 \\
53 \\
36 \\
15\end{array}$ & $\begin{array}{l}4 \\
2 \\
7\end{array}$ & $\begin{array}{l}54 \\
93 \\
78 \\
73 \\
38 \\
52\end{array}$ & 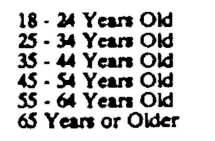 & $\begin{array}{l}25 \\
11 \\
15 \\
11 \\
21 \\
12\end{array}$ & $\begin{array}{r}4 \\
6 \\
5 \\
8 \\
8 \\
10\end{array}$ & $\begin{array}{r}7 \\
9 \\
10 \\
6 \\
8 \\
19\end{array}$ & $\begin{array}{c}7 \\
15 \\
9 \\
11 \\
5 \\
4\end{array}$ & $\begin{array}{l}16 \\
58 \\
58 \\
62 \\
55 \\
56\end{array}$ & \\
\hline $\begin{array}{l}17 \\
40 \\
67 \\
17 \\
28 \\
36 \\
2 \\
16\end{array}$ & 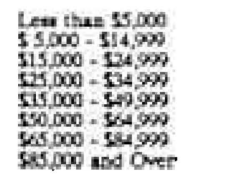 & $\begin{array}{l}18 \\
28 \\
22 \\
17 \\
17 \\
23 \\
22 \\
31\end{array}$ & $\begin{array}{c}12 \\
18 \\
12 \\
7 \\
10 \\
6 \\
9 \\
0\end{array}$ & $\begin{array}{l}6 \\
13 \\
3 \\
14 \\
11 \\
14 \\
17 \\
13\end{array}$ & $\begin{array}{c}6 \\
5 \\
9 \\
10 \\
10 \\
11 \\
9 \\
0\end{array}$ & $\begin{array}{l}53 \\
35 \\
46 \\
61 \\
54 \\
42 \\
43 \\
36\end{array}$ & $\begin{array}{l}6 \\
3 \\
7 \\
1 \\
2 \\
0\end{array}$ & $\begin{array}{l}7 \\
10 \\
66 \\
60 \\
74 \\
33\end{array}$ & 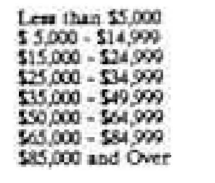 & $\begin{array}{l}14 \\
15 \\
11 \\
13 \\
116 \\
18 \\
4 \\
24\end{array}$ & $\begin{array}{r}14 \\
5 \\
3 \\
3 \\
7 \\
6 \\
17 \\
12\end{array}$ & $\begin{array}{c}0 \\
8 \\
11 \\
13 \\
5 \\
12 \\
9 \\
12\end{array}$ & $\begin{array}{c}14 \\
3 \\
99 \\
15 \\
5 \\
18 \\
9 \\
8\end{array}$ & $\begin{array}{l}57 \\
70 \\
64 \\
52 \\
55 \\
65 \\
61 \\
4\end{array}$ & 0 \\
\hline${ }_{228}^{167}$ & $\begin{array}{l}\text { Male } \\
\text { Female }\end{array}$ & 22 & $\stackrel{7}{11}$ & $\frac{11}{7}$ & ${ }_{6}^{11}$ & ${ }_{53}^{16}$ & $\begin{array}{l}3 \\
4\end{array}$ & $\begin{array}{l}172 \\
198\end{array}$ & $\begin{array}{l}\text { Make } \\
\text { Female }\end{array}$ & $\begin{array}{l}13 \\
14\end{array}$ & s & ${ }_{7}^{13}$ & 12 & 53 & $\frac{1}{3}$ \\
\hline $\begin{array}{l}131 \\
134 \\
40\end{array}$ & $\begin{array}{l}\text { Republican } \\
\text { Democrat } \\
\text { Independent }\end{array}$ & $\begin{array}{l}26 \\
17 \\
14\end{array}$ & $\begin{array}{c}14 \\
10 \\
2\end{array}$ & $\begin{array}{l}11 \\
8 \\
12\end{array}$ & $\begin{array}{c}8 \\
10^{8} \\
8\end{array}$ & $\begin{array}{l}40 \\
51 \\
61\end{array}$ & $\frac{2}{2}$ & $\begin{array}{l}122 \\
116 \\
55\end{array}$ & $\begin{array}{l}\text { Republican } \\
\text { Democrat } \\
\text { lndependent }\end{array}$ & i1 & $\begin{array}{c}4 \\
13 \\
13\end{array}$ & $\begin{array}{l}10 \\
\frac{10}{8} \\
13\end{array}$ & $\begin{array}{c}12 \\
10 \\
7\end{array}$ & $\begin{array}{l}57 \\
61 \\
35\end{array}$ & $\begin{array}{l}0 \\
2 \\
2\end{array}$ \\
\hline $\begin{array}{c}27 \\
74 \\
130 \\
113 \\
34 \\
\text { ow perc }\end{array}$ & 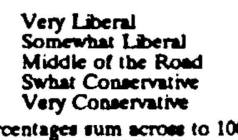 & $\begin{array}{l}11 \\
15 \\
17 \\
20 \\
38\end{array}$ & $\begin{array}{l}7 \\
11 \\
11 \\
15 \\
13\end{array}$ & $\begin{array}{l}1 \\
11 \\
8 \\
12 \\
6\end{array}$ & $\begin{array}{c}11 \\
5 \\
9 \\
10 \\
6\end{array}$ & $\begin{array}{l}56 \\
57 \\
52 \\
4 \\
35\end{array}$ & $\begin{array}{l}11 \\
1 \\
4 \\
3 \\
0\end{array}$ & $\begin{array}{c}20 \\
72 \\
131 \\
107 \\
21 \\
\text { Row pe }\end{array}$ & 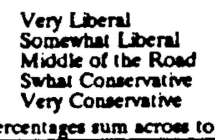 & $\begin{array}{l}25 \\
10 \\
17 \\
10 \\
14 \\
.\end{array}$ & $\begin{array}{r}0 \\
11 \\
8 \\
3 \\
14\end{array}$ & $\begin{array}{c}9 \\
9 \\
9 \\
16 \\
10\end{array}$ & $\begin{array}{c}5 \\
18 \\
70 \\
10 \\
5\end{array}$ & $\begin{array}{l}65 \\
56 \\
58 \\
\$ 9 \\
52\end{array}$ & $\begin{array}{l}0 \\
1 \\
2 \\
2 \\
5\end{array}$ \\
\hline
\end{tabular}


What Comes to Mind / 26

It appears that the repository has acquired the imagery of nuclear waste, through some process of transference--guilt by association. Will cities and states through which nuclear waste is transported and locations in which it is stored (or nearby) acquire these images as well? The transference is so natural, so powerful, that one state official involved in nuclear safety, upon hearing of our imagery results, indignantly accused us of having biased our respondents by calling the facility a "nuclear-waste repository."

Evidence that the quality of repository imagery has not been heretofore appreciated comes from exhortations by nuclear power proponents to please not use the term "dump" when referring to the repository, because of the obvious connotations or imagery this word conveys (see, e.g., Carter, 1987; p. 416). Not only is dump or garbage imagery relatively infrequent in the observed responses, such images would appear almost positive in comparison to the more prevalent responses.

\subsection{How Did It Get This Way?}

Imagery so strong and so impervious to influence from technical experts must have very potent origins. Weart's scholarly analysis of images shows that nuclear fears are deeply rooted in our social and cultural consciousness. He argues persuasively that modern thinking about nuclear energy employs beliefs and symbols that have been associated for centuries with the concept of transmutation--the passage through destruction to rebirth. In the early decades of the 20th century, transmutation images became centered on radioactivity, which was associated with

uncanny rays that brought hideous death or miraculous new life; with mad scientists and their ambiguous monsters'; with cosmic secrets of life and death; ... and with weapons great enough to destroy the world ..." [Weart, p.42]. 
What Comes to Mind / 27

But Weart's concept of transmutation has a duality that is hardly evident in the imagery we observed. Why has the evil overwhelmed the good? The answer undoubtedly involves the bombing of Hiroshima and Nagasaki which linked the dread images to reality. The sprouting of nuclear energy in the aftermath of the atomic bombing has led Smith (1988) to observe:

Nuclear energy was conceived in secrecy, born in war, and first revealed to the world in horror. No matter how much proponents try to separate the peaceful from the weapons atom, the connection is firmly embedded in the minds of the public. [Smith, p.62]

Research on nuclear imagery supports Smith's assertions. A study by Slovic, Lichtenstein, \& Fischhoff (1979) found that, even before the accident at Three Mile Island (TMI), people expected nuclear-reactor accidents to lead to disasters of immense proportions. When asked to describe the consequences of a "typical reactor accident," people's scenarios were found to resemble scenarios of the aftermath of nuclear war. Replication of these studies after the TMI event found even more extreme "images of disaster." ${ }^{3}$

Fiske, Pratto, \& Pavelchak (1983) studied public images of nuclear war using a method similar to that employed in the present study. Their results were remarkably similar to our repository images. The dominant themes of nuclear war were physical destruction (long-term, short-term, and immediate), death, injury, weapons, politics, hell, oblivion, nothingness, pain, contamination, radiation, end of civilization, and genetic damage.

3 The fact that the earliest technical risk assessments for nuclear power plants portrayed "worst-case scenarios" of tens of thousands of deaths and devastation over geographic areas the size of Pennsylvania (Ford, 1977) likely contributed to such extreme images. These early projections received enormous publicity, as in the movie The China Syndrome. 
What Comes to Mind / 28

Dominant emotional images included fear, terror, worry, and sadness, with anger, hate, helplessness, and peace mentioned somewhat less frequently. Much like images of a nuclear-waste repository, images of nuclear war were quite consensual and, for the most part, similar across persons differing in sex, race, political orientation, and education.

Additional evidence of the nuclear war- nuclear weapons-nuclear waste linkage comes from our the data of the present study. Respondents in the original Phoenix survey were asked, near the end of the interview, to free associate to the stimulus "nuclear test site." At the time of this writing we have not yet categorized these images in as precise a manner as we have categorized the repository images. However, it is clear that there is considerable overlap in content across the two image domains. The images "danger" and "dangerous" together occurred in $9.2 \%$ of the associations to the repository stimulus, compared to only $6.3 \%$ of the associations to the test site stimulus. The word "death" was given in $3.6 \%$ of the test site responses compared with $3.1 \%$ of the repository responses. Not surprisingly, there was much more imagery concerning bombs, war, and things military in association with the test site, although these were frequent responses to the repository stimulus as well.

The shared imagery of nuclear weapons, nuclear power, and nuclear waste may explain some of the surprising results that have come from surveys that have examined perceived risks for these various forms of nuclear hazards. A nuclear waste repository is judged to pose risks at least as great as a nuclear power plant or a nuclear weapons test site (Kunreuther, Desvousges, \& Slovic, 1988). If asked to indicate the closest distance a facility could be built from one's home before one would want to move to another place or actively 
What Comes to Mind / 29

protest, people are more averse to being near a nuclear waste repository than any other kind of facility studied, including a nuclear power plant (Flynn et al., 1990).

Further insights into the special quality of nuclear fear are provided by Erikson (1990), who draws attention to the broad, emerging theme of toxicity, both radioactive and chemical, that characterizes a "whole new species of trouble" associated with modern technological disasters. Erikson describes the special dread quality of technological accidents that expose people to radiation and chemicals in ways that "contaminate rather than merely damage; pollute, befoul, and taint rather than just create wreckage; penetrate human tissue indirectly rather than wound the surface by assaults of a more straightforward kind" (Erikson, p. 120). Erikson argues that these disasters have a malevolence that even the authors of Revelations would have found hard to imagine. Unlike natural disasters, they are unbounded. Unlike conventional disaster plots, they have no end. "Invisible contaminants remain a part of the surroundings--absorbed into the grain of the landscape, the tissues of the body and, worst of all, into the genetic material of the survivors. An 'all clear' is never sounded. The book of accounts is never closed" (p. 121).

\subsection{Will It Change?}

Unlike automobile accidents or natural disasters, to which people become accustomed and blasé, Erikson argues that radioactivity and other toxic substances are naturally loathsome, insidious horrors, which are unique in their capacity to induce a lasting sense of dread. Toxic emergencies, he says, "nourish dread" (p. 121).

There are other reasons to doubt that the images associated with nuclear waste repositories will soon change, even if there are no emergencies to nourish them. For one, 
What Comes to Mind / 30

there is an important cultural and educational institution that implants the images of radioactivity, transmutation, and evil into the minds of people at a particularly impressionable time of their lives--the comic book. Hendee (1990) describes an army of supervillians stalking the pages of Marvel Comics, all of whom owe their special capacities for evil to exposure to radiation. They include:

- Gargoyle, a Soviet scientific genius disfigured grotesquely in a nuclear weapons accident that also enhanced his intelligence.

Quicksand, a woman whose body has been converted entirely to a sand-like substance which she can shape at will as a result of exposure to a nuclear accident.

- Sunfire, a Japanese mutant with psychokinetic power to ionize matter as a result of being born to an invalid mother exposed years earlier to nuclear radiation in Hiroshima.

If there is a bright side to this phenomenon, it may be that there is a similar array of superheroes as well, who owe their capacities to encounters with radiation (e.g., Spiderman, bitten by a radioactive spider; and Texas Twister, a cowboy with superhuman ability to generate tornadoes as a result of accidental exposure to radioactivity during a tornado that stuck a radioactive waste storage facility in the Panhandle of Texas.' Most recently, a propitious encounter with nuclear waste has created the famous "teenage mutant Ninja turtles."

For those who have outgrown comics, the daily news media provide another form of experience that nourishes fears of nuclear-waste repositories. Most significant is the continuing story of decades of mishandling of wastes at the nation's military reactor sites, which has resulted in widespread leakage and contamination, projected to require more than 
What Comes to Mind / 31

$\$ 100$ billion for cleanup. In the background are smaller events, such as the recent announcement that the Russian republic has ordered a freeze on new atomic energy projects because the government cannot process and store radioactive wastes properly (RegisterGuard, 1990).

\subsection{Conclusion}

Nuclear waste exists and must be dealt with. Our analysis of 10,000 images shows that the great majority of the American public fears and loathes the concept of a nuclearwaste repository. The perceptions and emotions associated with a repository are psychologically, politically, socially, and economically important. In particular, the mechanisms of the human mind make it quite possible that places that become repositories for nuclear waste will also become stigmatized through associations with that dread substance. Decisions regarding the siting and management of nuclear waste storage facilities must be sensitive to these perceptions and emotions.

Erikson (1990) puts it well:

The one thing we cannot afford to assume as we consider how to deal with this new species of trouble is that the fear it evokes is either a passing whim or a fear that can be cooled by the calculations of experts. This dread has its own reasons; it must be respected" (p. 126). 
What Comes to Mind / 32

\subsection{References}

Campbell, A., Converse, P. E., Miller, W. E., \& Stokes, D. E. (1960). The American voter. NY: Wiley.

Carter, L. J. (1987). Nuclear imperatives and public trust. Washington, D.C.: Resources for the Future, Inc.

Cohen, B. L. (1983). Before it's too late: A scientist's case for nuclear energy. New York: Plenum.

Erikson, K. (1990). Toxic reckoning: Business faces a new kind of fear. Harvard Business Review, (Jan. - Feb.), 118-126.

Fiske, S. T., Pratto, F., \& Pavelchak, M. A. (1983). Citizens' images of nuclear war: Contents and consequences. Journal of Social Issues, 39, 41-65.

Ford, D. F. (1977). The history of federal nuclear safety assessment: From WASH 740 through the Reactor Safety Study. Cambridge, MA: Union of Concerned Scientists.

Flynn, J. H., Slovic, P., Mertz, C. K., \& Toma, J. (1990). Evaluations of Yucca Mountain. Technical Report: Carson City, Nevada. Nuclear Waste Project Office.

Freud, S. (1924). Collected papers. London: Hogarth.

Freeze of N-projects ordered. (1990, June 28). Register-Guard; Eugene, Oregon; p. 2.

Galton, F. (1880). Psychometric experiments. Brain, 2, 149-162.

Hamilton, D. L. (1981). Cognitive processes in stereotyping and intergroup behavior. Hillsdale, NJ: Erlbaum. 
What Comes to Mind / 33

Hendee, W. R. (1990, February). Terror and dread in the perception of radiation. Paper presented at the 23rd mid-year meeting of the Health Physics Society, Atlantic City, NJ.

Kraft, M., \& Dunlap, R. (In press). The public and nuclear waste: Socio-political dimensions of repository siting. Durham, NC: Duke University Press.

Kunreuther, H., \& Easterling, D. (1990). Imagery and convention decision making. Paper in preparation.

Kunreuther, H., Desvousges, W. H., \& Slovic, P. (1988). Nevada's predicament: Public perceptions of risk from the proposed nuclear waste repository. Environment, 30(8), $16-20,30-33$.

Lifton, R. J. (1967). Death in life. New York: Basic Books.

Mountain West Study Team. (1989). An interim report on the state of Nevada socioeconomic studies. Carson City, Nevada: Nevada Nuclear Waste Project Office. Report NWPO-SE-024-89, June.

Nealey, S. M., \& Herbert, J. A. (1983). Public attitudes toward radioactive wastes. In C. A. Walker, L. C. Gould, \& E. J. Woodhouse (Eds.), Too hot to handle: Social and policy issues in the management of radioactive wastes (pp. 94-111). New Haven: Yale University Press.

Slovic, P., Layman, M., \& Flynn, J. H. (1990). Images of a place and vacation preferences: Report of the 1989 surveys. Technical Report: Carson City, Nevada. Nuclear Waste Project Office. 
What Comes to Mind / 34

Slovic, P., Layman, M., Kraus, N., Chalmers, J., Gesell, G., \& Flynn, J. (1989). Perceived risk, stigma, and potential economic impacts of a high-level nuclear waste repository in Nevada. Eugene, Oregon: Decision Research Report 89-3.

Slovic, P., Lichtenstein, S., \& Fischhoff, B. (1979). Images of disaster: Perception and acceptance of risks from nuclear power. In G. Goodman \& W. Rowe (Eds.), Energy risk management (pp. 223-245). London: Academic Press.

Smith, K. R. (1988). Perception of risks associated with nuclear power. Energy Environment Monitor, 4(1), 61-70.

Szalay, L. B., \& Deese, J. (1978). Subjective meaning and culture: An assessment through word associations. Hillsdale, NJ: Erlbaum.

Technical Review Committee. (1990). Interim statement on the Yucca Mountain socioeconomic project. Carson City, Nevada: Nevada Nuclear Waste Project Office.

Weart, S. R. (1988). Nuclear fear: A history of images. Cambridge: Howard University Press.

Weinberg, A. M. (1989). Public perceptions of hazardous technologies and democratic political institutions. Paper presented at Waste Management '89, Tucson, Arizona. Wundt, W. (1883). Uber psychologische methoden. Philosophische Studien, 1, 1-38. 


\section{NEGATIVE CONSEQUENCES}

\section{b. Death / Sickness}

\begin{aligned} & 306 DEATH \\ & 120 CANCER \\ & 42 SICKNESS \\ & 39 UNHEALTHY \\ & 31 DISEASE \\ & 22 ILINESS \\ & 13 HEALTH HAZARD \\ & 12 BIRTH DEFECTS \\ & 12 DISEASES \\ & 9 DEATHS \\ & 8 DYING \\ & 7 SICK \\ & 6 HEALTH PROBLEMS \\ & 6 SICK PEOPLE \\ & 5 BAD FOR HEALTH \\ & 5 BURIAL \\ & 5 KILING \\ & 5 MUTATIONS \\ & 5 NO LIFE \\ & 4 DEAD \\ & 4 DEFORMITIES \\ & 4 LEUKEMLA \\ & 4 MUTANTS \\ & 3 HAIR FALLING OUT \\ & 3 HEALTH HAZARDS \\ & 3 PEOPLE GETTING SICK \\ & 2 BAD HEALTH \\ & 2 CANCER CAUSING \\ & 2 DEAD PEOPLE \\ & 2 DEFORMED CHILDREN \\ & 2 HAZARDOUS TO HEALTH \\ & 2 HEALTH RISKS \\ & 2 INFECTION \\ & 2 LESIONS \\ & 2 MUTTTION \\ & 2 NOT HEALTHY \\ & 2 PEOPLE DYING \\ & 2 POOR HEALTH \\ & \\ & \hline\end{aligned}

\author{
1 BABIES BEING BORN MUTATED \\ 1 BABIES WTTH THREE HEADS \\ 1 BAD FOR HEALTH, LETHAL \\ 1 BAD HEALTH PROBLEMS \\ 1 BIRTH DEFECTS FROM LONG EXPOSURE \\ 1 CANCEROUS \\ 1 CAUSE CANCER \\ 1 CAUSES CANCER \\ 1 CHILDREN AND DEATH \\ 1 CHILDREN, DYING \\ 1 DANGER TO HEAL.TH \\ 1 DANGEROUS CANCER \\ 1 DANGEROUS TO HEALTH \\ 1 DEAD KIDS \\ 1 DEAD STUFF \\ 1 DEAD THINGS \\ 1 DEAD TREES \\ 1 DEATH AND SICKNESS \\ 1 DEATHLY \\ 1 DEFORMED \\ 1 DEFORMED KIDS \\ 1 DEFORMITIES IN RABIES \\ 1 DEFORMITY \\ 1 DEGENERATTVE \\ 1 DESTROYING OUR HEALTH \\ 1 DETERIORATING HEALTH \\ 1 DIE \\ 1 DISEASE CAUSER \\ 1 DISFTGUREMENT \\ 1 FATAL \\ 1 FATALITIES \\ 1 GENETIC DAMAGE \\ 1 GENETIC DEFECTS \\ 1 GRAVES \\ 1 HAIR LOSS \\ 1 HAZARD FOR HEALTH \\ 1 HAZARDOUS TO YOUR HEALTH

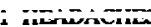

\author{
1 HEALTH PROBLEM \\ 1 HEALTH RISK \\ 1 HIGH CANCER RISK \\ 1 ILL-HEALTH \\ 1 INCREASED DISEASE \\ 1 IT'S NOT GOOD FOR YOU \\ 1 KILL HUMAN BEINGS \\ 1 KILLLER \\ 1 KILLING ALL OF US \\ 1 KILLING PEOPLE \\ 1 KILLNG US \\ 1 KLLS \\ 1 LETHAL DEATH \\ 1 LJFELESS \\ 1 MANY SIDE EFFECTS AND DISEASE \\ 1 MODERATE HEALTH PROBLEM \\ 1 MORE DEATH \\ 1 NERVOUS DISORDER \\ 1 NO LIFE FORMS \\ 1 NOT LIVE \\ 1 PEOPLE COULD BECOME INFECTED \\ 1 PEOPLE LOSING THEIR HAIR \\ 1 PEOPLE SICK \\ 1 PEOPLES HEALTH \\ 1 PREMATURE DEATH \\ 1 RADHTION CANCER \\ 1 RESPIRATORY PROBLEMS \\ 1 RETARDED KIDS \\ 1 ROTITNG FLESH \\ 1 SHORT HEALTH \\ 1 SHORT LIFE \\ 1 SKIN DISEASE \\ 1 SLOW DEATH \\ 1 STERILITY \\ 1 TERRIBLE FOR HEALTH \\ 1 TERRIBLE SICKNESS \\ 1 THREATENING TO LIFE \\ 1 UNHEALTHY CONDITIONS
}


APPENDIX - Page 3

\section{NEGATIVE CONSEQUENCES}

\section{c. Environmental Damage}

\begin{tabular}{|c|c|}
\hline 276 & POLLUTION \\
\hline 134 & CONTAMINATION \\
\hline 20 & WATER POLLUTION \\
\hline 13 & WATER CONTAMINATION \\
\hline 10 & POLLUTION, WATER \\
\hline 8 & CONTAMINATED WATER \\
\hline 7 & LOVE CANAL \\
\hline 4 & BAD WATER \\
\hline 4 & EROSION \\
\hline 3 & BAD ENVIRONMENT \\
\hline 3 & BAD FOR ENVIRONMENT \\
\hline 3 & CONTAMINATION, WATER \\
\hline 3 & ENVIRONMENTAL HAZARD \\
\hline 3 & POLLUTED \\
\hline 3 & POLLUTING WATER \\
\hline 3 & POLLUTION OF WATER \\
\hline 3 & POLLUTION, AIR \\
\hline 3 & WATER, BAD \\
\hline 2 & BAD FOR NATURE \\
\hline 2 & BAD SOIL \\
\hline 2 & CONTAMINATED \\
\hline 2 & CONTAMINATING \\
\hline 2 & CONTAMINATION OF THE GROUND \\
\hline 2 & CONTAMINATION OF WATER \\
\hline 2 & DESTROYING NATURE \\
\hline 2 & DIRTY WATER \\
\hline 2 & ENVIRONMENTAL DESTRUCTION \\
\hline 2 & ENVIRONMENTAL, POLLUTION \\
\hline 2 & ENVIRONMENTAL PROBLEMS \\
\hline 2 & ENVIRONMENTALLY UNSAFE \\
\hline 2 & FORM OF POLLUTION \\
\hline 2 & GROUND POLLUTION \\
\hline 2 & GROUND WATER CONTAMINATION \\
\hline 2 & HARMFUL TO ENVIRONMENT \\
\hline 2 & LAND POLLUTION \\
\hline 2 & POLLUTED WATER \\
\hline 2 & POLLUTION IN THE WATER \\
\hline 1 & ACID RAIN \\
\hline 1 & AFFECT THE STREAMS \\
\hline 1 & ALL THE LAND WOULD BE NO GOOD \\
\hline 1 & ANIMALS DYING \\
\hline 1 & BAD AIR \\
\hline 1 & BAD DRINKING WATER \\
\hline 1 & BAD ENVIRONMENTAL \\
\hline 1 & BAD FOR WATER \\
\hline 1 & BAD POLLUTION \\
\hline 1 & BIG POLLUTION ISSUE \\
\hline 1 & BRINE MIGRATION \\
\hline 1 & CONTAMINATE GROUND WATER \\
\hline 1 & CONTAMINATE THE WATER LEVEL \\
\hline 1 & CONTAMINATED AREA \\
\hline 1 & CONTAMINATED MINERALS \\
\hline 1 & CONTAMINATED SOIL \\
\hline 1 & CONTAMINATES \\
\hline 1 & CONTAMINATES AIR \\
\hline 1 & CONTAMINATES THE WATER \\
\hline 1 & CONTAMINATING THE WATER SUPPLY \\
\hline 1 & CONTAMINATING WATER \\
\hline 1 & CONTAMINATION OF ALL SORTS \\
\hline 1 & CONTAMINATION OF FOODS \\
\hline 1 & CONTAMINATION OF THE SOIL \\
\hline 1 & CONTAMINATION, GROUND \\
\hline 1 & COULD CONTAMINATE WATER \\
\hline
\end{tabular}
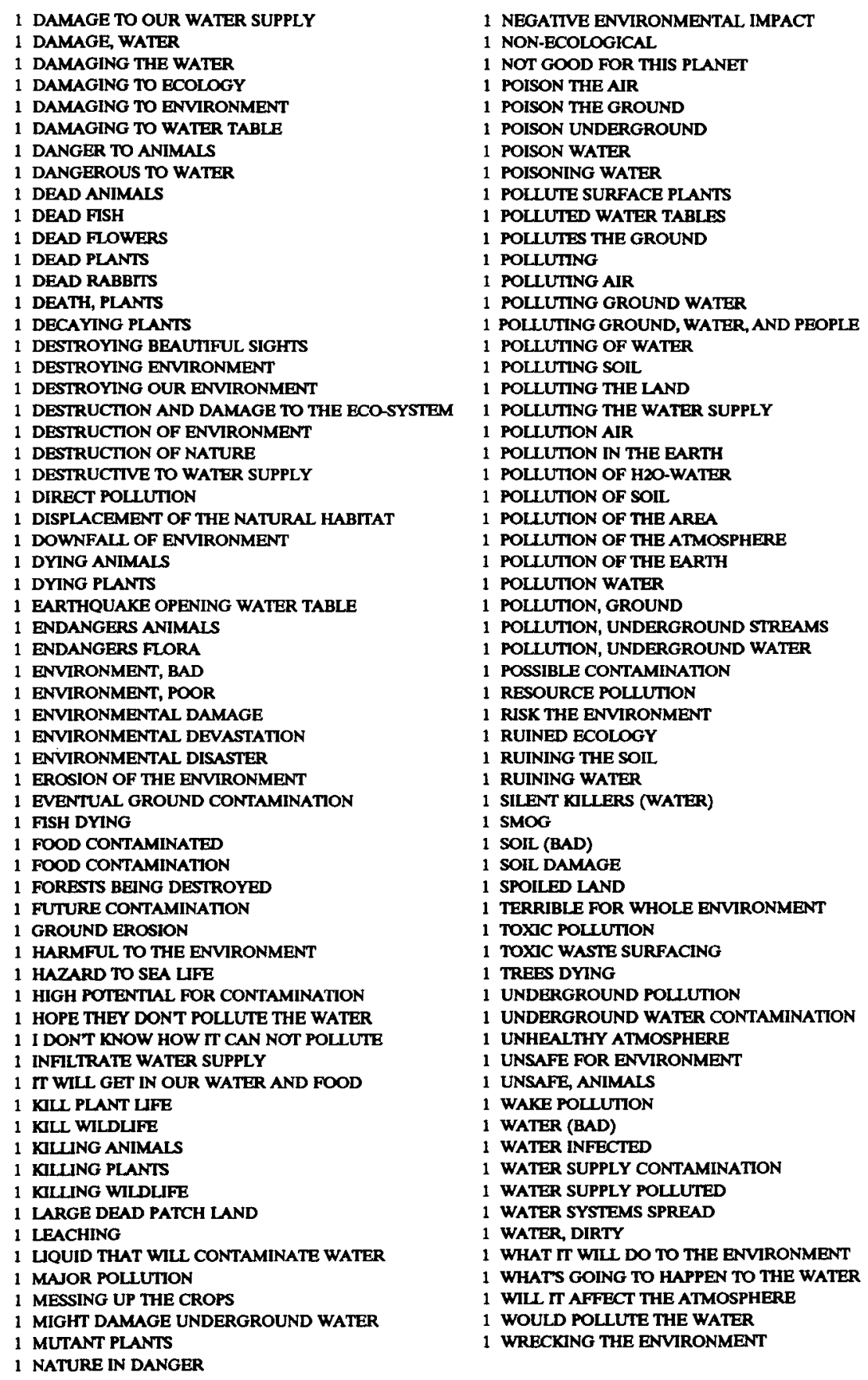

TOTAL Frequency for Category: 692 (6.92\%) 


\section{NEGATIVE CONSEQUENCES}

\section{d. Leakage}

$\begin{array}{ll}106 & \text { LEAKAGE } \\ 24 & \text { SEEPAGE } \\ 13 & \text { LEAKS } \\ 9 & \text { SPILLAGE } \\ 7 & \text { LEAK } \\ 6 & \text { SPILLS } \\ 3 & \text { LEAKING } \\ 3 & \text { LEAKY BARRELS } \\ 2 & \text { LEAKING BARRELS } \\ 1 & \text { BARREIS DETERIORATE \& WASTE SEEPS OUT } \\ 1 & \text { BREAKING OUT OF GROUND } \\ 1 & \text { CHECK FOR LEAKAGE } \\ 1 & \text { COMES UP } \\ 1 & \text { COMING OUT OF GROUND } \\ 1 & \text { COMING TO SURFACE } \\ 1 & \text { COULD TT BE SEALED SO NOTHING ESCAPES } \\ 1 & \text { ERUPTS THROUGH EARTH } \\ 1 & \text { EVENTUALLY LEAK }\end{array}$

$\begin{array}{ll}1 & \text { GET INTO WATER SUPPLIES } \\ 1 & \text { GETS INTO WATER } \\ 1 & \text { GETTING INTO THE WATER \& FUCKING US UP } \\ 1 & \text { GETTING INTO WATER } \\ 1 & \text { GROUND LEAKAGE } \\ 1 & \text { IT WOULD LEAK } \\ 1 & \text { ITS GOING TO SEEP OUT } \\ 1 & \text { LEAK INTO WATER SUPPLY } \\ 1 & \text { LEAKAGE DANGER } \\ 1 & \text { LEAKAGE IN AQUIFERS } \\ 1 & \text { LEAKAGE INTO GROUND WATER } \\ 1 & \text { LEAKAGE INTO WATER SUPPLY } \\ 1 & \text { LEAKAGE, SEEPAGE } \\ 1 & \text { LEAKAGE, WASTE } \\ 1 & \text { LEAKAGE, WATER } \\ 1 & \text { LEAKING CONTAINERS } \\ 1 & \text { LEAKING INTO WATER } \\ 1 & \text { LEAKING SEWAGE }\end{array}$

1 POISON OF WATER LEAKAGE

1 POSSIBILITY FOR LEAKS

1 POSSIBLE LEAKAGE

1 SEEP INTO WATER

1 SEEPAGE COMING OUT

1 SEEPAGE INTO WATER

1 SEEPAGE INTO WATER TABLE

1 SEEPAGE, ATMOSPHERE

SEEPING THROUGH

1 SPILL

1 SPILLAGE, CHEMICALS

1 THINGS COMING UP OUT OF THE GROUND

1 WASTE WIL ESCAPE AND GET INTO GROUND

1 WATER, LEAKAGE

1 WILL IT EVER COME UP

WOULD SCATTER WTH FLOOD

TOTAL Frequency for Category: 216 (2.16\%)

\section{e. Destruction}

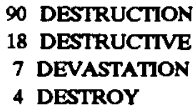

90 DESTRUCTION

18 DESTRUCTIVE

7 DEVASTATION

4 DESTROY

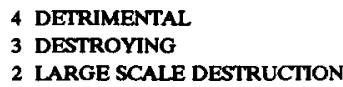

1 DELAYED DESTRUCTION

\author{
1 DESTROYS SO MUCH \\ 1 DESTROYS THE GROUND \\ 1 DESTRUCTION OF THE LANDSCAPE \\ 1 DEVASTATING
}

TOTAL Frequency for Category: 133 (1.33\%)

f. Pain and Suffering

5 PAIN

5 SUFFERING

4 PAINFUL

\author{
1 A LOT OF PAIN \\ 1 AGONY \\ 1 MISERY
}

1 PEOPLE SUFFERING

TOTAL Frequency for Category: $18(0.18 \%)$

\section{g. Uninhabitable}

1 NO PEOPLE

1 NO VEGETATION

1 NO WATER

1 YOU CANT LIVE THERE
1 NOTHING CAN GROW

1 NOTHING LEF

1 UN-LIVABLE

TOTAL Frequency for Category: $7(0.07 \%)$

\section{h. Local Repository Area Consequences}
1 AREA THAT CAN NEVER BE USED AGAIN
1 LOCAL DAMAGE
1 UNBUILDABLE LAND
1 KILLING THE AREA OFF
1 NO FOOD PRODUCTS FROM THAT AREA
1 UNUSABLE LAND

TOTAL Frequency for Category: $6(0.06 \%)$

i. Negative Consequences - Other

$\begin{array}{ll}1 \text { CONTAMINATED CLOTHING } & 1 \text { NO FRESH FOODS } \\ 1 \text { HUMAN LIVES WASTED } & 1 \text { NO MORE SUNSHINE } \\ 1 \text { MIGHT CAUSE ANOTHER EARTHQUAKE } & 1 \text { NO PLACE SAFE }\end{array}$

1 STERILE FARM ANIMALS

TOTAL Frequency for Category: $8(0.08 \%)$ 


\section{NEGATIVE}

a. Bad / Negative

\begin{tabular}{|c|c|}
\hline $\begin{array}{l}88 \\
45\end{array}$ & $\begin{array}{l}\text { BAD } \\
\text { NEGATTVE }\end{array}$ \\
\hline 397 & TERRIBLE \\
\hline 335 & STUPID \\
\hline 251 & DIRTY \\
\hline $18 \mathrm{t}-(-3)-$ & UGLY \\
\hline $17 \mathrm{~s}$ & NOT GOOD \\
\hline $17 \mathrm{C}$ & UNDESIRABLE \\
\hline $15 \mathrm{I}$ & DISGUSTING \\
\hline $14 \mathrm{I}$ & DONT LIKE IT \\
\hline $13 c$ & GROSS \\
\hline $11 \mathrm{I}$ & DUMB \\
\hline & STUPIDITY \\
\hline $9 y$ & YUCK \\
\hline $8 \mathrm{D}$ & DISLIKE \\
\hline $7 \mathrm{~A}$ & ANGER \\
\hline $7 \mathrm{~B}$ & BAD NEWS \\
\hline $7 \mathrm{~N}$ & MESS \\
\hline $7 \mathrm{U}$ & UNPLEASANT \\
\hline $7 \mathrm{v}$ & VERY NEGATTVE \\
\hline $6 \mathrm{C}$ & CRAZY \\
\hline $6 \mathrm{R}$ & RIDICULOUS \\
\hline $5 A$ & AWFUL \\
\hline $5 \mathrm{~F}$ & FILTH \\
\hline $5 \mathrm{~N}$ & NASTY \\
\hline & $\begin{array}{l}\text { DEPRESSING } \\
\text { DISGUST }\end{array}$ \\
\hline $4 \mathrm{D}$ & DONT CARE FOR IT \\
\hline & DONT LIKE \\
\hline $4 \mathrm{H}$ & HIDEOUS \\
\hline & I DONT LIKE IT \\
\hline $\begin{array}{l}4 N \\
4 S\end{array}$ & NO GOOD \\
\hline & $\begin{array}{l}\text { SAD } \\
\text { UNCLEAN }\end{array}$ \\
\hline 3 B & BULLSHIT \\
\hline $3 \mathbf{E}$ & EVIL \\
\hline $3 \mathrm{H}$ & HELL \\
\hline & ITS BAD \\
\hline $3 \mathrm{Jt}$ & JUNK \\
\hline $3 \mathrm{M}$ & MESSY \\
\hline $3 \mathrm{~s}$ & SHIT \\
\hline $3 \mathrm{sI}$ & SICKENING \\
\hline $3 \mathrm{U}$ & UNCOMFORTABLE \\
\hline $3 \mathrm{U}$ & UNDESIREABLE \\
\hline & ABOMINATION \\
\hline $2 \mathrm{~A}$ & ANGRY PEOPLE \\
\hline $2 \mathrm{D}$ & DESPAIR \\
\hline $2 \mathrm{D}$ & DISTASTE \\
\hline $2 \mathbf{F}$ & FRUSTRATION \\
\hline $2 \mathrm{II}$ & I DONT LIKE THE IDEA \\
\hline & I HATE IT \\
\hline 2 Is & INSANE \\
\hline 2 IN & INSANITY \\
\hline $2 \mathrm{~N}$ & NOT HAPPY \\
\hline $2 \mathrm{~N}$ & NOT PLEASANT \\
\hline $2 \mathrm{~N}$ & NOT RIGHT \\
\hline & NOT VERY GOOD \\
\hline $2 \mathbf{P}$ & PATHETIC \\
\hline $2 \mathbf{R}$ & REPULSIVE \\
\hline $2 \mathrm{U}$ & UNATTRACTTVE \\
\hline $2 \mathrm{U}$ & UNCIVILIZED \\
\hline $2 \mathrm{U}$ & UNETHICAL \\
\hline & UNFORTUNATE \\
\hline $2 \mathrm{U}$ & UNHAPPY \\
\hline & UNINTELLIGENT \\
\hline $2 \mathrm{U}$ & UNSIGHTLY \\
\hline & A HELL \\
\hline & $\begin{array}{l}\text { A MESS } \\
\text { ABHORRENCE }\end{array}$ \\
\hline & ANGRY \\
\hline & $\begin{array}{l}\text { ASININE } \\
\text { BAD BAD BAD }\end{array}$ \\
\hline
\end{tabular}
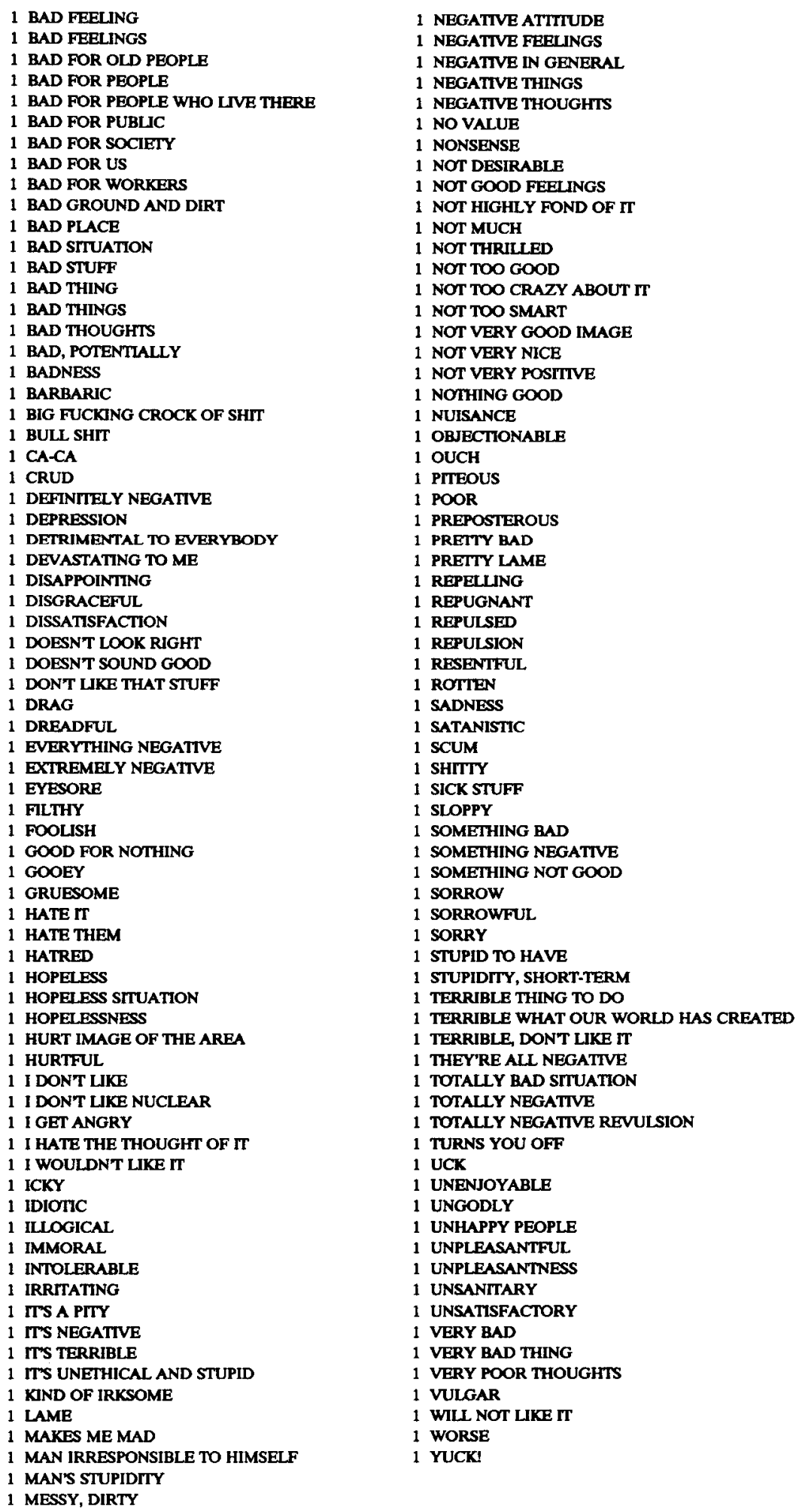

TOTAL Frequency for Category: 681 (6.81\%) 


\section{NEGATIVE}

b. Scary

$\begin{array}{ll}107 & \text { SCARY } \\ 77 & \text { FEAR } \\ 35 & \text { FRIGHTENING } \\ 26 & \text { HORRIBLE } \\ 15 & \text { SCARED } \\ 11 & \text { CONCERN } \\ 8 & \text { HORROR } \\ 7 & \text { AFRAID } \\ 6 & \text { FEARFUL } \\ 6 & \text { PANIC } \\ 6 & \text { WORRY } \\ 5 & \text { CONCERNED } \\ 5 & \text { TERROR } \\ 5 & \text { WORRIED } \\ 4 & \text { APPREHENSION } \\ 4 & \text { FRIGHTENED } \\ 4 & \text { NERVOUS } \\ 4 & \text { SCARES ME } \\ 3 & \text { INSECURE } \\ 3 & \text { TERRIFYING } \\ 2 & \text { ANXIETY } \\ 2 & \text { FRIGHT } \\ 2 & \text { GENERAL CONCERN } \\ 2 & \text { HORRIFYING } \\ 2 & \text { NIGHTMARE }\end{array}$

\author{
2 UNEASY \\ 1 A LITTLE FRIGHTENING IMAGE \\ 1 ALWAYS BE WORRIED \\ 1 DEEPP CONCERN \\ 1 FEAR FOR NEW GENERATIONS \\ 1 FEAR OF DYING \\ 1 FEAR OF LEAKS OR EXPLOSION \\ 1 FEAR OF UNKNOWN CONSEQUENCES \\ 1 FOREBODING \\ 1 FRIGHTFUL \\ 1 GOOD GRIEF \\ 1 GOOD HEAVENS \\ 1 HEAVEN HELP US \\ 1 HOLY SHIT \\ 1 HORRID \\ 1 HORRIFIED \\ 1 I AM CONCERNED \\ 1 ITS FEARFUL \\ 1 MISGIVINGS \\ 1 OH BOY \\ 1 OH GOD \\ 1 OH SHIT \\ 1 OH, MY GOD! \\ 1 OH, MY GOODNESS \\ 1 OMINOUS
}

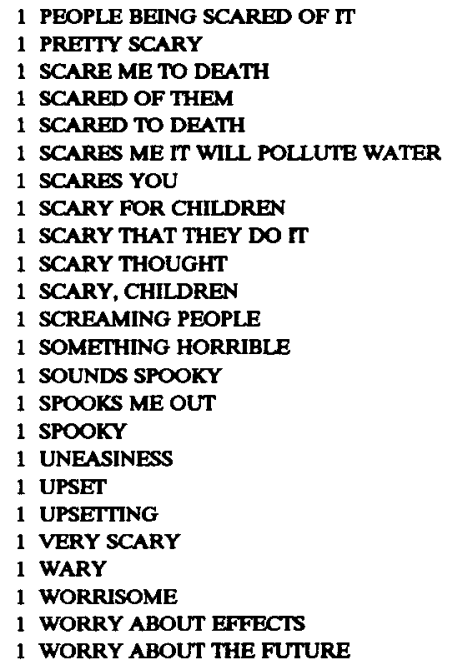

TOTAL Frequency for Category: 401 (4.01\%)

\section{c. Unnecessary / Opposed}

41 UNNECESSARY

20 UNWANTED

$16 \mathrm{NO}$

13 WRONG

11 BAD IDEA

9 WASTEFUL

8 WASTE OF MONEY

7 USELESS

6 UNACCEPTABLE

6 WASTE OF LAND

5 AGAINST IT

5 AVOID

5 DONT WANT IT

5 NOT A GOOD IDEA

5 NOT NECESSARY

4 AGAINST

4 DONT WANT

3 DONT NEED IT

3 GET RID OF $\mathrm{IT}$

3 NEEDLESS

3 OPPOSED

3 OPPOSTIION

3 SHOULDNT BE

2 DONT AGREE

2 I AM AGAINST IT

2 I DONT WANT IT

2 NEVER

2 NOT FOR IT

2 NOT IN FAVOR OF IT

2 NOT NEEDED

2 SHOULD BE BANNED

2 SHOULDNT BE THERE

2 SHOULDNT DO IT

2 SHOULDNT EXIST

2 SHOULDNT HAVE IT

2 UNNEEDED

2 UNPROVEN

2 WASTED LAND

2 WE DONT NEED IT

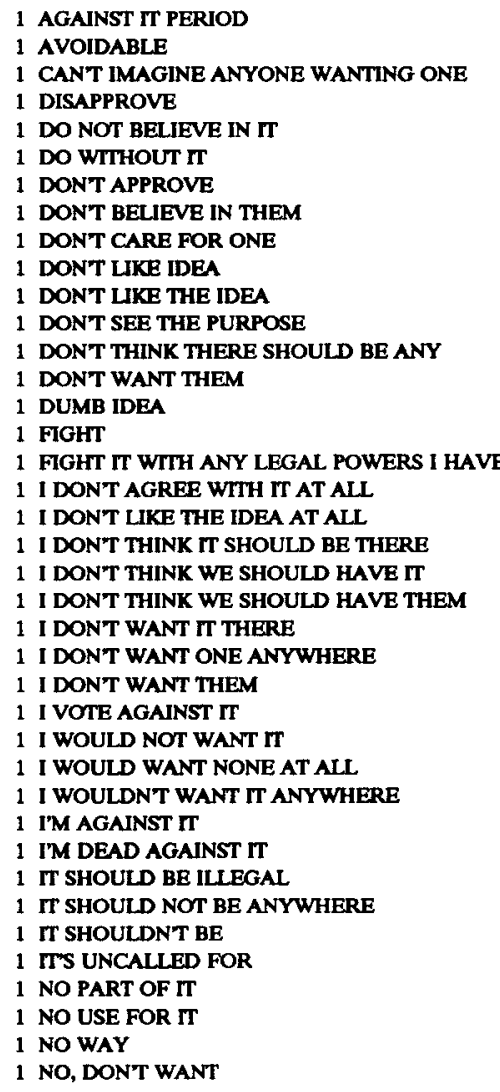

1 NO-LIFE

1 NOT FAVOR IT

1 NOT FOR ME

1 NOT HAVE IT

1 NOT IN FAVOR

1 NOT LETTING IT HAPPEN

1 NOT SOMETHING YOU WANT TO HAVE AROUND

1 NOT TO BE DONE

1 NOT TO DO IT

1 NOT WANTED

1 REAGAN WASTING THE MONEY

1 SHOULDNT BE ANY

1 SHOULDNT BE ANYWHERE

1 SHOULDNT BE IN THE FIRST PLACE

1 SHOULDNT EVEN BE THERE

1 SHOULDN'T EXIST AROUND US

1 SHOULDNT HAVE

1 SHOULDNT HAVE THEM

1 THEY OUGHT TO DO AWAY WITH IT

1 THEY SHOULD NOT EXIST

1 THEY SHOULDNT BE

1 TO BE AVOIDED

1 TO GET RID OF

1 TOTAL WASTE OF GOVERNMENT MONEY

1 UNNECESSARY EVIL

1 UNNECESSARY THREAT TO HEALTH AND LIFE

1 USELESSNESS

1 VERY FOOLISH, NO NEED

1 VERY POOR IDEA

1 WASTE MONEY

1 WASTE OF EVERYONES TIME

1 WASTE OF TAX DOLLARS

1 WASTE OF TIME

1 WASTE, TIME \& MATERIAI

WASTED MONEY

1 WOULDNT WANT

1 WOULDNT WANT IT

TOTAL Frequency for Category: 296 (2.96\%) 


\section{NEGATIVE}

\section{d. Not Near Me}

25 FAR AWAY

8 WOULDNT WANT TO LIVE NEAR ONE

6 SOMEWHERE EISE

5 AWAY FROM ME

5 MOVE

5 STAY AWAY

5 WOULDNT WANT TO LIVE NEAR IT

5 WOULDNT WANT TO LIVE THERE

4 AWAY

4 DON'T WANT IT HERE

4 MOVING

4 NOT HERE

4 WOULDNT WANT TO BE THERE

3 DONT WANT IT NEAR ME

3 I DONT WANT TO BE NEAR IT

3 NOT AROUND ME

3 WOULDNT WANT IT NEAR ME

3 WOULDNT WANT TO BE NEAR ONE

3 WOULDNT WANT TO LIVE NEAR

2 AVOIDANCE

2 DONT WANT TO BE NEAR IT

2 DON'T WANT TO LIVE NEAR IT

2 DONT WANT TO LIVE THERE

2 FAR AWAY AS POSSIBLE

2 FAR AWAY FROM ME

2 I DONT WANT IT NEAR ME

2 I WOULDNT WANT IT NEAR ME

2 I WOULDNT WANT TO LIVE NEAR IT

2 I WOULDN'T WANT TO LIVE THERE

2 MOVING AWAY

2 NOT IN MY BACKYARD

2 NOT IN MY STATE

2 NOT LIVE NEAR

2 NOT LIVE THERE

2 NOT NEAR ME

2 NOT WANTING TO LIVE THERE

2 SHOOT INTO SPACE

2 WOULDN'T LIVE THERE

1 ANOTHER STATE

1 ARIZONA A GOOD CHOICE

1 DIDNT WANT TO LIVE NEAR IT

1 DO NOT DEPOSIT IN ALABAMA

1 DONT BRING IT HERE

1 DONT LIVE AROUND THAT AREA

1 DON'T LIVE BY IT

1 DON'T LIVE CLOSE TO IT

1 I DONT LIVE THERE

1 DON'T PUT IT HERE

1 DONT WANT IT AROUND HERE

1 DONT WANT TT IN MY NEIGHBORHOOD

1 DONT WANT IT NEAR HOUSE

1 DONT WANT TO BE AROUND

1 DONT WANT TO BE AROUND ONE

1 DONT WANT TO BE NEAR ONE

1 DONT WANT TO BE THERE

1 DONT WANT TO LIVE IN NEIGHBORHOOD
1 DONT WANT TO BE THERE

1 FLIGHT OF PEOPLE AWAY

1 GET AWAY

1 GET AWAY FROM HERE

1 GET FAR AWAY

1 GET IT AWAY FROM US

1 GET IT OUT OF THE EARTH

1 GIVE IT TO RUSSIANS

1 GLAD IT'S NOT NEAR US

1 HOPE WE NEVER HAVE ONE AROUND HERE

1 I DONT WANT IN MY NEIGHBORHOOD

1 I DONT WANT THEM NEAR ME

1 I DON'T WANT TO BE AROUND IT

1 I HOPE IT'S NOT NEXT DOOR

1 I WANT IT FAR AWAY FROM LONG BEACH

1 I WOULD MOVE

1 I WOULDNT WANT IT IN MY BACKYARD

1 I WOULDNT WANT TO BE AROUND IT

1 I WOULDNT WANT TO BE NEAR IT

1 I WOULDNT WANT TO BE THERE

1 I WOULDNT WANT TO LIVE NEAR ONE

1 IN A DIFFERENT STATE THEN WHERE I LIVE

1 IT SHOULD BE IN OUTER SPACE

1 KEEP AWAY

1 KEEP IT AWAY

1 KEEP IT AWAY FROM ME

1 KEEP IT OUT OF MY YARD

1 KEEP IT OUT THERE

1 KEEP OUT OF THIS COUNTRY

1 LONG WAYS FROM FLORIDA

1 MOVE AWAY

1 NO DESIRE TO BE CLOSE

1 NOT A GOOD PLACE TO LJVE

1 NOT AROUND HERE

1 NOT AROUND HERE!

1 NOT BE NEAR IT

1 NOT BE THERE

1 NOT CLOSE TO ME

1 NOT GO THERE

1 NOT HERE, I HOPE

1 NOT IN CALIFORNLA

1 NOT IN KENTUCKY

1 NOT IN MY NEIGHBORHOOD

1 NOT IN UNITED STATES

1 NOT LIVE BY

1 NOT LIVE NEAR $\mathrm{TT}$

1 NOT LIVING THERE

1 NOT NEAR

1 NOT NEAR MY HOUSE

1 NOT NEXT TO ME

1 NOT ON THIS PLANET

1 NOT SPEND TIME THERE

1 NOT TO GO NEAR

1 NOT UNDER ME

1 NOT WANT IT IN PHOENIX

1 NOT WANTING TO BE AROUND THEM

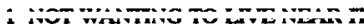

1 NOT WHERE I LIVE

1 PEOPLE ARE MOVING AWAY

1 PLACE I DONT WANT TO BE

1 PLACE I WOULD NOT WANT TO BE

1 PUT IT EAST OF THE ROCKIES

1 PUT IT IN TEXAS

1 PUT IT IN THAILAND

1 PUT IT ON ANOTHER PLANET

1 PUT IT SOMEWHERE EISE

1 PUT ON MOON

1 REASON WE LEFT ARIZONA

1 RELOCATION

1 SEND IT TO ANOTHER PLANET

1 SEND IT TO CALIFORNIA

1 SEND IT TO OUTER SPACE

1 SEND TO RUSSIA OR CUBA

1 SENT TO MOON

1 SHIP TO RUSSIA

1 SHOT OFF IN SPACE

1 SHOULD BE A LONG WAY AWAY

1 SHOULD BE IN SIBERIA

1 SHOULDNT BE HERE

1 SOME OTHER STATE

1 SOME PLACE FAR AWAY

1 SOMEONE ELSES STATE

1 SOMETHING I DONT WANT NEAR ME

1 SOMETHING I WOULD AVOID

1 SOMETHING I WOULDNT WANT TO BE AROUND.

1 SOMEWHERE AWAY FROM ME

1 STORE IT IN NEW MEXICO

1 STORED SOMEPLACE ELSE

1 TO GET FAR AWAY FROM IT AS POSSIBLE

1 TO THE MOON

1 WANT IT TO BE SOMEPLACE ELSE

1 WANT TO BE FAR FROM IT

1 WANT TO STAY AWAY FROM IT

1 WOULD NOT UIVE NEAR IT

1 WOULD NOT WANT TO LIVE NEAR

1 WOULDNT BE NEAR IT

1 WOULDNT LIKE TO HAVE IT IN MY BACKYARD

1 WOULDNT WANT IN YOUR NEIGHBORHOOD

1 WOULDNT WANT IT AROUND

1 WOULDNT WANT IT BY ME

1 WOULDNT WANT IT HERE

1 WOULDNT WANT IT IN OUR STATE

1 WOULDNT WANT IT NEXT DOOR

1 WOULDNT WANT IT NEXT TO ME

1 WOULDN'T WANT IT WHERE I LIVE

1 WOULDNT WANT ONE NEAR ME

1 WOULDNT WANT TO BE AROUND IT

1 WOULDNT WANT TO BE CLOSE

1 WOULDNT WANT TO BE CLOSE TO ONE

1 WOULDNT WANT TO LIVE BY ONE

1 WOULDNT WANT TO LIVE CLOSE

1 WOULDNT WANT TO LIVE NEAR THERE

1 WOULDNT WANT TO LIVE NEARBY

TOTAL Frequency for Category: 273 (2.73\%) 


\section{NEGATIVE}

e. War / Annihilation

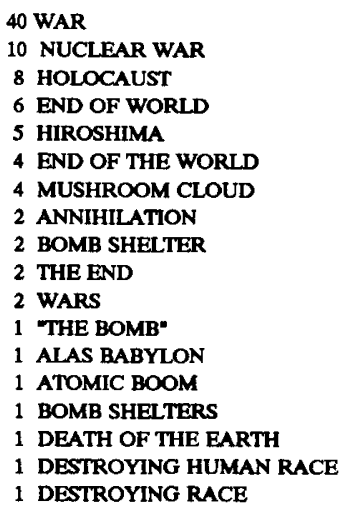

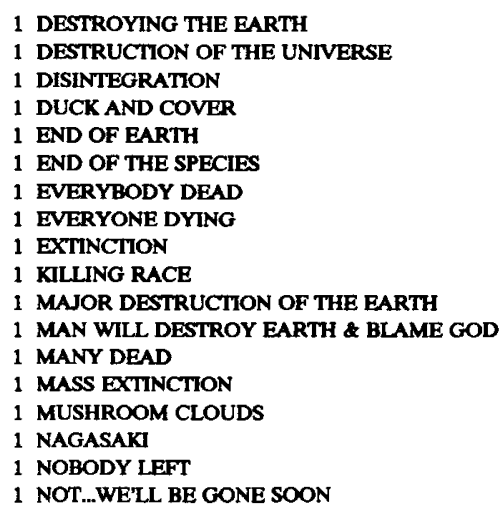

1 NUCLEAR ATTACK

1 NUCLEAR ATTACKS

1 PLANETARY DESTRUCTION

1 POSSIBLE DEVASTATION OF THE POPULATION

1 PRIME TARGET

1 THE END OF THE WORLD

1 TOTAL DEVASTATION

1 TOTAL DISASTER

1 ULTIMATE DOOM

1 WAR!

1 WERE GOING TO DIE

1 WHOLE STATES DISINTEGRATING

1 WILL KILL OUR PLANET

1 WORLD DESTRUCTION

1 WORLD GONE IN A COUPLE OF DECADES

1 WORLD WAR III

TOTAL Frequency for Category: 126 (1.26\%)

\section{f. Societally Unpopular}

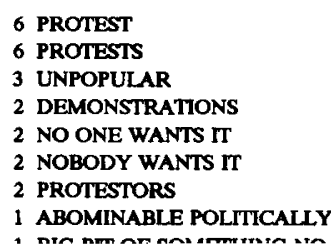

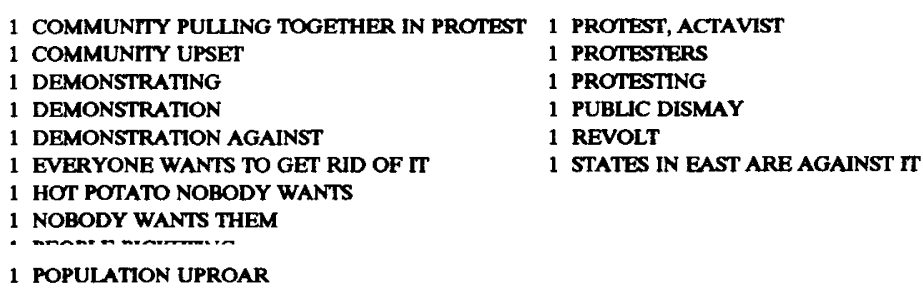

TOTAL Frequency for Category: $41(0.41 \%)$

\section{g. Crime and Corruption}

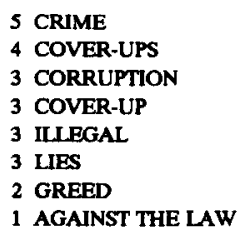

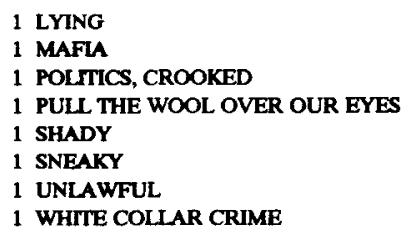

$\begin{array}{ll}1 & \text { BRIBERY } \\ 1 & \text { CORRUPT } \\ 1 & \text { CRIME INCREASE } \\ 1 & \text { DECEIT } \\ 1 & \text { GOVERNMENT COVER UP } \\ 1 & \text { GOVERNMENT FRAUD } \\ 1 & \text { GREEDY } \\ 1 & \text { LARCENY }\end{array}$

TOTAL Frequency for Category: $40(0.40 \%)$

h. Decay / Slime / Smell

$$
\begin{array}{ll}
9 & \text { SMELL } \\
6 & \text { DECAY } \\
4 & \text { SLIME } \\
4 & \text { SMELLY } \\
3 & \text { SLUDGE }
\end{array}
$$

SLUDGB

$Y$

(1)




\section{NEGATIVE}

j. Negative Toward Decision Makers and Process

$\begin{array}{lll}5 \text { MISMANAGEMENT } & 1 \text { IRRESPONSIBILITY OF GOVERNMENT/BUSINESS } 1 \text { SHOULD HAVE BEEN DEALT WTTH BEFORE } \\ 2 \text { NEGLGENCE } & 1 \text { IRRESPONSIBLE } & 1 \text { SHOULD HAVE BEEN DONE IN 70'S } \\ 1 \text { CANT TRUST PEOPLE } & 1 \text { IRRESPONSIBLE PEOPLE } & 1 \text { SHOULD HAVE THOUGHT ABOUT THAT IN 1945 } \\ 1 \text { CONCERNED ABOUT LONG TERM GOALS } & 1 \text { KEEP US MORE INFORMED } & 1 \text { THEY DONT CARE WHO GETS SICK FROM TT } \\ 1 \text { GOVERNMENT IS NOT FACING UP TO ERRORS } & 1 \text { LACK OF CONSIDERATION } & 1 \text { THEY DONT CARE WHO THEY KILI } \\ 1 \text { GOVERNMENT ISNT DOING ANYTHING } & 1 \text { LACK OF CONSIDERATION FOR FUTURE } & 1 \text { THEY NEED TO UPDATE } \\ 1 \text { GOVERNMENT NOT LEARNING FROM MISTAKES } & 1 \text { MISTRUST } & 1 \text { UNTRUSTING } \\ 1 \text { I DONT TRUST THEM } & 1 \text { NATIONS TRYING TO PICK UP PIECES } & 1 \text { UNTRUSTWORTHY } \\ 1 \text { IRRESPONSIBILITY } & 1 \text { SHORTSIGHTEDNESS } & 1 \text { WORRY ABOUT MANAGEMENT }\end{array}$

TOTAL Frequency for Category: $32(0.32 \%)$

k. Commands to Not Build or to Eliminate Them

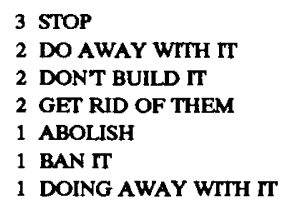

1 DONT

1 DONT DO IT

1 GET RID OF

1 GET THEM OUT OF HERE

1 PUT OUT OF BUSINESS

1 QUIT IT

1 OUIT MAKING USE OF IT

\author{
1 RID OF IT \\ 1 SHOULD BE CLOSED DOWN \\ 1 SHUT IT DOWN \\ 1 STOP IT \\ 1 STOP THOSE REPOSTTORIES
}

TOTAL Frequency for Category: 24 (0.24\%)

Wrong or Bad Solution

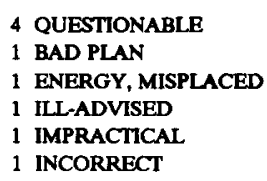

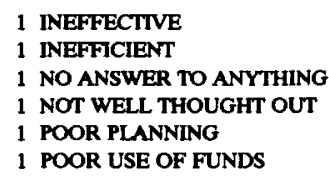

1 QUESTIONABLE SOLUTION FOR PROBLEM

1 UNRELIABLE

1 WONT WORK

1 WRONG ALLEY

\section{TOTAL Frequency for Category: 19 (0.19\%)}

m. No Nuclear, Stop Producing

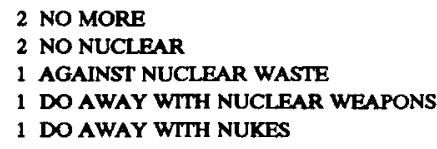

TOTAL Frequency for Category: 15 (0.15\%)

n. Unjust

3 INHUMANE
3 UNFAIR
1 CRIME AGAINST SOCIETY
1 CRUELTY

1 EXPLOTTATION

1 EXPLOITATIONS

1 IT OUGHT TO BE AGAINST THE LAW

\author{
1 NO RIGHT \\ 1 SHOULD BE AGAINST LAW
}

TOTAL Frequency for Category: 14 (0.14\%)

o. Violence

2 MURDER

2 TERRORISTS

1 MASS MURDER

1 TERRORISM

TOTAL Frequency for Category: $10(0.10 \%)$ 


\section{NEGATIVE}

p. Prohibited

2 PROHIBITED

1 FORBIDDEN

1 NOT ALLOWED

1 WE'RE NOT SUPPOSED TO HAVE TT

TOTAL Frequency for Category: $5(0.05 \%)$

q. Negative - Other

1 AGAINST NATURE

1 DEAD MEAT

1 DEADLY FORCE

1 DEATH THOUGHTS IN SOCIETY

1 FEAR PEOPLE

$\begin{array}{ll}1 & \text { FIRE \& BRIMSTONE } \\ 1 & \text { FORBIDDING } \\ 1 & \text { HORRIBLE FOR ONE PLACE } \\ 1 & \text { I DONT LIKE THINGS I DONT KNOW ABOUT } \\ 1 & \text { INCONVENIENT }\end{array}$

1 MESS UP THINGS

1 NEVER PUT IN THE RIGHT PLACE

1 NOT AT ALL.

1 POOR USE OF ENVIRONMENT

1 TERRIBLE FOR PEOPLE WHO LIVE NEARBY

TOTAL Frequency for Category: $15(0.15 \%)$ 


\section{LOCATIONS}

\section{a. Non-Nevada Locations}

$\begin{array}{ll}36 & \text { NEW MEXICO } \\ 31 & \text { ARIZONA } \\ 16 & \text { PALO VERDE } \\ 15 & \text { UTAH } \\ 11 & \text { DENVER } \\ 10 & \text { CALIFORNIA } \\ 8 & \text { COLORADO } \\ 7 & \text { RUSSIA } \\ 5 & \text { PHOENIX } \\ 4 & \text { HANFORD, WASHINGTON } \\ 4 & \text { TEXAS } \\ 3 & \text { ALBUQUERQUE } \\ 3 & \text { HANFORD } \\ 3 & \text { WASHINGTON } \\ 3 & \text { WASHINGTON STATE } \\ 3 & \text { WHITE SANDS } \\ 3 & \text { WYOMING } \\ 2 & \text { CANADA } \\ 2 & \text { KANSAS } \\ 2 & \text { LOS ALAMOS } \\ 2 & \text { MIDWEST } \\ 2 & \text { NEW YORK } \\ 2 & \text { PENNSYLVANIA } \\ 2 & \text { SOUTH CAROLINA } \\ 2 & \text { TUCSON } \\ 2 & \text { WASHINGTON, D.C. } \\ 1 & \text { ALABAMA } \\ 1 & \text { ALASKA } \\ 1 & \text { ALBUQUERQUE AIR FORCE BASE } \\ 1 & \text { AMERICA } \\ \end{array}$
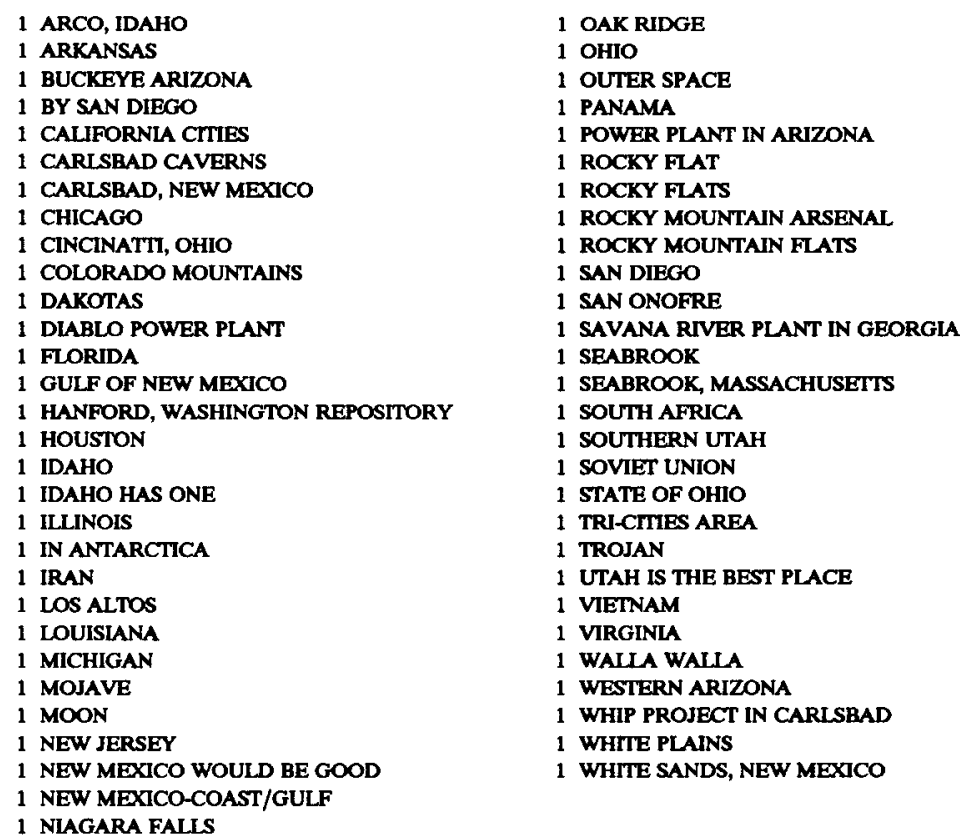

TOTAL Frequency for Category: 245 (2.45\%)

\section{b. Storage Location / Containers}

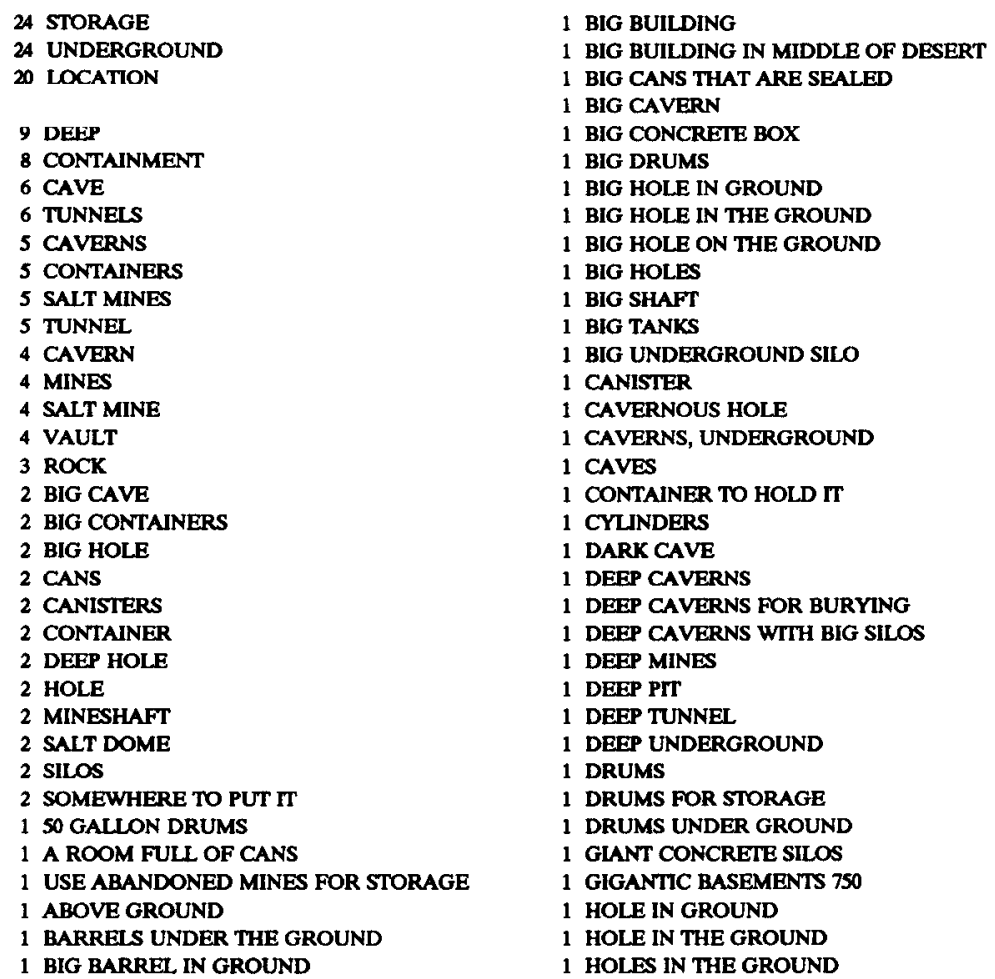

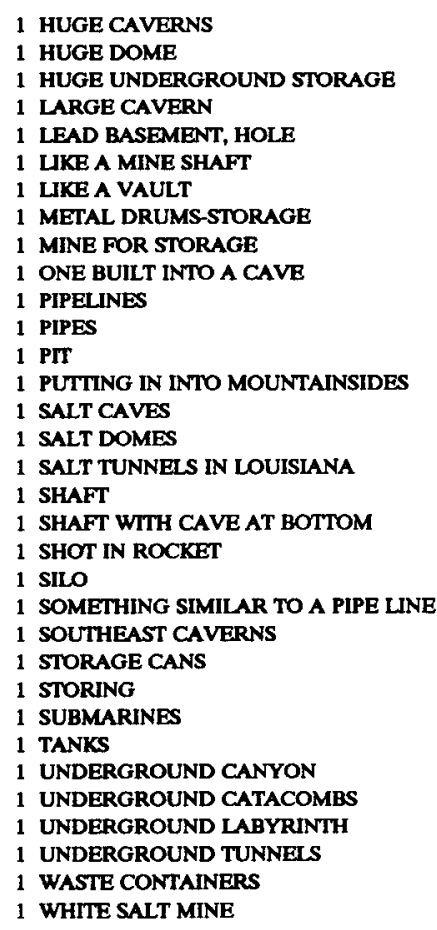

TOTAL Frequency for Category: 243 (2.43\%) 


\section{LOCATION}

\section{c. Desert / Barren}

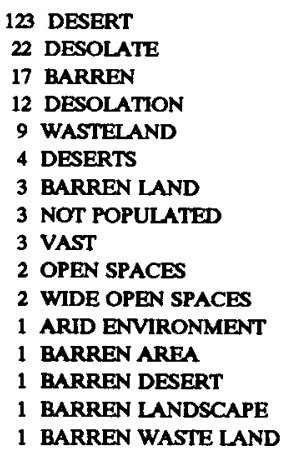

\author{
1 BARREN ZONE \\ 1 DESERT AREA \\ 1 DESERT AREA PREFERABLY \\ 1 DESERT STATES \\ 1 DESOLATE LAND \\ 1 EMPTY AREA \\ 1 EMPTY PLACE \\ 1 FLAT OPEN AREA \\ 1 I HOPE IT'S IN THE DESERT \\ 1 IN DESERT \\ 1 IN THE DESERT \\ 1 LARGE AREA \\ 1 LARGE OPEN SPACE \\ 1 LARGE OPEN SPACES \\ 1 LIKE A DESERT, NOTHING THERE

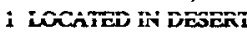

1 OPEN

1 OPEN LAND

1 OPEN SPACE

1 PRETTY BARREN

1 SAND, DESERT, BARENESS

1 SOMEPLACE OUT IN THE DESERT

1 SOMEWHERE IN DESERT

1 SPARSE

1 THE DESERT

1 VACANT LAND

1 VAST DESERT

1 VAST LAND

1 WASTELAND PLACE

1 WASTELANDS

1 WIDE OPEN

i WiDE OFEN STACE

TOTAL Frequency for Category: 237 (2.37\%)

\section{d. Nevada / Las Vegas}

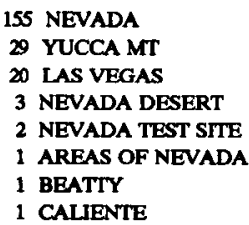

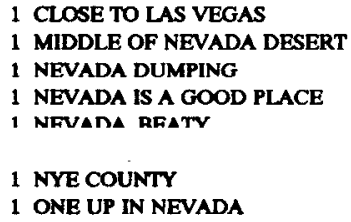

\author{
1 POOR, POOR NEVADA \\ 1 PUT IT IN THE DESERT IN NEVADA \\ 1 PUT ONE UNDER LAS VEGAS \\ 1 THE STATE OF NEVADA \\ 1 VRSAS
}

1 YUCCA, TONOPAH

TOTAL Frequency for Category: 227 (2.27\%)

\section{e. Waste / Garbage / Dumps}

80 WASTE
27 NUCLEAR WASTE
25 GARBAGE
18 DUMP
8 TRASH
5 RADIOACTIVE WASTE
3 DUMPING
3 DUMP SITE
3 GARBAGE DUMP
3 HAZARDOUS WASTE
3 WASTES
2 ATOMIC WASTE
2 DUMP SITES
2 DUMPING GROUND

\begin{tabular}{|c|c|}
\hline 2 DUMPS & 1 SEWAGE SYSTEM \\
\hline 2 LANDFILL & 1 SEWERS \\
\hline 2 SEWAGE & 1 TOXIC DUMP \\
\hline 2 SEWER & 1 TRASH CAN IN GROUND \\
\hline 2 WASTE PRODUCTS & 1 UNDERGROUND DUMPING \\
\hline 1 A DUMP & 1 UNDERGROUND FULL OF TRASH \\
\hline 1 DUMP SITE, OVERGROWN & 1 UNDERGROUND GARBAGE CAN \\
\hline 1 ILLEGAL DUMPING GROUNDS & 1 UNDERGROUND SEWAGE REPOSITORY \\
\hline $\begin{array}{l}1 \text { LAND DUMPSTER } \\
1 \text { I ANRETI I C InD rADRASER }\end{array}$ & $\begin{array}{l}1 \text { UNDERGROUND STORAGE } \\
1 \text { WA CTR PFT }\end{array}$ \\
\hline $\begin{array}{ll}1 \text { LOTS OF GARBAGE } \\
1 \text { MORE GARBAGE }\end{array}$ & 1 WASIE, UNDERGKOUND \\
\hline
\end{tabular}

2 DUMPS

2 SEWAGE

STE PRODUCTS

1 DUMP STTE OVERGROWN

1 ILLEGAL DUMPING GROUNDS

LAND DUMPSTER

LOTS OF GARBACE

1 NUCLEAR WASTE DUMPS IN UNITED STATES 


\section{LOCATION}

\section{f. Isolated}

$\begin{array}{ll}13 & \text { ISOLATED } \\ 8 & \text { ISOLATION } \\ 5 & \text { AWAY FROM PEOPLE } \\ 5 & \text { DESERTED } \\ 5 & \text { REMOTE } \\ 5 & \text { UNPOPULATED } \\ 4 & \text { HIDDEN } \\ 4 & \text { SECLUDED } \\ 3 & \text { DESOLATE AREA } \\ 3 & \text { DISTANT } \\ 2 & \text { NOT POPULATED AREA } \\ 2 & \text { REMOTE AREA } \\ 2 & \text { UNINHABITED } \\ 1 & \text { A PLACE THAT IS NOT CLOSE TO HABITATION } \\ 1 & \text { ABANDONED AREA } \\ 1 & \text { AREA WHERE THERE ARE FEW PEOPLE } \\ 1 & \text { AS FAR AWAY FROM CIVILIZATION } \\ 1 & \text { AWAY FROM } \\ 1 & \text { AWAY FROM CITIES } \\ 1 & \text { AWAY FROM EVERYTHING }\end{array}$
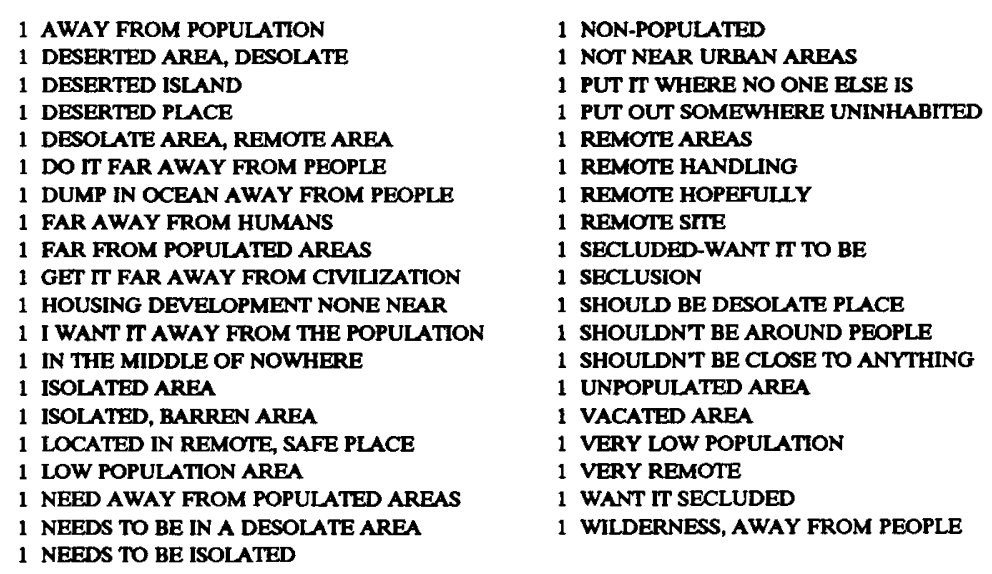

TOTAL Frequency for Category: 107 (1.07\%)

\section{g. Facilities and Their Construction}

$\begin{aligned} 12 & \text { CONCRETE } \\ 11 & \text { DIRT } \\ 5 & \text { BIG } \\ 4 & \text { LARGE } \\ 2 & \text { BUILDING } \\ 2 & \text { BUILDINGS } \\ 2 & \text { CEMENT } \\ 2 & \text { STEEL } \\ 2 & \text { STORAGE FACILITY } \\ 1 & \text { BIG TRAP DOORS } \\ 1 & \text { CRANES LOWERING }\end{aligned}$

\author{
1 ELEVATORS \\ 1 FACILTIES \\ 1 FACILITY \\ 1 FOUNDATION \\ 1 GIGANTIC \\ 1 GLASS \\ 1 GRANITE \\ 1 HEAVY CEMENT \\ 1 LARGE METALLIC \\ 1 LEAD SHIELDING \\ 1 LEAD WALLS
}

\author{
1 LOTS OF CONCRETE \\ 1 MASSIVE \\ 1 METAL \\ 1 PUTTING UP A SITE \\ 1 ROCK STRUCTURE \\ 1 SOLID ROCK \\ 1 STEEL DOORS \\ 1 STEEI, WALLS \\ 1 STEEL WALLS UNDERGROUND \\ 1 STRUCTURE \\ 1 TUNNELING THRU A MOUNTAIN IN NEVADA
}

TOTAL Frequency for Category: $66(0.66 \%)$

\section{h. Bury It}

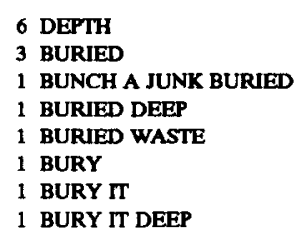

\section{i. Locations - Other}

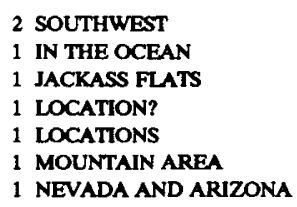

$\begin{array}{ll}1 & \text { BURY UNDERGROUND } \\ 1 & \text { BURY WASTES } \\ 1 & \text { BURYING WASTE } \\ 1 & \text { DIG A HOLE } \\ 1 & \text { DIG DEEPER } \\ 1 & \text { NIN } \\ 1 & \text { LUUIN } \\ 1 & 1 \text { HOPE IT'S DEEP }\end{array}$

1 IT BETTER BE DEEP 1 NOT DEEP ENOUGH

TOTAL Frequency for Category: $30(0.30 \%)$

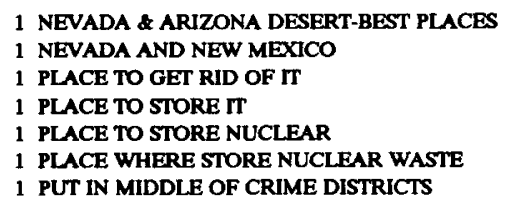

\author{
1 PUT WHERE NO PROBLEMS \\ 1 SANDID MOUNTAINS \\ 1 UNDERGROUND GARAGE \\ 1 UNDERGROUND SHELTER \\ 1 WOULDNT WANT PEOPLE TO KNOW WHERE
}

TOTAL Frequency for Category: $20(0.20 \%)$ 


\section{RADIATION, PHYSICAL STATES}

a. Radiation / Nuclear

197 RADIATION
35 RADIOACTIVTT
23 RADIOACTIVE
16 NUCLEAR
5 PLUTONIUM
4 GLOW IN THE DARK
3 GLOWING
3 HALF LIFE
3 REACTORS
3 URANIUM
2 HALF-LIFE
2 RADIOACTIVITY
2 RADIOACTTVE MATERIAL
1 ATOMIC
1 BETA RAYS
1 DEGREE OF RADIATION
1 FISSION

$\begin{array}{ll}1 & \text { GLOW } \\ 1 & \text { GLOW IN DARK } \\ 1 & \text { GLOWING EARTH } \\ 1 & \text { GLOWING POPULATION } \\ 1 & \text { HAZARD OF RADIATION } \\ 1 & \text { I PICTURE THE TALL REACTORS } \\ 1 & \text { MEN WTTH FUNNY RADIATION SUITS ON } \\ 1 & \text { MUSHROOM BOMB } \\ 1 & \text { NUCLEAR CONTAMINATES } \\ 1 & \text { NUCLEAR DUMP } \\ 1 & \text { NUCLEAR MELTDOWN } \\ 1 & \text { NUCLEAR PRODUCTS } \\ 1 & \text { NUCLEAR RADIATION } \\ 1 & \text { NUCLEAR RESEARCH } \\ 1 & \text { NUCLEAR SIGHTS } \\ 1 & \text { NUCLEAR STORAGE } \\ 1 & \text { NUCLEAR TREE }\end{array}$

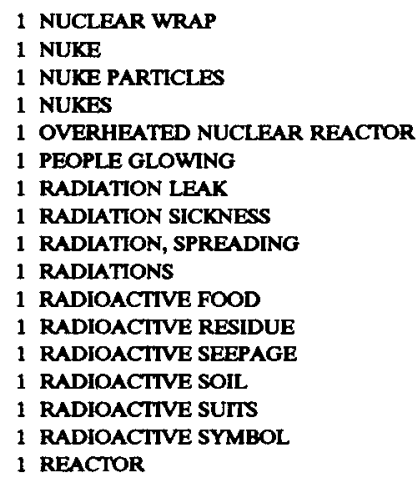

TOTAL Frequency for Category: 336 (3.36\%)

b. Chemicals \& Physical States (Liquids, Gases)
19 CHEMICAIS
6 VOLATILE
5 FUMES
4 GAS
3 MERCURY
2 RADON GAS
1 ACID
1 ACIDS

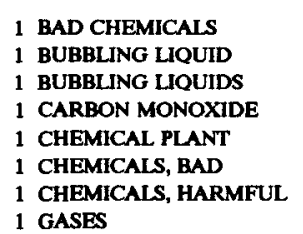

1 LIQUID

1 METHANE GAS

1 POISONOUS GASES

1 STORED CHEMICALS

1 VAPORS

1 VOLATILE

TOTAL Frequency for Category: 55 (0.55\%)

\section{c. Fire / Hot}

$$
\begin{array}{ll}
10 & \text { HEAT } \\
9 & \text { FIRE } \\
3 & \text { BURNS } \\
3 & \text { HOT }
\end{array}
$$

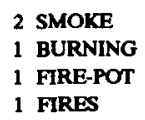

TOTAL Frequency for Category: $33(0.33 \%)$ 


\title{
V. SAFETY, SECURITY
}

a. Safe and Secure

$\begin{array}{ll}100 & \text { SAFETY } \\ 37 & \text { SAFE } \\ 17 & \text { SECURTY } \\ 5 & \text { PROTECTION } \\ 3 & \text { SAFEGUARDED } \\ 2 & \text { GEOLOGICALIY SAFE } \\ 2 & \text { HIGH SECURITY } \\ 2 & \text { IS TT SAFE } \\ 2 & \text { SAFER } \\ 2 & \text { SECURE } \\ 1 & \text { AS LONG AS ITS SAFE WE WOULD BE SAFE } \\ 1 & \text { AWAY FROM EARTHQUAKES } \\ 1 & \text { BETTER BE SAFE } \\ 1 & \text { CONCERN ABOUT SAFETY } \\ 1 & \text { CONCERN FOR SAFETY } \\ 1 & \text { ENVIRONMENTAL SAFETY } \\ 1 & \text { FAIRLY SAFE } \\ 1 & \text { FINDING A SOLUTION TO MAKE SAFE } \\ 1 & \text { HIGHLY ENGINEERED, SECURE PLACE } \\ 1 & \text { HIGHLY SECURE } \\ 1 & \text { HOW SAFE } \\ 1 & \text { HOW SAFE IT IS }\end{array}$
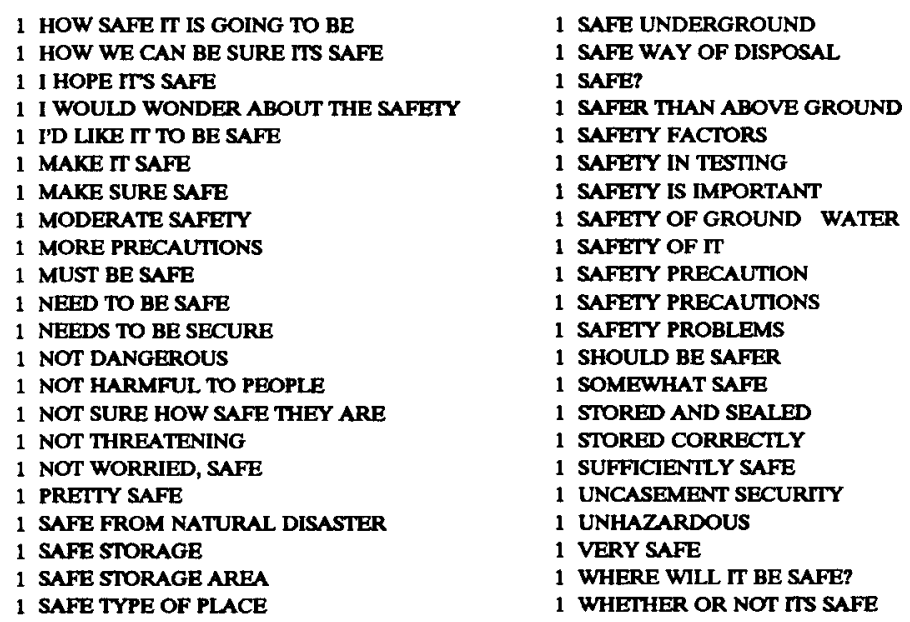

TOTAL Frequency for Category: 228 (2.28\%)

\section{b. Facilities Security}

$\begin{array}{ll}6 & \text { SECRET } \\ 4 & \text { SECRETIVE } \\ 3 & \text { FENCES } \\ 3 & \text { GUARDED } \\ 2 & \text { GUARDS } \\ 2 & \text { PROTECTED } \\ 2 & \text { SECRETS } \\ 2 & \text { TOP SECRET } \\ 1 & \text { A FENCED IN AREA } \\ 1 & \text { BADGES }\end{array}$

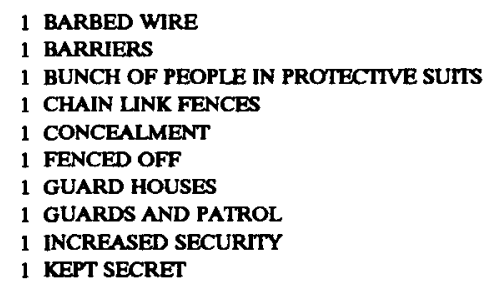

\author{
1 MEN IN FIREPROOF OUTFTTS \\ 1 OFF LIMITS \\ 1 OFF LMITS ZONE \\ 1 POTENTIAL SECURTY \\ 1 SECRET TUNNEIS \\ 1 SECURITY GUARD \\ 1 SECURTYY STATIONS \\ 1 VERY TIGHT SECURITY
}

TOTAL Frequency for Category: 44 (0.44\%)

c. Control, Containment and Cleanup
3 CONTROLLED
2 CLEAN UP
2 CONTAIN
2 CONTAINED
1 CLEAN IT UP
1 CLEAN-UP

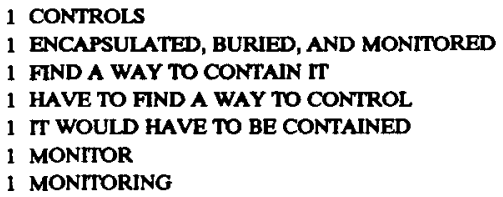

1 CONTROLS

1 ENCAPSULATED, BURIED, AND MONITORED

1 FIND A WAY TO CONTAN IT

1 HAVE TO FIND A WAY TO CONTROL

1 IT WOULD HAVE TO BE CONTAINED

1 MONITOR

MONIIORING

\author{
1 MUST BE CONTAINED \\ 1 NEED TO BE MONITORED \\ 1 NEEDED TO MONITOR \\ 1 NEEDS BETTER CONTROL \\ 1 NEEDS CONTROL \\ 1 NEEDS TO BE CLEANED UP/REMOVED \\ 1 SEALED FOREVER
}

TOTAL Frequency for Category: 32 (0.32\%)

d. Caution

13 CAUTION

7 CAREFUL

$$
\begin{aligned}
& 4 \text { CAUTIOUS } \\
& 1 \text { BE CAREFUL }
\end{aligned}
$$

TOTAL Frequency for Category: 27 (0.27\%) 


\section{CONCERNS}

\section{a. Problems}

$\begin{array}{ll}26 & \text { PROBLEMS } \\ 22 & \text { TROUBLE } \\ 12 & \text { PROBLEM } \\ 6 & \text { CHAOS } \\ 4 & \text { BIG PROBLEM } \\ 3 & \text { QUESTIONS } \\ 2 & \text { SCANDAL } \\ 2 & \text { TROUBLESOME } \\ 1 & \text { A LOT OF PROBLEMS } \\ 1 & \text { BIG CLEAN-UP PROBLEM } \\ 1 & \text { BIG TROUBLE } \\ 1 & \text { BOTHERSOME } \\ 1 & \text { CAUSE SOME HARDSHIP TO PUBLIC } \\ 1 & \text { COMPLICATED } \\ 1 & \text { CONCERN ABOUT HAZARD } \\ 1 & \text { CONCERN FOR ENVIRONMENT } \\ 1 & \text { DEEP TROUBLE }\end{array}$

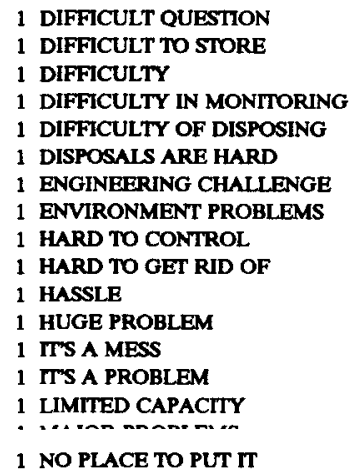

1 PICKETING

1 POTENTIAL PROBLEM

1 PROBLEM FOR FUTURE GENERATIONS

1 PROBLEM TO STORE

1 PROBLEMATICAL

1 PROBLEMS FOR FUTURE GENERATIONS

1 PROBLEMS IN THE AREA

1 QUESTION

1 SCIENTIFIC PROBLEM

1 SERIOUS PROBLEM

1 TERRIBLE PROBLEM

1 THE PROBLEM OF WHERE

1 TROUBLES

1 UPSET PEOPLE

1 WHAT PROBLEMS WILL IT CAUSE

TOTAL Frequency for Category: 119 (1.19\%)

\section{b. Questions}

$\begin{array}{ll}4 & \text { WHY } \\ 3 & \text { IS IT NECESSARY } \\ 3 & \text { WHERE } \\ 1 & \text { DO WE NEED IT } \\ 1 & \text { ENVIRONMENTAL QUESTIONS } \\ 1 & \text { HOW BIG } \\ 1 & \text { HOW CAN YOU GET RID OF NUCLEAR WASTE? } \\ 1 & \text { HOW DEEP TO BURY IT } \\ 1 & \text { HOW EFFECT LAND } \\ 1 & \text { HOW IT AFFECTS US } \\ 1 & \text { HOW IT IS AFFECTING PLANET } \\ 1 & \text { HOW IT WILL AFFECT PEOPLE } \\ 1 & \text { HOW IT WOULD AFFECT THE COMMUNITY } \\ 1 & \text { HOW } T \text { T WOULD AFFECT THE ENVIRONMENT } \\ 1 & \text { HOW LONG HAS IT BEEN THERE } \\ 1 & \text { HOW LONG IT LASTS } \\ 1 & \text { HOW LONG UNTIL IT GETS TO GROUND LEVET }\end{array}$

NUCLEAR WASTE? I IS THERE SOME WAY TO GET RID OF IT

1 HOW LONG UNTIL IT GETS TO GROUND LEVEL 1 WHERE ARE THEY PUTTING IT?

$\begin{array}{ll}1 \text { HOW MUCH } & 1 \text { WHERE ARE YOU GOING TO PUT IT } \\ 1 \text { HOW MUCH OF QUANTTY } & 1 \text { WHERE IS IT } \\ 1 \text { HOW WEL IT IF MAINTAINED } & 1 \text { WHERE IT IS } \\ 1 \text { HOW WOULD YOU GET TT AWAY FROM PEOPLE } & 1 \text { WHERE ITS GOING TO BE } \\ 1 \text { I HAVE A LOT OF QUESTIONS } & 1 \text { WHERE PUT IT } \\ 1 \text { IS TT DANGEROUS } & 1 \text { WHERE STORED? } \\ 1 \text { IS THERE SOME WAY TO GET RID OF IT } & 1 \text { WHERE THE CLOSEST ONE IS TO ME? } \\ 1 \text { WHAT DAMAGE COULD TT DO } & 1 \text { WHERE TO BURY IT } \\ 1 \text { WHAT DO YOU DO WTTH IT } & 1 \text { WHERE TO PUT IT } \\ 1 \text { WHAT FOR } & 1 \text { WHERE TO PUT THEM } \\ 1 \text { WHAT HAPPENS } & 1 \text { WHERE WILL IT BE LOCATED } \\ 1 \text { WHAT IS IT } & 1 \text { WHETHER PRIVATE OWNED OR GOVERNMENT } \\ 1 \text { WHAT IS THE PURPOSE OF IT } & 1 \text { WHO WANTS IT } \\ 1 \text { WHAT IT MIGHT DO TO THE SOIL } & 1 \text { WHY DO WE HAVE TO HAVE TT } \\ 1 \text { WHAT TO DO WTTH IT } & 1 \text { WONDER WHERE LOCATED } \\ 1 \text { WHAT WOULD HAPPEN? } & 1 \text { WONDERING WHERE IT WAS }\end{array}$

1 HOW MUCH

HOW MUCH OF OUANTITY

HOW WELL IT IF MAINTAINED

1 WHERE IT IS

1 WHERE PUT

1 WHERE STORED?

1 WHERE THE CLOSEST ONE IS TO ME?

1 WHERE WILL IT BE LOCATED

1 WHO WANTS IT

1 WONDER WHERE LOCATED

TOTAL Frequency for Category: $58(0.58 \%)$

c. Health

22 HEALTH

1 HEALTH COVERAGE

1 HEALTH OF PEOPLE IN AREA

1 HEALTH QUESTION

TOTAL Frequency for Category: $25(0.25 \%)$

\section{d. Unsolvable}

4 FUTILE

2 IMPOSSIBLE

1 BOTHERS ME WHETHER WE CAN GET RID OF IT

1 CANT BE SAFEILY DONE

1 CANT TAKE CARE OF WASTE

\author{
1 FUTILITY \\ 1 IMPOSSIBLE DREAM \\ 1 INDISPOSABLE \\ 1 NEVER GET RID OF IT \\ 1 NEVER GETS BURIED
}

\author{
1 NEVER GOES AWAY \\ 1 NO SOLUTION \\ 1 NO WAY TO CONTROL IT \\ 1 NO WAY TO GET RID OF IT \\ 1 NOT FEASIBLE
}

TOTAL Frequency for Category: $19(0.19 \%)$

\section{e. Family}

7 CHILDREN

2 MY CHILDREN

1 AFFECTING CHILDREN

1 BABIES

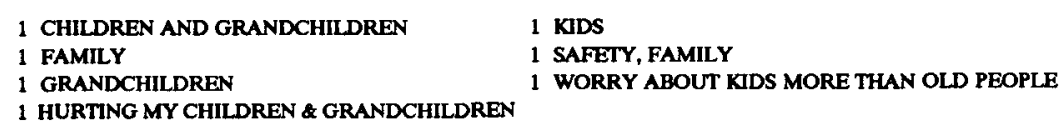

TOTAL Frequency for Category: $18(0.18 \%)$ 


\section{CONCERNS}

\section{f. Uncontrolled}

5 UNCONTROLLED

2 NO CONTROL

1 CONTROLS, LACK OF

$$
\begin{aligned}
& 1 \text { LACK OF CONTROL } \\
& 1 \text { MAY NOT BE CONTAINED }
\end{aligned}
$$

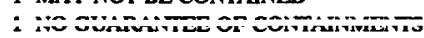

1 NOT CONTROLLED

1 UNCONTAINED

TOTAL Frequency for Category: 14 (0.14\%)

\section{g. Controversy}

3 CONTROVERSIAL

3 CONTROVERSY

2 CONFLICT

\section{h. Unpredictable}

5 UNSTABLE

2 UNPREDICTABLE

\section{A LOT OF CONTROVERSY \\ 1 ALWAYS ARGUE \\ : :ar.:}

1 SOUABBLING

1 STICKY ISSUE

TOTAL Frequency for Category: 13 (0.13\%)

i. Mistakes

2 MISTAKE

1 A FUCK UP

1 BIG MISTAKES

1 MISTAKES, MISHAPS

TOTAL Frequency for Category: $11(0.11 \%)$
1 CAREIESS
1 CARELESSNESS
1 FOLLY OF OLD MEN

1 UNFORESEEN

TOTAL Frequency for Category: $8(0.08 \%)$

1 EXTREMELY SERIOUS 1 LIFE AND DEATH

TOTAL Frequency for Category: 7 (0.07\%)
2 IMPORTANT

2 SERIOUS

k. Skeptical

2 SKEPTICAL
11 QUESTION THE NEED

1 SKEPTICAL ABOUT IT

1 SKEPTICISM

TOTAL Frequency for Category: $5(0.05 \%)$

I. Concerns - Other

2 QUESTIONING

1 CRACKS IN EARTH

1 CRITICAL TIME WISE

1 DEFECT

1 DEFECTIVE VALVES

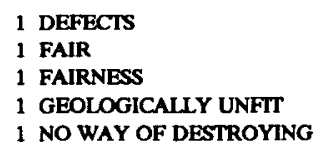

TOTAL Frequency for Category: $14(0.14 \%)$ 


\section{SOCIETAL INSTITUTIONS}

a. Government / Industry

$\begin{aligned} 58 & \text { GOVERNMENT } \\ 8 & \text { POLITICAL } \\ 5 & \text { GOVERNMENT INVOLVEMENT } \\ 4 & \text { BUREAUCRACY } \\ 3 & \text { REGULATIONS } \\ 2 & \text { BIG BUSINESS } \\ 2 & \text { BIG INDUSTRY } \\ 2 & \text { BUSINESS } \\ 2 & \text { FEDERAL GOVERNMENT } \\ 2 & \text { INDUSTRIAL } \\ 1 & \text { A LOT OF SAFETY REGULATIONS } \\ 1 & \text { CITY HALL } \\ 1 & \text { CONGRESS } \\ 1 & \text { DEALING WITH THE GOVERNMENT } \\ 1 & \text { DEFENSE DEPARTMENT } \\ 1 & \text { DEPARTMENT OF DEFENSE }\end{aligned}$

1 DOW COMPANY

1 ENVIRONMENTAL PROTECTION AGENCY

1 ENVIRONMENTAL REGULATIONS

1 FEDERAL

1 FEDERAL RESERVE

1 FEDS

1 FUCKED UP GOVERNMENT

1 GOVERNMENT CONTROL

1 GOVERNMENT CONTROLLED

1 GOVERNMENT DOLLARS IN RESEARCH

1 GOVERNMENT FORCE

1 GOVERNMENT INTERFERENCE

1 GOVERNMENT IS RESPONSIBLE

1 GOVERNMENT SPENDING 1 UNITED STATES GOVERNMENT IS FUCKED

1 GOVERNMENT, BAD

\author{
1 GOVERNMENT, US. \\ 1 GOVERNMENTS \\ 1 INDUSTRY \\ 1 LARGE CORPORATIONS NOT DOING \\ 1 LAWS \\ 1 NEGATTVE GOVERNMENT \\ 1 PEOPLE WILL PAY FOR GOVERNMENT MISTAKES \\ PRESIDENT \\ 1 PRESIDENT BUSH \\ 1 RULES AND REGULATIONS \\ 1 SENATORS \\ 1. THE GOVERNMENT
}

TOTAL Frequency for Category: 125 (1.25\%)

\section{b. Military / Weapons}

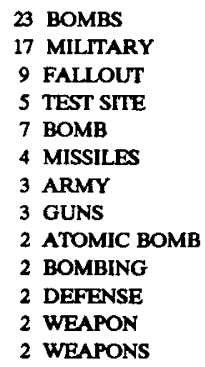

\author{
1 ARMY DEPOTS \\ 1 ATOM BOMB \\ 1 ATOMIC TESTING \\ 1 BOMBING, UNDERGROUND \\ 1 HOPE NOT NEEDED FOR WARFARE \\ 1 HYDROGEN BOMB TESTING \\ 1 LEAD TO WAR HAZARDS \\ 1 MILITARY BASE \\ 1 MILITARY DEFENSE \\ 1 MISSILE SITES \\ 1 MX MISSILE \\ 1 NATIONAL DEFENSE \\ 1 NUCLEAR BOMBS
}

\author{
1 NUCLEAR TESTING \\ 1 NUCLEAR TESTS \\ 1 NUCLEAR WARHEADS \\ 1 NUCLEAR WEAPONS \\ 1 NUKE BOMBS \\ 1 PENTAGONS \\ 1 PREPARATION OF WAR \\ 1 ROCKETS \\ 1 TESTING IN NEVADA \\ 1 WAR GAMES \\ 1 WARHEADS \\ 1 WORLD WAR II
}

TOTAL Frequency for Category: 106 (1.06\%)

c. Science, Technology, Research and Progress

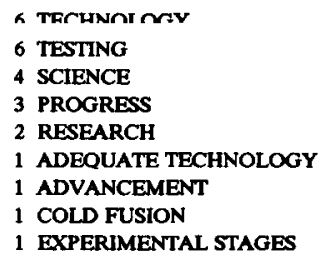

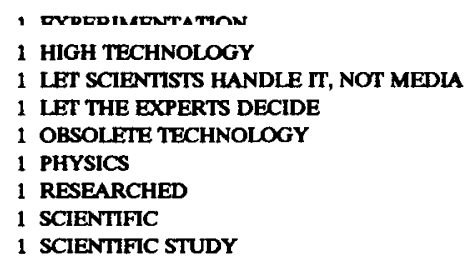

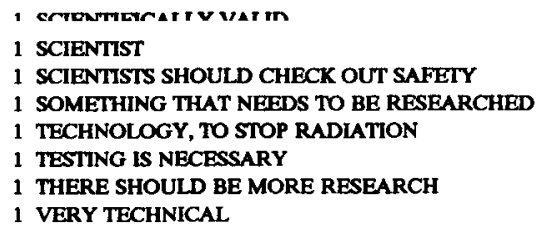

TOTAL Frequency for Category: $42(0.42 \%)$

\section{d. Political Process}

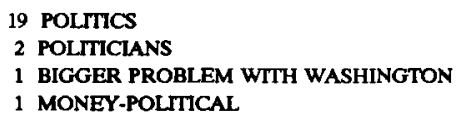

\author{
1 POLITICAL BATTLE \\ 1 POLITICAL LIES \\ 1 POLITICAL MANEUVERING \\ 1 POLITICAL PLOY
}

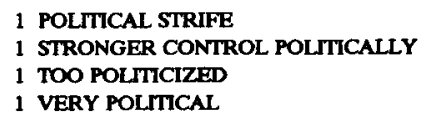

TOTAL Frequency for Category: $31(0.31 \%)$ 


\section{NECESSARY}

\section{a. Necessary}

56 NECESSARY

21 NECESSITY

17 NEEDED

9 NECESSARY EVIL

3 HAS TO BE DONE

3 WE NEED THEM

2 IT'S GOT TO GO SOMEWHERE

2 IT'S NECESSARY

2 IT'S NEEDED

1 BUT HAVE TO HAVE THEM

1 ESSENTIAL

1 GOT TO DO SOMETHING WTH IT

1 GOT TO PUT IT SOMEWHERE

1 GOT TO PUT SOMEWHERE

1 HAS TO HAPPEN

1 HAVE TO HAVE IT

1 HAVE TO HAVE THEM

\author{
1 I THINK IT'S CERTAINLY NECESSARY \\ 1 IT IS A NECESSITY \\ 1 IT IS NECESSARY \\ 1 IT MUST BE DONE \\ 1 IT'S A MUST \\ 1 ITS A SHAME THAT WE HAVE TO HAVE IT \\ 1 KNOW IT IS NECESSARY \\ 1 MANDATORY \\ 1 MUST BE SOMEWHERE \\ 1 NEED \\ 1 NEED TT \\ 1 NEED MORE \\ 1 NEEDED IN THAT AREA \\ 1 NO CHOICE \\ 1 NO OTHER CHOICE \\ 1 NOT GOOD, BUT NEEDED \\ 1 SOMETHING HAS TO BE DONE
}

\author{
1 SOMETHING THAT HAS TO HAPPEN \\ 1 SOMETHING WE HAVE TO HAVE \\ 1 SOMETHING YOU HAVE TO LIVE WITH \\ 1 SOMEWHAT NECESSARY \\ 1 THEY GOT TO DO SOMETHING WTTH IT \\ 1 THEY'RE NECESSARY \\ 1 UNDERSTAND THE NEED FOR IT \\ 1 UNPLEASANT NECESSTTY \\ 1 WE HAVE TO HAVE THEM \\ 1 WE NEED IT \\ 1 WE NEED IT AND NOBODY WANTS TT \\ 1 WE NEED MORE PLACES FOR THAT \\ 1 WE NEED ONE PLACE FOR ALL OF TT \\ 1 WE NEED SOME PLACE TO GET RID OF IT \\ 1 WE SHOULD HAVE SOME \\ 1 YOUVE GOT TO HAVE THEM
}

TOTAL Frequency for Category: $156(1.56 \%)$ 


\section{ECONOMICS}

a. Cost

23 EXPENSIVE

6 COSTLY

4 COST

4 TAXES

3 EXPENSE

2 ECONOMICS

1 BIG FUNDS

1 COST MONEY

b. Employment

33 JOBS

11 EMPLOYMENT

8 WORK

1 BUSY PLACE OF EMPLOYMENT
1 CREATED EMPLOYMENT

1 CREATED EMPLOYMENT

1 INCREASED JOBS

1 COST TO MUCH

1 COST TO TAXPAYERS

1 DIRTY PROPERTY VALUE

1 DOLLARS WASTED

1 ECONOMIC

1 EXPENSES FROM NUCLEAR WASTE

1 HIGH COST

1 HOW MUCH IT'S GOING TO COST

TOTAL Frequency for Category: $58(0.58 \%)$

TOTAL Frequency for Category: $57(0.57 \%)$

c. Money / Income

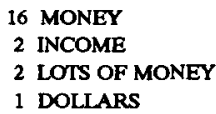

2 LOTS OF MONEY

1 DOLLARS

1 INSTANT DEBT

1 PROPERTY VALUES

1 PROPERTY VALUES TO DROP

1 THE PRICE WE PAY

1 WHATS THE COST

1 WHO'S GOING TO PAY FOR IT 


\title{
XI. INFORMATION, KNOWLEDGE
}

a. Uninformed

$\begin{array}{ll}4 & \text { DONTT KNOW } \\ 4 & \text { IGNORANCE } \\ 4 & \text { UNFAMILIAR } \\ 3 & \text { UNCERTAIN } \\ 2 & \text { CONFUSING } \\ 2 & \text { CONFUSION } \\ 2 & \text { DONT KNOW ABOUT IT } \\ 2 & \text { DONT KNOW WHAT IT IS } \\ 2 & \text { UNEDUCATED } \\ 1 & \text { DONT KNOW ENOUGH ABOUT IT TO MESS WTTH } \\ 1 & \text { DONT KNOW HOW BIG } \\ 1 & \text { DONT KNOW HOW TO DISPOSE OF IT SAFELY } \\ 1 & \text { DON'T KNOW SOLUTION } \\ 1 & \text { DONT KNOW WHAT TO DO ABOUT IT }\end{array}$

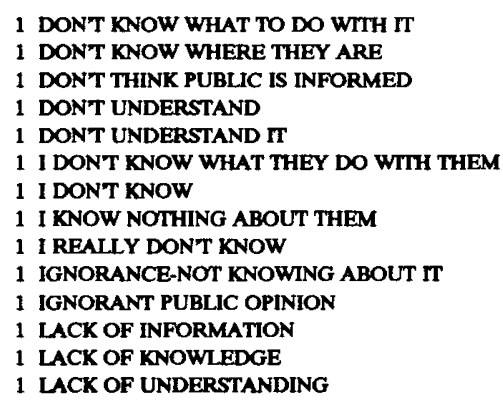

1 LACK OF WASTE DISPOSAL KNOWLEDGE

1 MISUNDERSTANDING

1 NAIVE

1 NO COMPREHENSION

1 NO IDEA

1 NOT INFORMED ABOUT IT

1 NOT SURE WHAT IT IS

1 PEOPLE DONT KNOW ENOUGH ABOUT IT

1 PUBLIC MISUNDERSTANDING

1 SO MUCH WE DONT KNOW

1 SO MUCH WE DONT UNDERSTAND

1 UNINFORMED

1 UNKNOWLEDGEABLE

TOTAL Frequency for Category: 57 (0.57\%)

b. Unsure / Unknown
20 UNKNOWN
11 UNCERTAINTY
3 UNSURE

2 DOUBT

1 UNKNOWN FACTORS OF EFFECTS

\author{
1 UNKNOWN QUALTIES
}

UNKNOWN-GOOD OR BAD?

TOTAL Frequency for Category: 39 (0.39\%)

c. Curiosity, Interest and Knowledge

$\begin{array}{ll}3 & \text { CURIOSITY } \\ 2 & \text { CURIOUS } \\ 2 & \text { EDUCATION } \\ 2 & \text { INTERESTING } \\ 2 & \text { KNOWLEDGE } \\ 1 & \text { AWARENESS }\end{array}$

1 INFORMATION

1 INFORMATIVE

1 INFORMED

1 MORE INFORMATION

1 MORE UNDERSTANDING

1 NEED TO BE EDUCATED ON IT
1 PEOPLE SHOULD BE MORE AWARE OF IT
1 PROPER EDUCATION
1 PUBLIC AWARENESS
1 PUBLIC INTEREST
1 PUBLIC KNOWLEDGE
1 UNDERSTAND

TOTAL Frequency for Category: $24(0.24 \%)$

d. Media
2 MEDIA
2 PUBLICITY
1 NEWSPAPER
1 TELEVISION
1 MEDIA CONTROL
1 RADIO
1 SENSATION PRESS

TOTAL Frequency for Category: $9(0.09 \%)$

e. Information, Knowledge - Other

1 UNSTUDIED

1 UNTESTED

TOTAL Frequency for Category: 2 (0.02\%) 


\section{POSITIVE}

\section{a. Positive, Unconcerned}

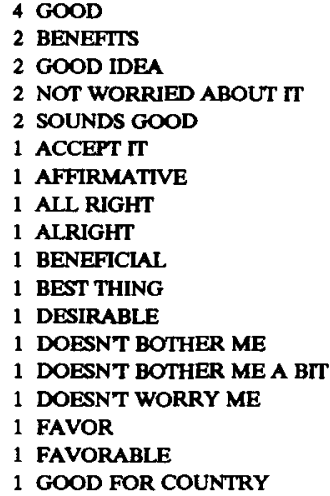

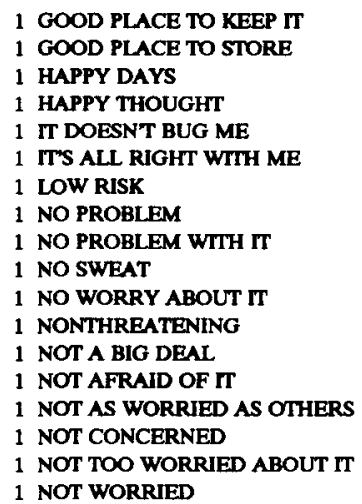

TOTAL Frequency for Category: 59 (0.59\%)

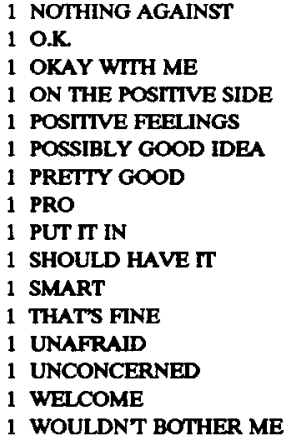

b. Effective

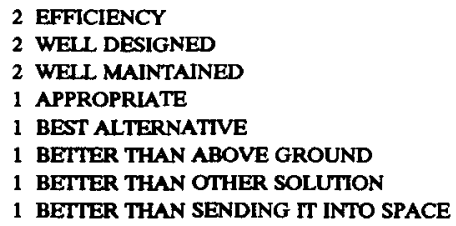

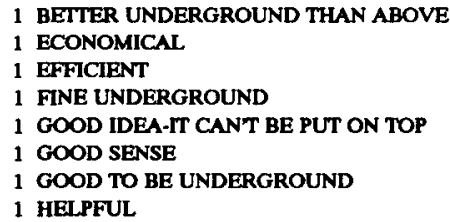

1 LOGICAL

1 MAYBE UNDERGROUND WOULD BE BEST 1 ONE OF THE BEST WAYS TO DISPOSE OF IT 1 ONE OF THE FEW SOLUTIONS WEVE GOT

1 PROPERLY DESIGNED

1 WELL SITED

TOTAL Frequency for Category: $25(0.25 \%)$

c. Improved Environment

2 CLEAN
1 ADD TO ENVIRONMENT
1 CLEAN AIR
1 CLEAN ENVIRONMENT
1 LESS POLLUTION
1 LOW SMOG

TOTAL Frequency for Category: 9 (.09\%) d. Feasible

2 FEASIBLE
1 SOLVABLE

TOTAL Frequency for Category: 3 (0.03\%)

e. Positive - Other

1 USE NUCLEAR POWER

TOTAL Frequency for Category: $1(0.01 \%)$

1 NO FALLOUT

1 NO MORE POLLUTTON 


\section{MISCELLANEOUS}

a. Future / Long Lasting

$\begin{array}{ll}14 & \text { FUTURE } \\ 8 & \text { FUTURE GENERATIONS } \\ 4 & \text { GENERATIONS } \\ 4 & \text { LONG HALF LIFE } \\ 4 & \text { PERMANENT } \\ 3 & \text { FOREVER } \\ 3 & \text { LONG TERM } \\ 2 & 10,000 \text { YEARS } \\ 2 & \text { LONG LASTING } \\ 2 & \text { LONG TERM EFFECTS } \\ 1 & \text { 25,000 YEARS } \\ 1 & \text { ALWAYS THERE } \\ 1 & \text { AWFUL LONG HALF LIFE } \\ 1 & \text { CHANCE OF FUTURE DEVELOPMENTS } \\ 1 & \text { DETRIMENTAL IN YEARS TO COME } \\ 1 & \text { DONT BIODEGRADE } \\ 1 & \text { EVERLASTING }\end{array}$

\begin{tabular}{ll}
1 & FUTURE CLEANUP \\
1 & FUTURE DANGER \\
1 & FUTURE NOT TOO BRIGHT \\
1 & FUTURE PROBLEMS WHEN ITS STILL THERE \\
1 & GENERATION \\
1 & GENERATIONS OF DAMAGE \\
1 & HALF LIFE FOREVER \\
1 & HOW LONG WLL IT LAST \\
1 & HOW LONG WILL THEY BE TRANSPORTING IT \\
1 & LASTING EFFECTS \\
1 & LASTS FOREVER \\
1 & LASTS MANY YEARS \\
1 & LONG DISSOLVING TIME \\
1 & LONG LASTING PROBLEMS \\
1 & LONG RANGE EFFECTS \\
\hline & LONG TERM TROUBLE
\end{tabular}

1 LONG-TERM PROBLEM

1 LONGEVITY

1 MAY ENDANGER FUTURE GENERATIONS

1 MORTGAGING OUR CHILDREN FUTURE

1 NO REVERSAL

1 PERMANENCE

1 PERMANENT DAMAGE

1 PROTECTION FOR FUTURE

1 STAYS IN EARTH FOREVER

1 STORAGE FOR MILLIONS OF YEARS

1 STORAGE, LONG TERM

1 THE FUTURE OF THE WORLD

1 THE NEXT GENERATION

1 UNCERTAIN FUTURE

1 YEARS DOWN ROAD

TOTAL Frequency for Category: 85 (0.85\%)

\section{b. Energy / Power}

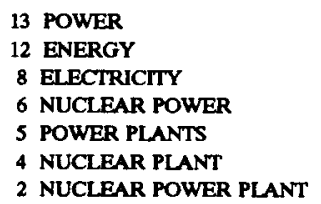

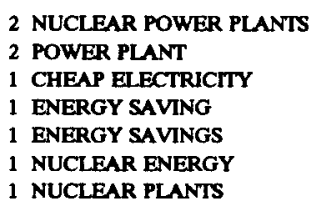

\author{
1 NUCLEAR POWER STATION \\ 1 POTENTIAL ENERGY SOURCE \\ 1 POWER STATION \\ 1 POWER, ENERGY \\ 1 UNLIMITED POWER \\ 1 USEFUL FOR ENERGY UTILIZATION
}

TOTAL Frequency for Category: $65(0.65 \%)$

\section{c. Transportation}

$\begin{array}{ll}20 & \text { TRANSPORTATION } \\ 2 & \text { CARS } \\ 2 & \text { RAILROAD } \\ 2 & \text { TRANSPORTATION, ACCIDENTS } \\ 2 & \text { TRUCKS }\end{array}$

\author{
1 HAULiNG \\ 1 RAILROAD OR TRUCK \\ 1 SHIPMENT \\ 1 SHIPMENTS \\ 1 TRAFFIC CONGESTION
}

\author{
1 TRANSPORTATION OF HAZARDOUS MATERLALS \\ 1 TRANSPORTATION, CHEMICALS \\ 1 TRANSPORTATION, RAILROAD \\ 1 TRANSPORTATION, WASTE \\ 1 TRUCK
}

TOTAL Frequency for Category: $38(0.38 \%)$

\section{d. Find Alternatives}

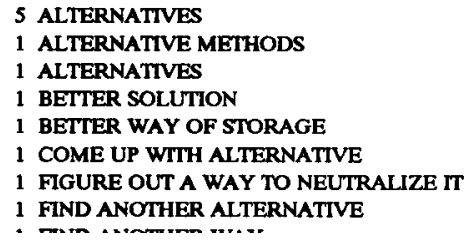

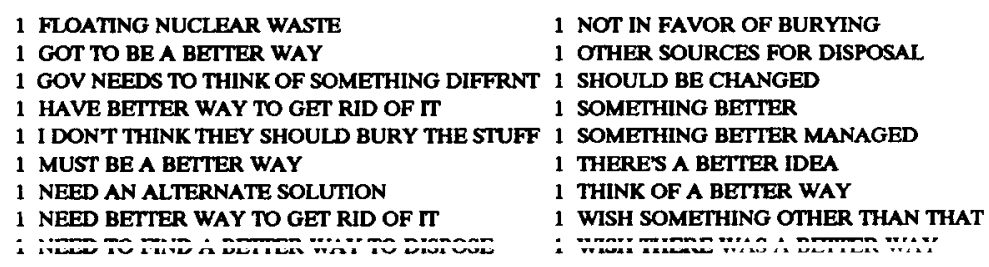

TOTAL Frequency for Category: $31(0.31 \%)$

\section{e. Natural Disasters (Potential or Actual)}

19 EARTHQUAKE

6 EARTHQUAKES

\author{
2 VOLCANO \\ 1 EARTHQUAKES, FAULTS \\ 1 FLoODS
}

TOTAL Frequency for Category: $29(0.29 \%)$ 


\section{MISCELLANEOUS}

f. Population

$$
\begin{array}{ll}
9 & \text { POPULATION } \\
5 & \text { PEOPLE } \\
3 & \text { LIVES }
\end{array}
$$

1 LARGE CTIIES

1 POPULATION INCREASE

TOTAL Frequency for Category: $22(0.22 \%)$

g. Degree of Distance

$$
\begin{array}{rl}
11 & \text { DISTANCE } \\
2 & \text { FAR } \\
1 & 100 \text { MILES AWAY } \\
1 & 20 \text {-MILES }
\end{array}
$$

1 FIFTY-MILES AWAY

1 PROXIMITY
1 CLOSE TO WHERE I LIVE
1 DISTANCE AWAY FROM THINGS
1 DISTANCE FROM

TOTAL Frequency for Category: $21(0.21 \%)$

h. Neutral / Apathetic / Mixed Feelings

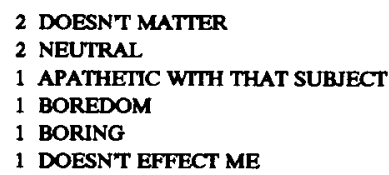

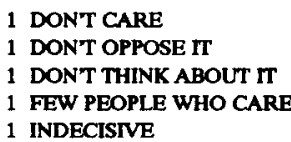

TOTAL Frequency for Category: $20(0.20 \%)$

i. Supervision / Responsibility

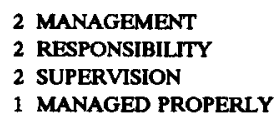

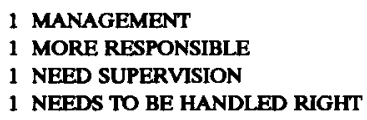

TOTAL Frequency for Category: $14(0.14 \%)$

\section{j. Public Figures}

$$
\begin{aligned}
& 3 \text { RONALD REAGAN } \\
& 2 \text { JERRY FALWELL } \\
& 1 \text { DR. TELLER }
\end{aligned}
$$

$$
\begin{array}{ll}
1 \text { GEORGE BUSH } \\
1 \text { GORBECHEV } \\
1 \text { MERYL STREEP }
\end{array}
$$

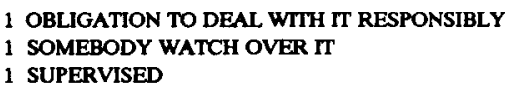

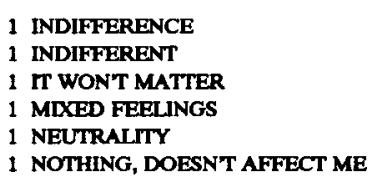

1 INDIFFERENCE

IT WONT MATTER

1 NEUTRALTTY

TOTAL Frequency for Category: $12(0.12 \%)$

\section{k. Fiction}

$$
\begin{aligned}
& 1 \text { 1950S PICTURE } \\
& 1 \text { A MOVIE I SAW ONCE } \\
& 1 \text { DAY AFTER-MOVIE } \\
& 1 \text { MOVIE }
\end{aligned}
$$

\author{
1 MOVIES \\ 1 REMINDS ME OF A MOVIE \\ 1 REPO MAN \\ 1 SCIENCE FICTION
}

\author{
1 NIXON \\ 1 OLLE NORTH \\ 1 REAGAN
}

TOTAL Frequency for Category: $11(0.11 \%)$

\section{Problem Avoidance}

2 DONT WANT TO THINK ABOUT IT

1 DONT LIKE TO THINK ABOUT IT

1 I TRY NOT TO
1 I WISH IT WASN'T NECESSARY 1 WSH WE DIDNT HAVE THEM 1 TRY NOT TO THINK ABOUT IT

TOTAL Frequency for Category: 9 (0.09\%) 
m. Inevitability

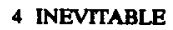

1 ETERNA

1 ETERNAL LIFE

\section{MISCELLANEOUS}

1 GONNA BE GONNA BE 1 ITS GOING TO HAPPEN

1 WERE GOING TO HAVE

TOTAL Frequency for Category: $8(0.08 \%)$

TOTAL Frequency for Category: $5(0.05 \%)$

o. O.K. If...

1 AS LONG AS IT IS HANDLED RIGHT

1 GOOD IF UNDERGROUND 1 OK IF AWAY FROM POPULATION

TOTAL Frequency for Category: $4(0.04 \%)$ 


\section{UNCATEGORIZED IMAGES}

5 NOTHING

4 EXPOSURE

4 LIFE

4 TIME

3 BREATHING

3 RECYCLE

2 CLAUSTROPHOBLA

2 COMMUNISM

2 CONSERVATION

2 CRIES

2 DUST

2 EFFECTS

2 GREEN

2 GREENPEACE

2 GROWTH

2 HELP

2 HIDE

2 HOSPITAI

2 LIGHTS

2 NO GROWTH

2 PEACE

2 PLANT

2 PROTECTIVE

2 RECYCLEABLE

2 RED

2 RUSSIANS

2 SCAPE GOAT

2 SHELTER

2 SIGNS

2 SPACE

2 SURVIVAL

2 TOO MANY

2 TREATMENT

2 UNREAL

2 WOULDNT WANT TO BE AROUND

1 12TH GRADE

1 17TH/WASHINGTON

11950 's

1 A BUNCH OF STUFF UNDERGROUND

1 A COP OUT

1 A LOT OF TALK ABOUT IT

1 A LOT OF TRAFFIC IN AND OUT

1 A LOT OF WORK

1 ABANDON

1 ABANDONED

1 ABANDONED MACHINERY

1 ACCESSIBILITY

1 ACCESSIBLE

1 ACTION

1 ADDRESS THE PROBLEM

1 AFFECTING LIVES

1 AFTERGLOW

1 AFTERMATH

1 AIR RAID

1 ALIENATOR

1 ALL ALONE

1 ALTERNATIVE FORMS OF ENERGY

1 ALTERNATTVE TO PROVIDE THAT POWER

1 AMOUNT

1 ANY REPOSTTORY

1 APS SHOULD PAY FOR IT

1 ATTACKS

1 AVAILABLE

1 BACKFIRE

1 BALD

1 BALDNESS

1 BARRELS, DEBRIS

1 BARROWS

1 BASE

1 BASEMENT

1 BATS

1 BEER

1 BEST FRIEND'S PARTY

1 BI- PRODUCT

1 BI-PRODUCTS

USE

1 BITHERS TOY
1 BIZARRE

1 BLASTING

1 BLIND

1 BLOWING IT UP

1 BLOWING THINGS UP

1 BLOWN OUT OF PROPORTION

1 BODY PARTS

1 BRAVE

1 BUDDIE PERCHETT

1 BUFFALO

1 CAMWAYS MANAGEMENT

1 CANT HELP ANYTHING

1 CANYON

1 CAPACTYY

1 CARE FOR WORKERS OF FACILITIES

1 CAULDRON

1 CHILDISH

1 CHILDREN (GENERATION)

1 CHINA LAKE-KIDS AFFECTED

1 CITY DEPRESSION

1 CLAUSTROPHOBIC

1 CLEARING

1 CLOSE TO AN OCEAN

1 CLOSED FAST

1 COAL MINE

1 COMING

1 CONSTRUCTION

1 CONSUMER

1 CONSUMER ADVICE

1 CONTAGIOUS

1 CONVERTED TO FUEI

1 CORE

1 COUNTRIES

1 COVERAGE PROPERLY

1 CPPP

1 CURRENT

1 CURTAILMENT

1 DEFACING

1 DEFINITE

1 DEFOLIATION

1 DENSE

1 DEPENDS ON CIRCUMSTANCES

1 DEPLETION

1 DEPOSTT

1 DESIGN OWN BETTER THEN ANYTHING EISE

1 DISARMAMENT

1 DISPERSION

1 DISPOSAL DEVICE

1 DISPOSAL UNIT

1 DO WTTH WASTE

1 DOG FOOD

1 DONT CAUSE PROBLEMS

1 DONT DESTROY COLORADO

1 DONT EDUCATE PEOPLE ABOUT IT

1 DONT THINK WE SHOULD WASTE ANY

1 DONT THROW WHERE THEY ARE

1 DONT WANT IN OPEN

1 DONE RIGHT

1 DOWNFAIL OF POPULATION

1 DRAINAGE

1 DUDE

1 EFFORT

1 EMOTIONS

1 EMPLOYEES

1 ENGINEERING

1 ENVIRONMENTAL HEALTH

1 ENVIRONMENTAL ISSUE

1 ENVIRONMENTALIST

1 ERUPTION

1 ESCAPE

1 EUROPE HAS LESS TROUBLE

1 EVACUATION PLANS

1 EVENTS

1 EVENTUAL EVACUATION

1 EVENTUALLY BECAME TOO COMMON

BODY WOULD MOVE

1 EVERYONE SHOULD BE INVOLVED

1 EXECUTION
1 EXISTING

1 FACT OF LIFE

1 FAD

1 FARM ANIMALS

1 FATIGUE

1 FELL FOR PEOPLE LIVING CLOSE TO IT

1 FENCING

1 FEUDAL

1 FIEID

1 FIELD CONTAINERS

1 FIEID IN GLASS

1 FINDING THE LOCATIONS

1 FRACTURE POINTS

1 FUEL

1 GAMBLE

1 GEOLOGICAL SURVEY

1 GERMANY-UNDERGROUND SYSTEMS

1 GETS BANNED

1 GETTING RID OF THE WASTE

1 GLANT GRANT

1 GOING TO GET FULL

1 GOLD SUITS

1 GOSH

1 GRAVEYARD

1 GRAY

1 GROUNDWORK

1 GROW/NG NEAR THEM DEAD THINGS

1 GUIDELINES

1 GUSTY

1 GUTTER

1 GUTTERS

1 HAIR

1 HARD TO DEFINE

1 HARD TO NOTICE IT'S THERE

1 HARRY REID

1 HECTIC

1 HEIGHTS

1 HIDING

1 HIGH VOLTAGE

1 HISTORY

1 HOMELESS PEOPLE

1 HOPING THAT WE CAN GET RID OF IT

1 HOSPITALS

1 HOT SPOTS

1 HUGE GRAVEYARD

1 HUGE WELIS

1 HYPERTENSION

1 I HOPE IT DOESNT BLOW UP

1 I HOPE IT IS IN A MOUNTAINOUS AREA

1 I HOPE ITS PUT TOGETHER WELI

1 I WONDER WHY WE HAVE IT

1 I'D VOTE TO HAVE IT CLEANED UP

1 IMMEDIATE ATTENTION

1 IMPROPER INFO

1 INHABITABLE

1 INSECTS

1 INSENSITIVE

1 INSIGNIFICANT

1 INSULATION

1 INTEX

1 INVESTIGATION

1 ION

1 IRON

1 ISLAND

1 IT'S A POSSIBILTTY

1 JAPANESE

1 JUST DO IT

1 KEEP DENSELY POPULATED

1 KEEP OUT OF SIGHT

1 KENNEIMAN CTTY

1 LACK

1 LAND ELIMINATION

1 LARGE COMP

1 LAVA

1 LAWSUITS, BIG ONES

1 LAX CONIROL

1 LEAVE

1 LENGTH 
APPENDIX - Page 28

\begin{tabular}{|c|c|c|}
\hline 1 LESS GROUND & 1 OVERALL USES HELPFUL & 1 SHOVED \\
\hline 1 LESS PEOPLE & $1 \mathrm{OWN}$ & 1 SKEILETONS \\
\hline 1 LIABILITY & 1 PATRIOTTSM & 1 SKIN \\
\hline 1 LIBERAL & 1 PEACE & 1 SOCIETY \\
\hline 1 LIBERALS & 1 PEACE WILL OVERCOME & 1 SOME FACILITY TO HOUSE THE PEOPLE \\
\hline 1 LIMTTED USE & 1 PEOPLE DONT KNOW IT'S THERE & 1 SOMETHING NEW \\
\hline 1 LIVE WITH IT & 1 PEOPLE REIATIONS & 1 SOMETHING SHOULD BE DONE ABOUT IT \\
\hline 1 LOCATED IN A MILDLY POPULATED AREA & 1 PEOPLE WONT TRY SOMETHING DIFFERENT & 1 SOMETHING THATS FUNNELED \\
\hline 1 LONELY & 1 PERMEATES & 1 SORRY WE GOT NO OTHER \\
\hline 1 LONG TERM COMMITMENTS & 1 PLACE & 1 SOVIET \\
\hline 1 LONG WAIT & 1 PLANNING & 1 SPACE \\
\hline 1 LOOKS LIKE MY NEIGHBORHOOD & 1 PLANTATION DYING & 1 SPACE IT WOULD TAKE \\
\hline 1 LOSS OF SPACE & 1 POOR KIDS & 1 SPEAKERS \\
\hline 1 LOTS OF SPACE FOR SOMETHING & 1 POOR SOURCE OF ENERGY & 1 STABLE \\
\hline 1 LOTS OF TIME & 1 POSSIBILITY FOR HUMAN & 1 STATES \\
\hline 1 LOUD & 1 POSSIBLE & 1 STEAM \\
\hline 1 LOW LEVEL IS NOT A CONCERN & 1 POTENTLALLY & 1 STERILE \\
\hline 1 MAINTENANCE & 1 POVERTY & 1 STOCKPILE \\
\hline 1 MAKING IT INTO TOURIST PLACE & 1 PRACTICAL & 1 STOP THE CAUSE \\
\hline 1 MALFUNCTIONING POSSIBILITIES & 1 PRAIRIE & 1 STOPPAGE \\
\hline 1 MANMADE & 1 PREJUDICE & 1 STORAGE OF DEADLY FUMES \\
\hline 1 MASKS & 1 PREPARATION & I STORAGE OF NUCLEAR WASTE \\
\hline 1 MATERIAL & 1 PREPAREDNESS & 1 STORE STUFF \\
\hline 1 MELTING & 1 PREVENT CONTAMINATION & 1 STORING NUCLEAR WASTE \\
\hline 1 MELTING POT & 1 PREVENT NUCLEAR ACCIDENT & 1 STRESS \\
\hline 1 MIKE BOSMAN & 1 PRIVATE & 1 STRESS POINTS \\
\hline 1 MILL & 1 PROBABLY HAS TO BE ADDRESSED & 1 SUBSTTTUTE NUCLEAR \\
\hline 1 MINING AREA & 1 PROBABLY HAVE THEM AND DONT KNOW IT & 1 SUICIDAL \\
\hline 1 MDXED & 1 PROBLEM IN MINNESOTA & 1 SUICIDE \\
\hline 1 MODERN & 1 PROBLEM SOLVING & 1 SUMMTT MEETING \\
\hline 1 MODERN TIME & 1 PROCESSED FOOD & 1 SUN \\
\hline 1 MOLDY & 1 PRODUCERS & 1 SUPER COLLIDER \\
\hline 1 Moss & 1 PROLIFERATION OF HOSTILITIES & 1 SUPERFUND \\
\hline 1 MOVE THEM & 1 PROPER & 1 SURPRISE \\
\hline 1 MOVEMENT & 1 PROPER DISPOSAL & 1 SURROUNDS US \\
\hline 1 MY HOUSE & 1 PROPERTY & 1 SWAMPS THAT ARE DARK \\
\hline 1 MYSTERY & 1 PUSHOVERS & 1 TAKING ADVANTAGE OF ITS LOCATION \\
\hline 1 NATION & 1 PUTATION & 1 TAKING CARE OF IT \\
\hline 1 NATIONAL & 1 QUALIFIED PEOPLE & 1 TAKING OUT SPACE \\
\hline 1 NATURE WILL HOPEFULLY TAKE CARE OF IT & 1 QUALTY & 1 TANGWANDA \\
\hline 1 NEGATE & 1 RACED & 1 TEMPORARY \\
\hline 1 NEW & 1 REACTION & 1 TEST TUBE \\
\hline 1 NEW WORLD & 1 REACTIONARIES & 1 THERMO PLANTS \\
\hline 1 NEWS & 1 RED LIGHT & 1 THOUGHTLESS \\
\hline 1 NIGHT & 1 RED SKY & $1 \mathrm{TO}$ \\
\hline 1 NO EFFECT & 1 REDESIGN & 1 TO POINT WHERE IT IS PART OF LIFE \\
\hline 1 NO HOPE FOR SOLAR & 1 REDUCTION & 1 TOO CLOSE \\
\hline 1 NO MATTER HOW THEY USE IT & 1 REJECTED & 1 TOO CLOSE TO HOME \\
\hline 1 NO MORE ROOM INSIDE & 1 REJECTION & 1 TOO MUCH \\
\hline 1 NO TRESPASSING SIGNS & I REPOSITORY & 1 TOUCHES EVERYTHING \\
\hline 1 NO USE & 1 REQUIREMENT & 1 TOXIC ADVENTURE \\
\hline 1 NO WORK & 1 RESPECT & 1 TRASH DOWN IN PLACE \\
\hline 1 NON-PEACE & 1 RESTRICTION & 1 TRAVEL \\
\hline 1 NON-PRODUCTIVE & I RETALIATION & 1 TREATIES \\
\hline 1 NONE & 1 RODS & 1 TRYING TO GET UNDER CONTROL \\
\hline 1 NOSE & 1 RUBBER SUIT & 1 TUTONIUM \\
\hline 1 NOT CLOSE TO WATER & 1 RUNNING AWAY & $1 \mathrm{US}$ \\
\hline 1 NOT ENOUGH & 1 RURAL & 1 UGLY LANDSCAPE \\
\hline 1 NOT ENOUGH SAFE PLACES & 1 RUST & 1 UNFORTUNATELY \\
\hline 1 NOT EXPERIENCED & 1 RUSTING 55 GALLON BARRELS & 1 UNIFORMED \\
\hline 1 NOT MUCH OF ANYTHING & I RUSTY & 1 UNIFORMITY \\
\hline 1 NOT NATURAL & I SANITATION & 1 UNIMPOSING \\
\hline 1 NOT SUFFICIENT & 1 SATURATION OF SOILS & 1 UNIVERSITY OF ARIZONA \\
\hline 1 NOT TAKEN CARE OF & 1 SAVE ENERGY & 1 UNOBTRUSIVE STORAGE \\
\hline 1 NOT THE WAY OF THE FUTURE & I SAVE MY LIFE & 1 UNTOLD LIFE EXPECTANCY \\
\hline 1 NOT TOO DANGEROUS & 1 SAVING MONEY & 1 USING THE WASTE FOR PRACTICAL PURPOSES \\
\hline 1 NOT WANT TT TO DAMAGE ANYTHING CLOSE BY & 1 SCARCITY & 1 UTAHONA \\
\hline 1 NOT WEILL REGULATED & 1 SCAVENGE & 1 VALLEY \\
\hline 1 NOT WORTH TAKING CHANCES ON THE PEOPLE & $1 \mathrm{SCHOOL}$ & 1 VALUE \\
\hline 1 NOTHING COMES TO MIND & 1 SCHOOL AFFECTED & 1 VERY LITLE VEGETATION \\
\hline 1 NOWHERE & 1 SEGREGATED & 1 VULNERABLE \\
\hline 1 OIL SPILL & 1 SELF DESTRUCTIVE & 1 WASTE HAZARDS \\
\hline 1 ON ALERT & 1 SEPARATE & 1 WASTE OF LIFE \\
\hline 1 OPEC & 1 SHARED & 1 WASTE REDUCTION \\
\hline 1 OPTIONAL & 1 SHEER POINTS & 1 WASTE THE STATE OF OHIO \\
\hline 1 ORGANIZED & 1 SHIELDING & 1 WASTE TIME \\
\hline 1 OUT OF IT & 1 SHIP AWAY & 1 WASTED \\
\hline 1 OUT OF SIGHT & 1 SHORT RUN & 1 WATER CONTAINER \\
\hline 1 OUT OF SIGHT, OUT OF MIND & I SHOULD BE LOCKED & 1 WATER SEEPAGE \\
\hline 1 OUT OF WAY & 1 SHOULDNT BE ALONE ANYWHERE & 1 WATER, DRY SURROUNDING \\
\hline 1 OVER-RATED & I SHOULDNT BE FEAR & 1 WAY OFF \\
\hline
\end{tabular}


APPENDIX - Page 29

1 WE CAN DO IT IF WE PAY FOR IT

1 WHAT CAN WE DO TO ELIMINATE IT

1 WE GOT OURSEL VES INTO IT/ULTIMATE WASTE 1 WHAT CITY

1 WE HAVE TO PICK A PLACE TO HAVE IT

1 WHAT DO YOU

1 WHAT DO YOU WANT TO KNOW

1 WE'LL BE DEAD/TAKING OVER POPULATION 1 WHERE THEY PUT THE WASTE

1 WE'RE NOT FINDING A BETTER SOLUTION

1 WHITE SAND

1 WELL BUILT

1 WELL BUILT INCINERATORS

1 WEST

1 WHO CLEANS UP MESS

1 WHOSE ABLE TO HANDLE IT

1 WIFE

1 WHAT CAN I DO

1 WFE

1 WIRES ABOVE GROUND

1 WISH WASNT

1 WONDER

1 WORLDWIDE

1 WOULD NOT WANT TO LIVE

1 WOULD THEY GO OFF

1 wow

1 YELLOW SUITS 